WILD FLOWERS

AND TREES

OF COLORADO

RAMALWT

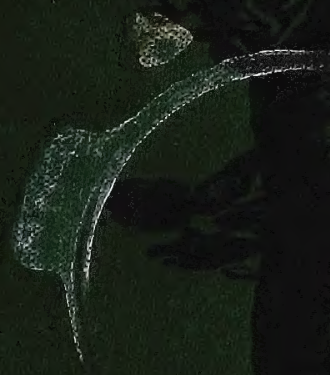


QK 150.Rornell Unlversity Llbrary

Wild flowers and trees of Colorado.

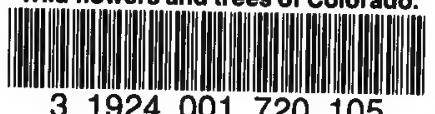

$\begin{array}{llllll}3 & 1924 & 001 & 720 & 105\end{array}$ 


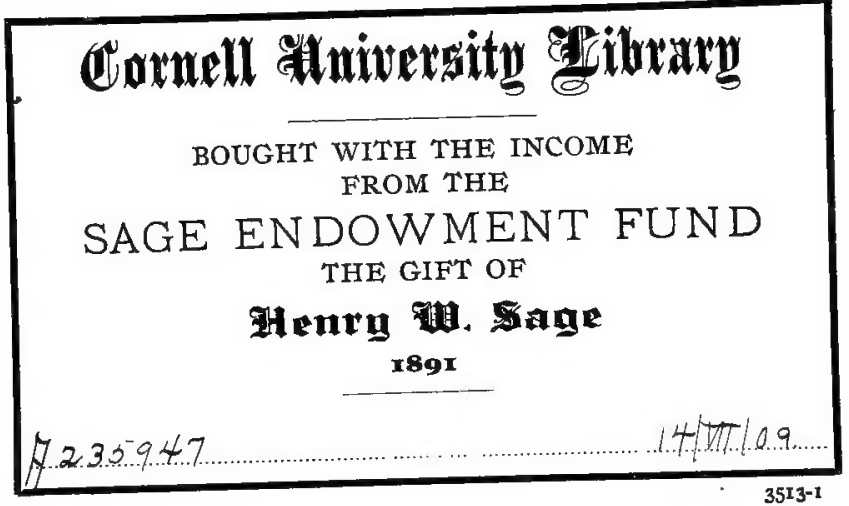

RETURN TO

\section{ALBERT R. MANN LIBRARY}

ITHACA, N. Y. 


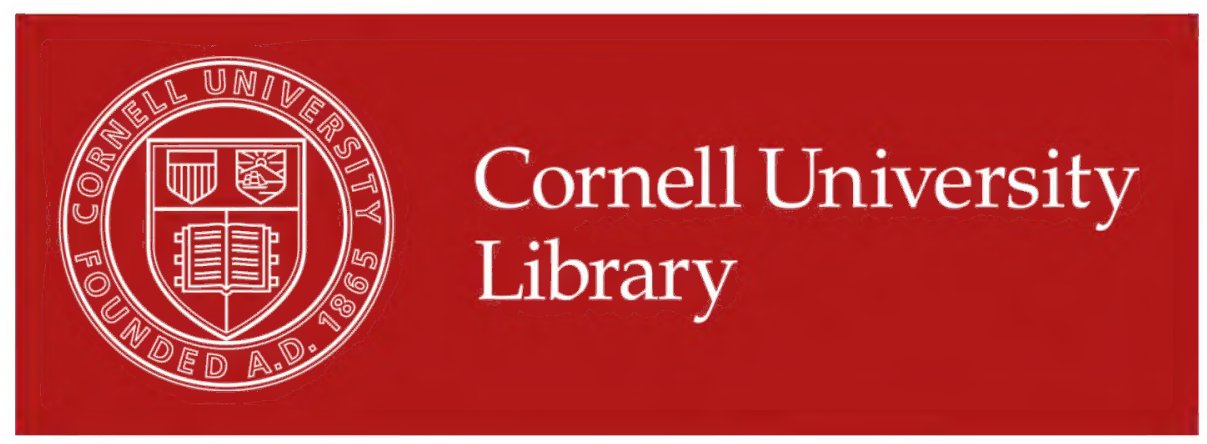

The original of this book is in the Cornell University Library.

There are no known copyright restrictions in the United States on the use of the text.

http://www.archive.org/details/cu31924001720105 





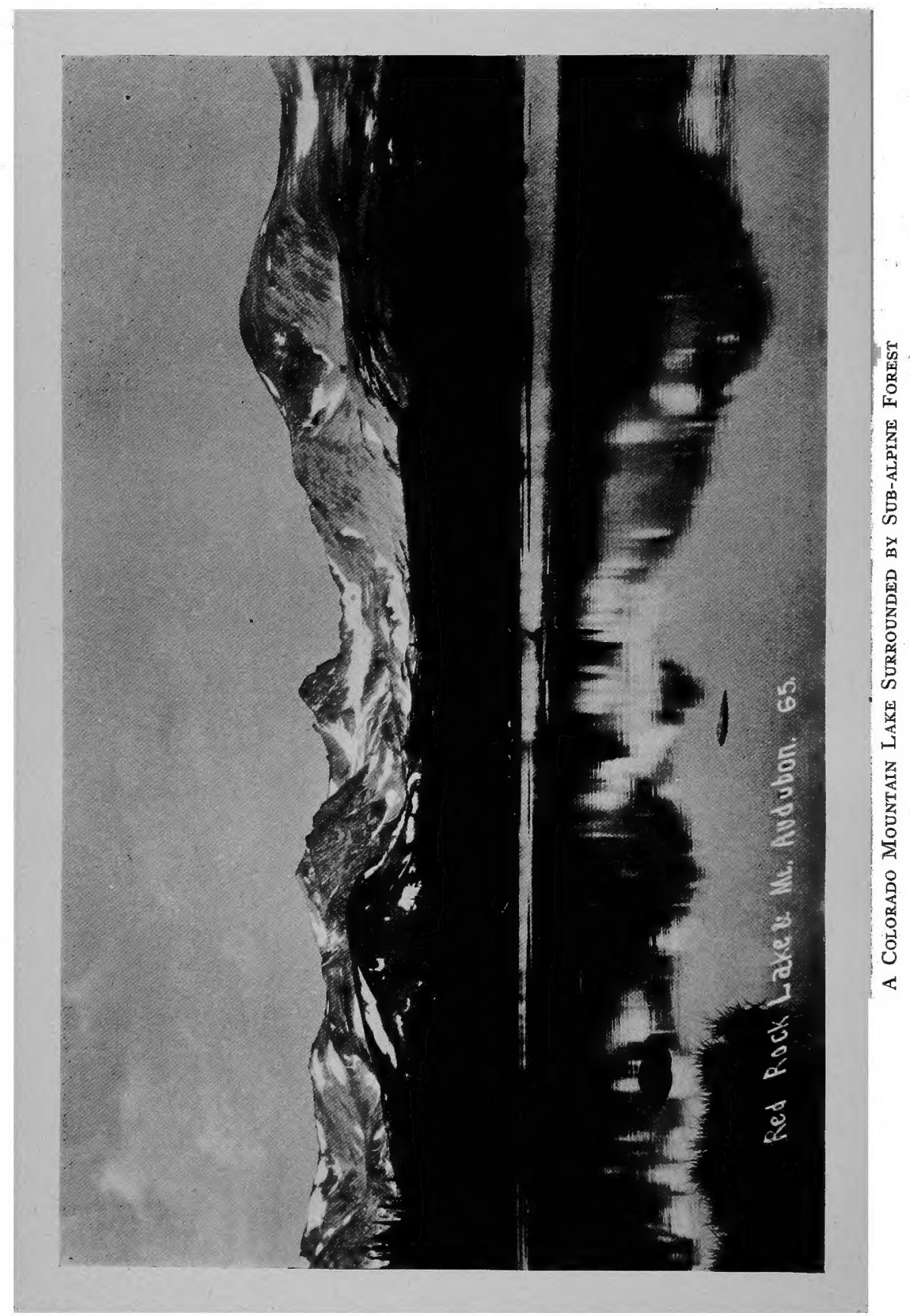






\title{
WILD FLOWERS AND TREES OF COLORADO
}

\author{
By \\ Francis Ramaley, Ph.D. \\ Profensor in the University \\ of Colorado
}

Boulder, Colorado

A. A. Greenman, Univereity Book Store 1909 


\section{QK \\ 150 \\ RITW \\ A.233947}

\section{Copyright Igog}

By Francis Ramaley 


\section{PREFACE}

This little volume is intended as an introduction to Colorado plants. It is not the result of book study but of many summers' work in forest and meadow, on alpine height and level plain.

The first part of the book is a short essay on the plants of Coloradotheir habits, distribution and relation to altitude. In the short compass of the book it is possible to describe only a few of the flowering plants of the state but the examples chosen are of the most interesting species from different altitudes.

- Trees, the author believes, are the best plants to begin with in a study of vegetation. Hence, he has given, in addition to drawings of many of the species, rather full accounts of some of the more important ones. Keys are arranged for the determination of all native trees of the state. By the use of these it becomes possible to recognize with ease the different species met in a-mountain journey or during a trip on the plains.

Boulder, Colo.

March, Igog 



\section{COLORADO WILD FLOWERS ${ }^{x}$}

\section{Plants and Their Distribution}

There are more different species of wild flowering plants in Colorado than in any state of the Union except California, the number thus far recognized being about 3,000 . It is largely because of the varied conditions of climate that so many plants are able to grow within the borders of the state. A single small area, such as Boulder County, has more different climates than could be found in a whole state such as Pennsylvania or Illinois.

Besides the climatic differences, which are chiefly the result of altitude, an important feature which makes Colorado so rich in plant forms is its central location. Passing through the state is the continental divide which is the westward limit of extension for eastern plants, and the eastern boundary for western plants. Botanically speaking the state may be said to lie half way between the Atlantic and Pacific, although geographically it is somewhat nearer the Pacific.

In the western half of the state the plants are such as occur also in Utah, Idaho and Nevada, while on the plains to the east of the continental divide the plants are related to those of Nebraska and Kansas. The flora of the higher mountains is much the same on the two sides of the divide.

Probably the easiest way to gain an idea of the Colorado flora is to consider in order some of the conditions under which plants grow. The simplest classification is made according to altitude. Changes in altitude mean differences in climate and, because of this, differences in the trees and herbs. It is possible to recognize a series of zones or belts of vegeta-

s There is no popular work of any kind dealing with Colorado plants. The author has in preparation an extended work, which may prove useful. Only one technical book of wide scope has been published in recent years, viz., RyDserg's Flora of Colorado, which may be obtained from the Director of the Experiment Station, Colorado Agricultural College, Ft. Collins. Professor Aven Nelson, of the University of Wyoming, will soon have ready a manual of Rocky Mountain Botany. 



\section{CONTENTS}

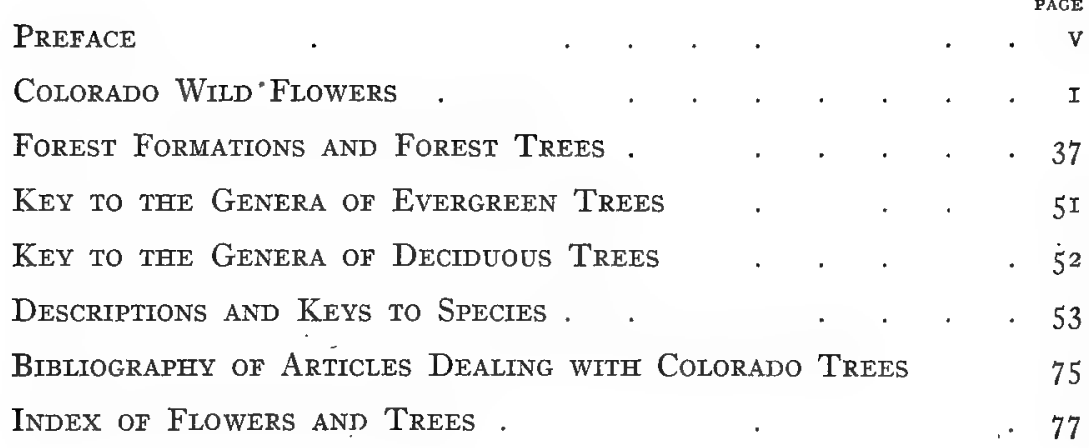




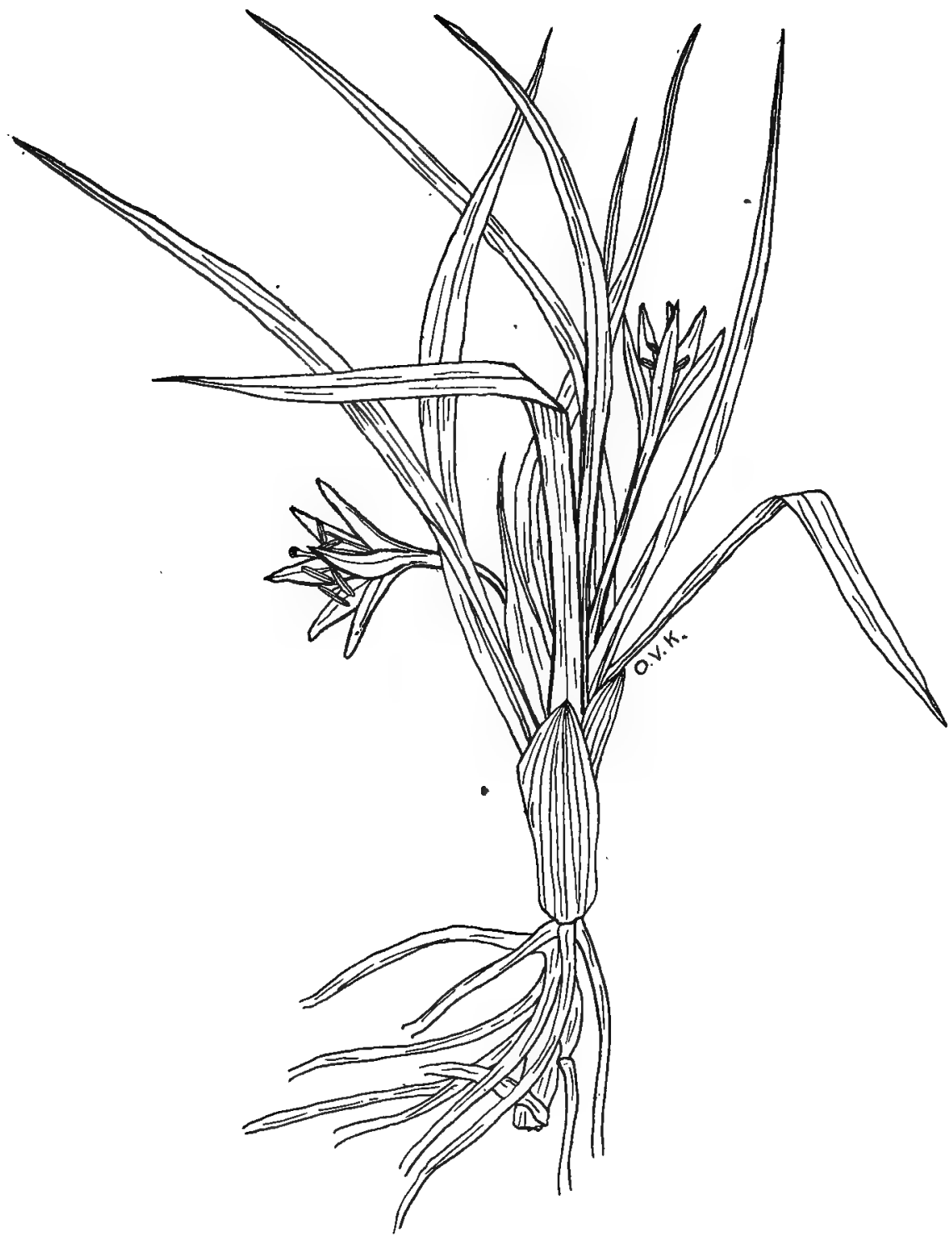

Frg. I.-SAND LILy (Leucocrinum montanum)

Abundant on the plains in early spring; occurs sparingly in the foothill and montane zone. The delicate white flowers resemble somewhat those of Narcissus. (Two-thirds natural size.) 
tion which, extending from the lower altitudes to the highest points, are as follows:

I. Plains zone-treeless, except along streams, dry in summer but with a profusion of handsome flowers in the moist months of spring.

2. Foothill zone-scattered trees; rock pines, pinyons, oaks, etc. The flowering herbs are numerous and remain in blossom longer than do those of the plains. The climate resembles that of Iowa and northern Illinois but is drier.

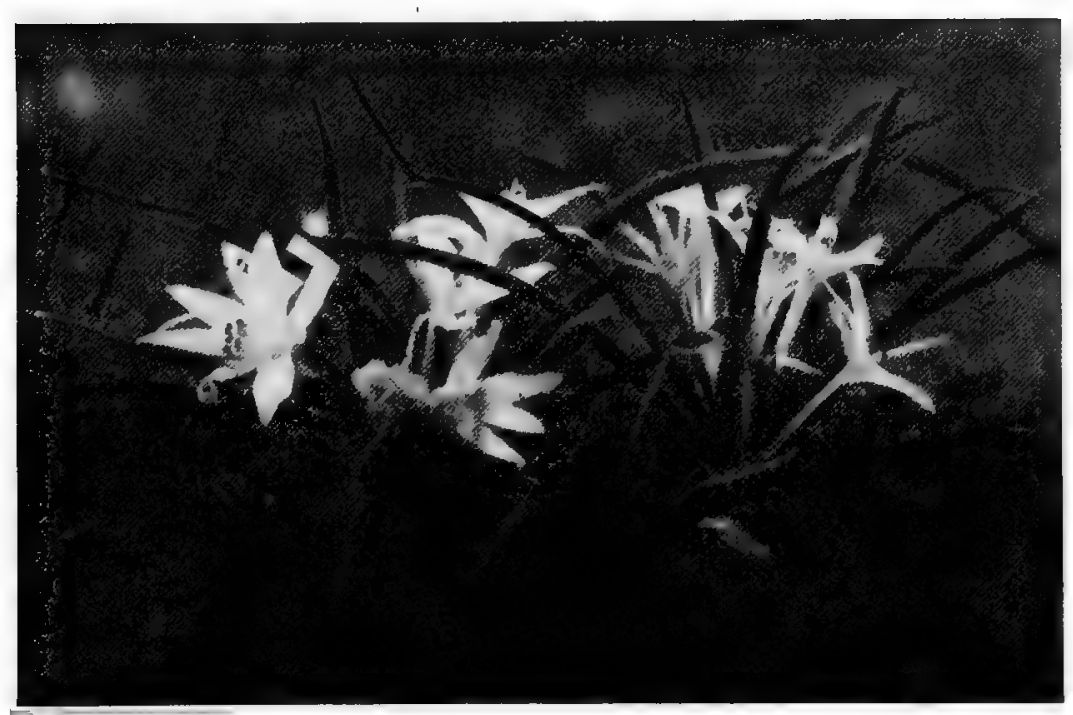

Fig. 2.-A Group of Sand Lities

3. Montane zone - chiefly forests of lodgepole pine or, in southern Colorado, Douglas spruce, white fir and some rock pines; aspens are abundant. Here are many beautiful flowering plants which do not extend down to the lower altitudes of plains and foothills. The climate resembles that of New England but winters are more mild. 4. Sub-alpine zone-chiefly forests of Engelmann spruce. The flowering herbs are not so numerous as in the lower zones but are very 


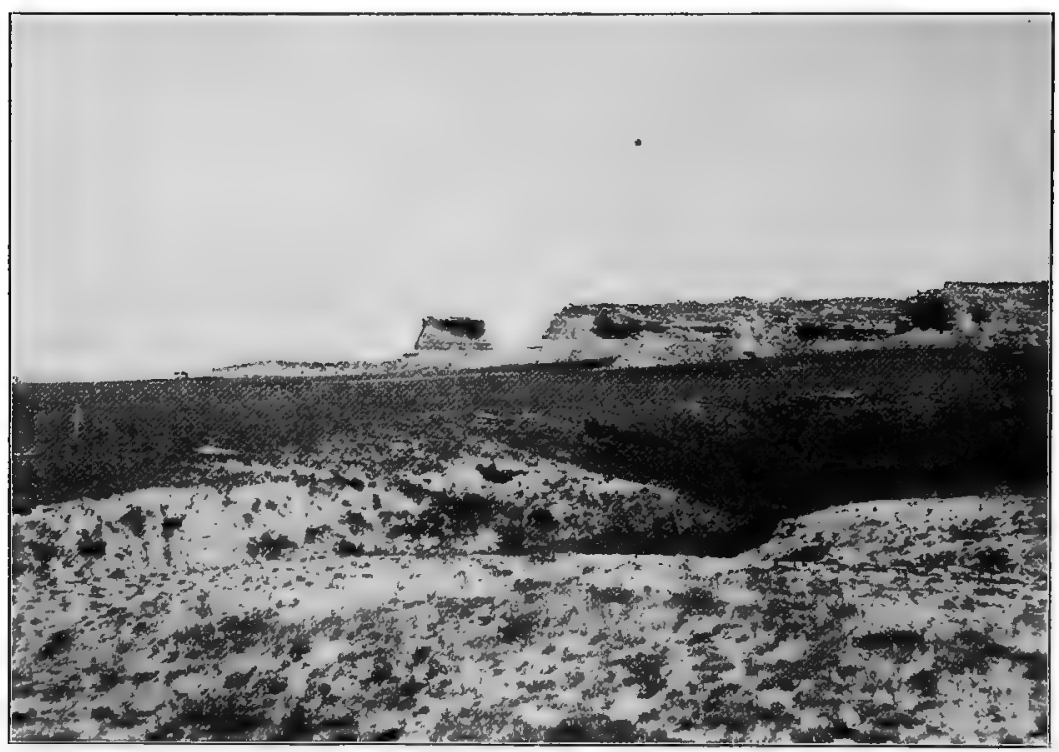

Fig. 3.-Gullies and Bluffs of the Plains Region

It is only in the spring that any number of wild flowers can be found here. The summer months are hot and dry.

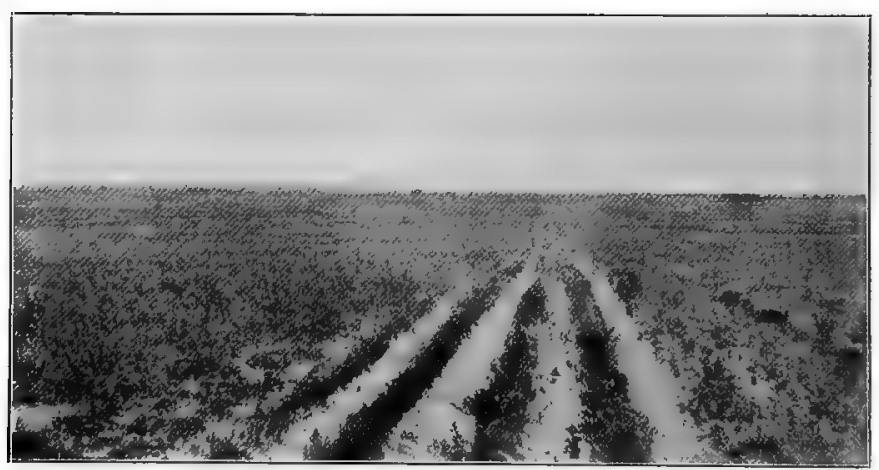

Fig. 4.-Level Area in the Plains Regron

. Grasses and flowering herbs form a conspicuous vegetation-cover in spring. 
handsome. There are many lakes and ponds. The climate resembles that of Hudson's Bay.

5. Alpine zone-above the limit of tree growth. Flowering herbs are numerous; those in drier situations are small and matted with a pro-

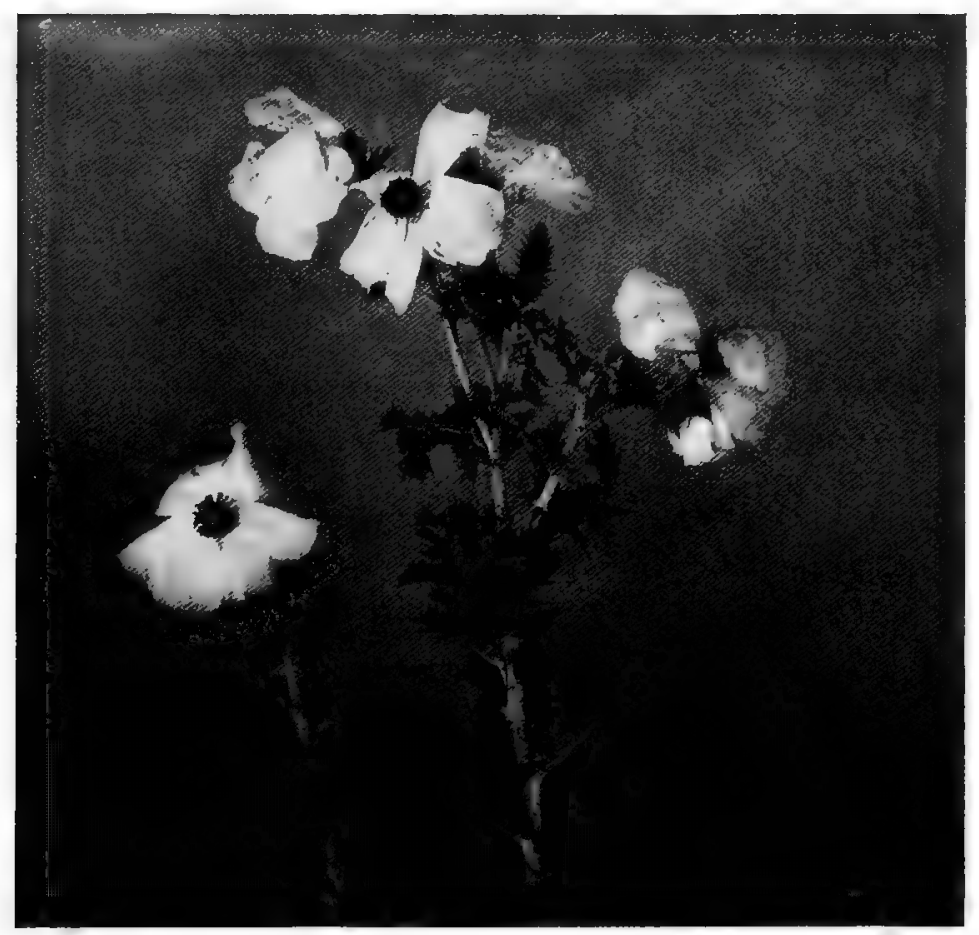

FIG. 5--PRICKLy POPPY (Argemone intermedia)

A tall, coarse plant with large white flowers and a sticky, yellow juice. Common along roadsides and railway tracks of the plains region, seldom extending any distance into the foothills. (One-sixth natural size.)

fusion of brightly-colored flowers. The climate is very cold, summers are short and winters long.

In each of the zones named above it is possible to recognize a great many sperial kinds of plant formation depending on soil-moisture, shade 
and other factors. Thus the flowering plants of a moist, shaded gulch are not the same as those of a dry, sunny ridge even at the same altitude, and great differences are seen between the plants which fringe an irrigating ditch and those that border a dry country road.

The limits of the present account will not permit a discussion of the

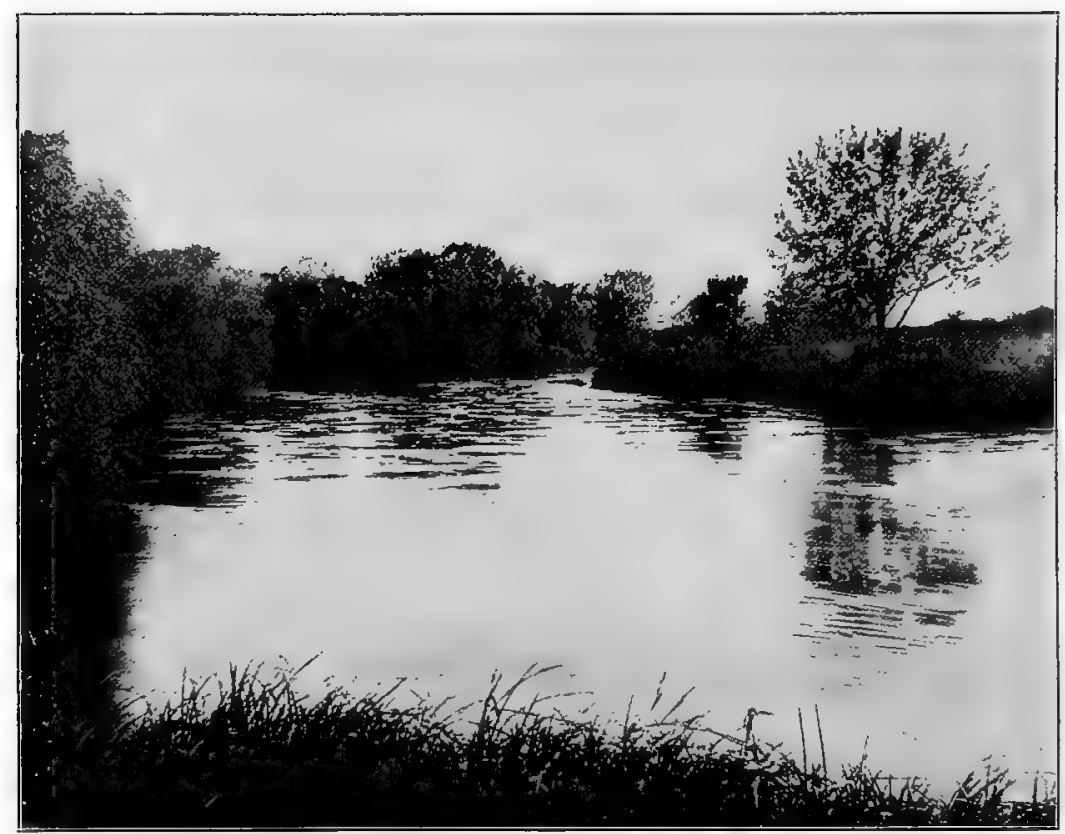

Fig. 6.-View on the Platte River near Greetey, Colo.

A narrow belt of forest extends along the river bank. The principal trees are broadleaf cottonwoods, box-elders and alders.

plants of all the different locations. It will only be possible to call attention to a few of the most interesting facts in regard to the relation between altitude and plant life and to show by the use of illustrations some of the more striking or notable flowering herbs of the different plant zones. 


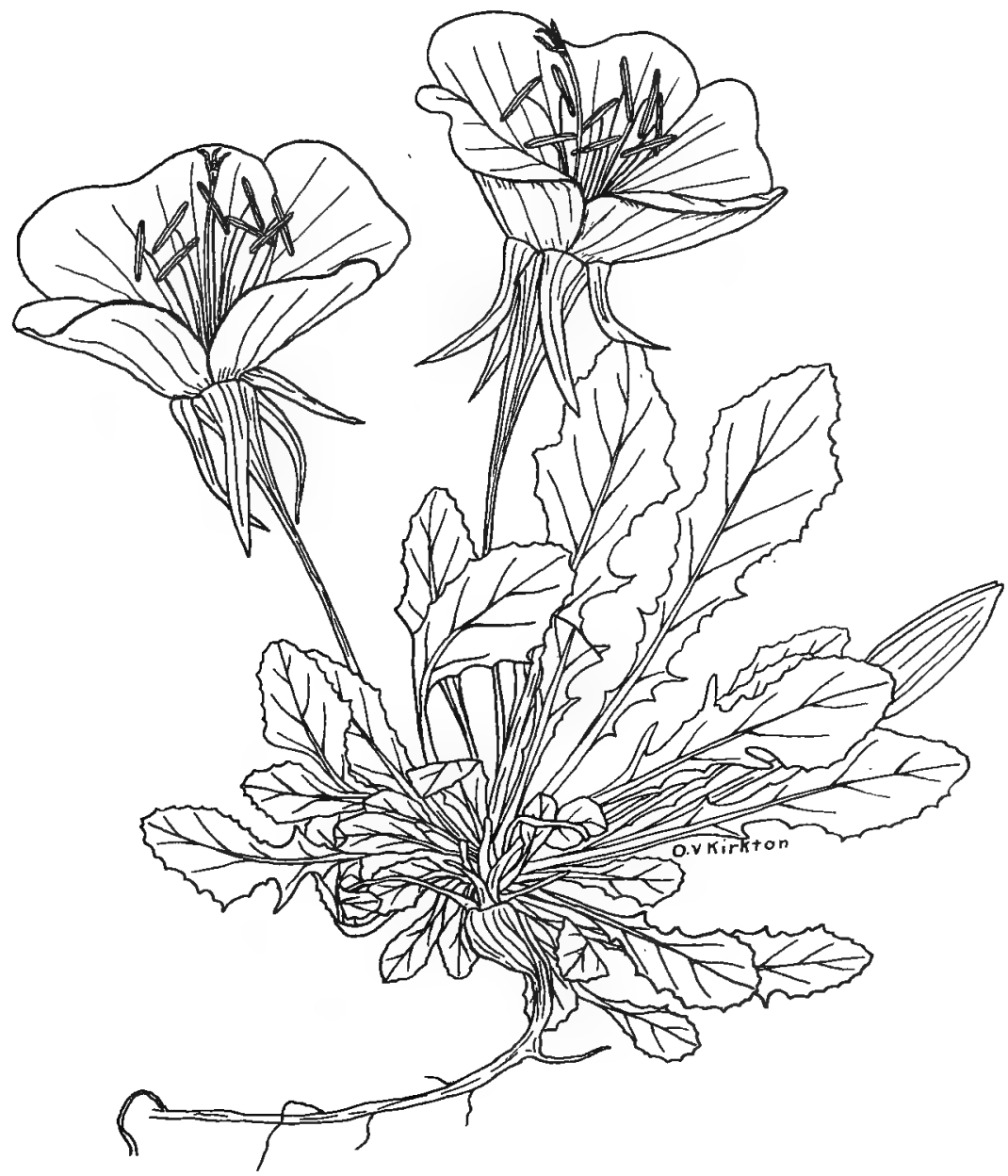

Fig. 7.-Evening Primrose (Pachylophus caespitosus)

There are many different kinds of evening primroses in Colorado, most of them occurring on the plains but some extending to the foothills. They often fill up abandoned fields after the manner of dandelions, blooming profusely in late spring or early summer. This particular species has pink flowers, but some kinds are a deep yellow and others are white. (One-half natural size.) 
Altitude, Climate and Plant Life

Plants of spring and autumn are very different. Early in the year many species "come into blossom which require some considerable

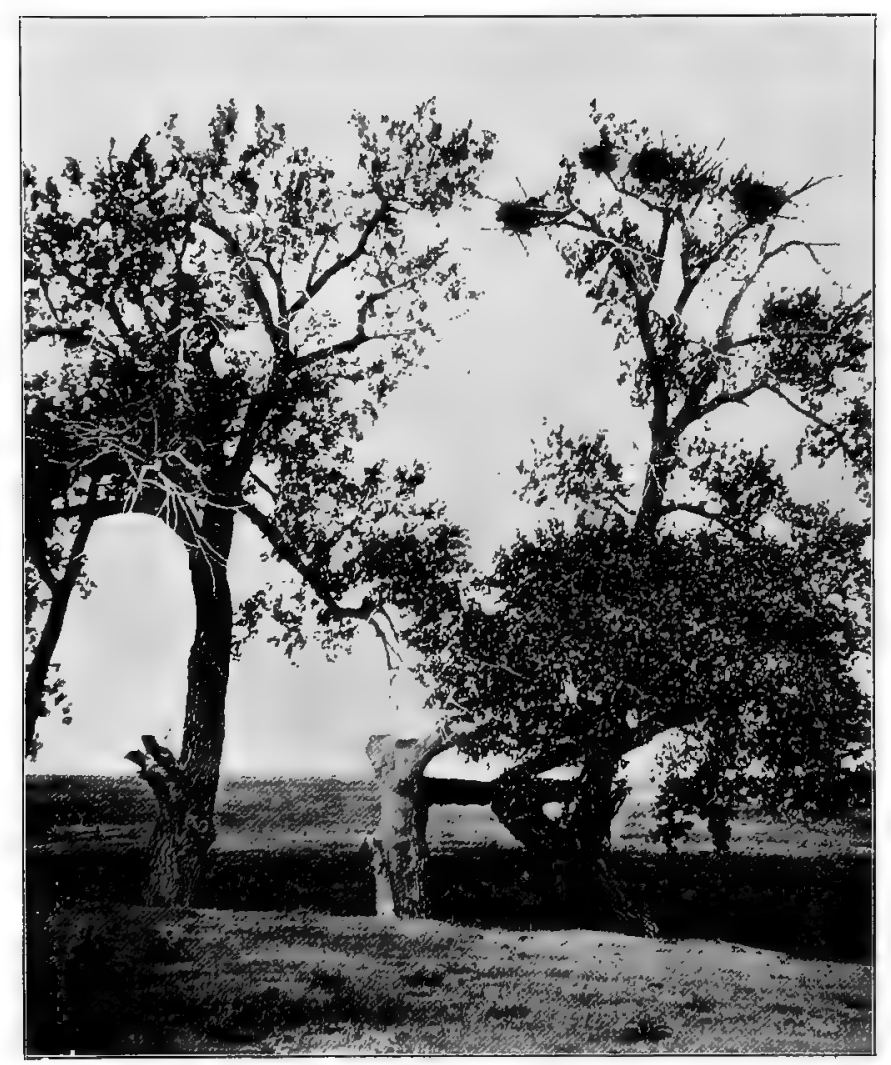

Fig. 8.-Broadleaf Cottonwoods along a Small Creek

This is a common type of scene on the great plains of eastern Colorado. Water courses . may be recognized miles away by the presence of straggling cottonwoods.

amount of moisture. The later-blooming flowers are those which are able to withstand dryness. After June there is very little rain in the plains region so that the ground becomes parched and dry. Usually in 


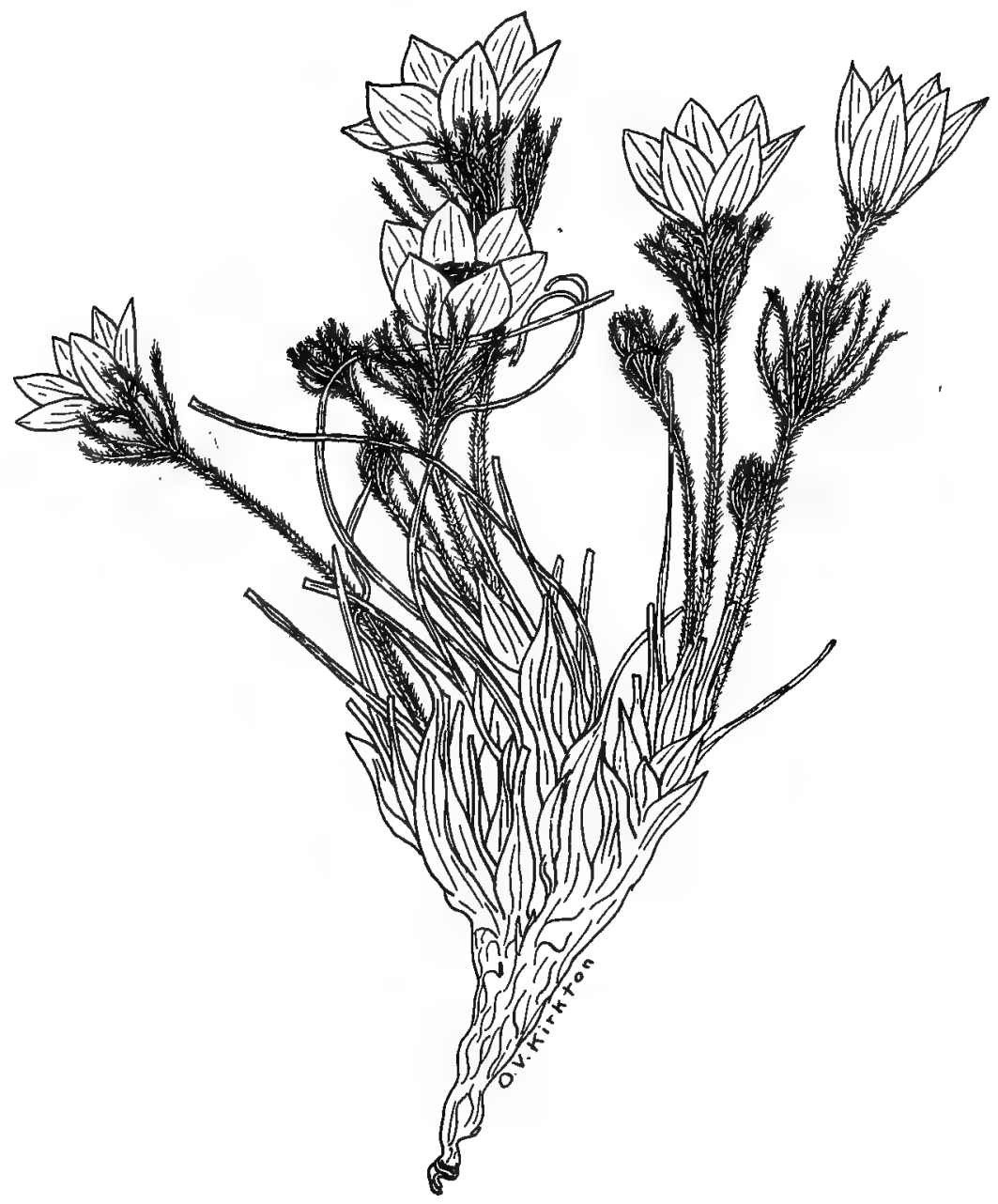

Fig. 9.-PASQue Flower (Pulsatilla hirsuitssima)

A spring-blooming plant very common in the foothills and sparingly distributed in the montane and higher zones. The flowers are light blue or lavender in color with a woolly circle of bracts on the flower stalk. The leaves appear after the flowers have faded. In Colorado this plant is frequently called "Anemone." (One-half natural size.) 
autumn there are few species in blossom except such coarse plants as surflowers and their relatives.

In mountain districts there are showers throughout the summer and so there is a continuous succession of flowers. Many of the plants which belong more properly to the montane zone occur also in the foothills

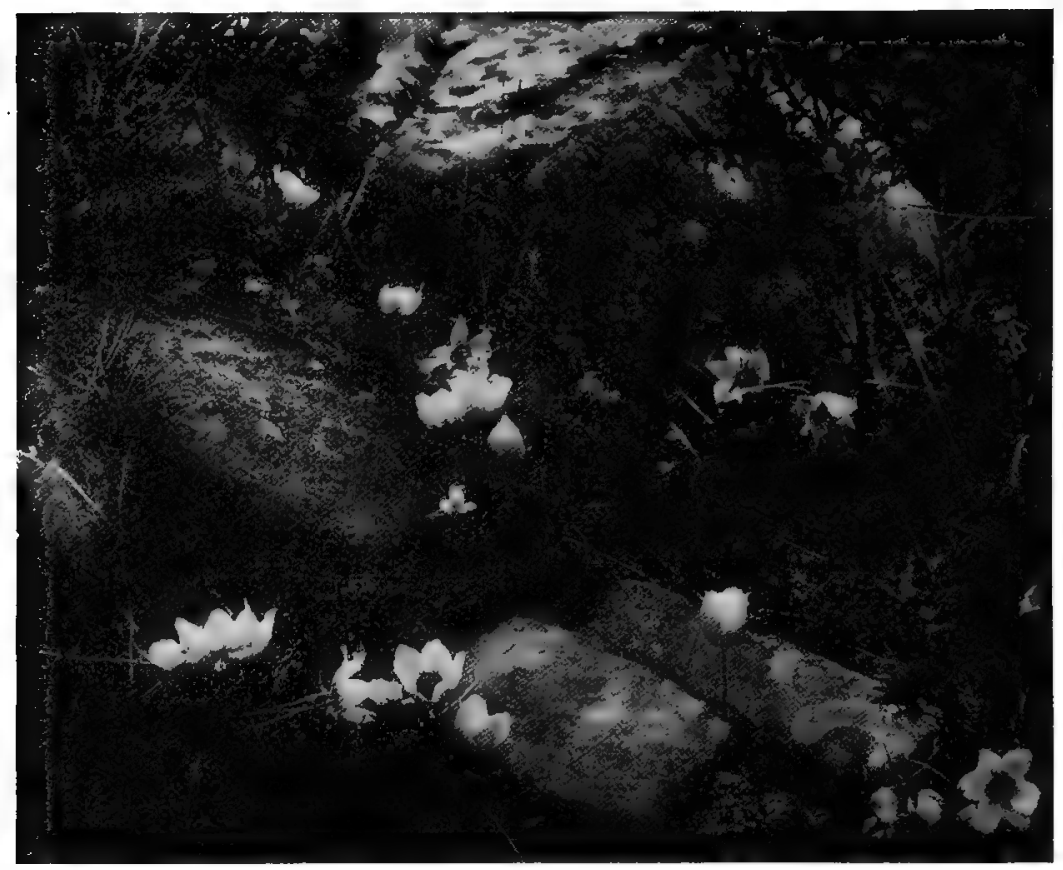

Fig. IO.-PASQUe Flowers ("Anemones")

where they first come into blossom. A week or two later they are in full bloom in their proper habitat. A few weeks later than this, with the general warming up of the summer a few specimens may be found in the sub-alpine districts.

Unless the differences in climate which may be recognized at different altitudes are constantly kept in mind it is impossible to understand the flora of a mountain region. With each thousand feet additional 
altitude there is a lowering of temperature to the extent of about three degrees Fahrenheit so that if the people in Denver are fanning themselves and trying to keep cool in a temperature of eighty in the shade, the camper or fisherman up at Tolland will find it cool and pleasant for strenuous exercise, since he is 4,000 feet higher and is enjoying a tempera-

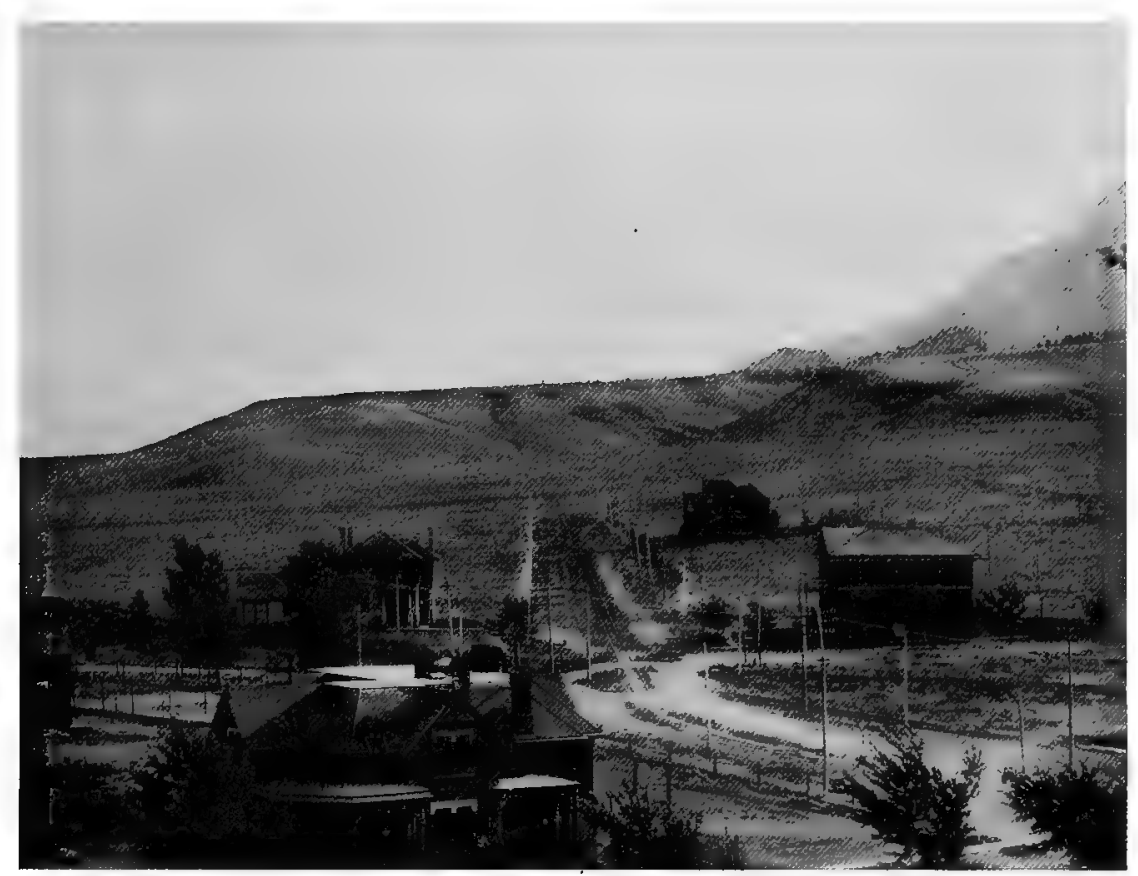

Fig. it.-Mesas near Boulder, Colo.

The mesas are flat-topped hills which extend out, peninsula-like, to the plains. Next to the mountains the mesas are covered with pines while toward the plains they are as treeless as the plains themselves.

ture of sixty-eight. This difference of temperature has its effect on the plant population. Indeed there are very few wild plants at Denver which also grow wild at such an altitude as that of Tolland.

Differences observed in regard to plants of the mountains which distinguish them from the plains species are generally ascribed to "alti- 
tude" in a very loose way. It is worth while finding out what this really means. To most people thinness of the air is the first thing thought about in connection with high mountain districts. It makes breathing difficult and a person is soon "winded" by slight exertion. But this

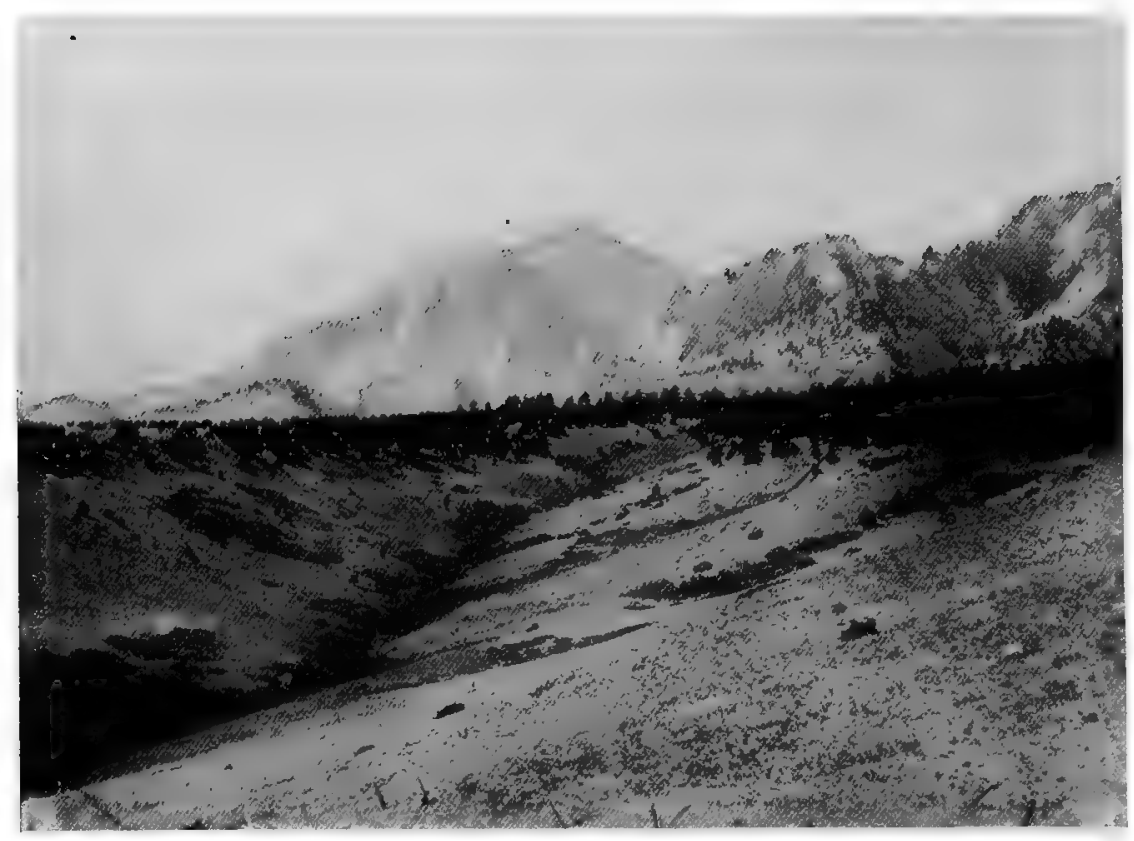

Fig. I2.-Vegetation of the Mesas

The view shows the western part of two mesas next the foothills. Pine trees form an open forest on the top of the mesa while the sides are bare. In the gulch there are thickets of willow and thornapple.

thin air does not disturb plants. Indeed there have been experiments made upon plants in laboratories which show that they grow very well in glass cases when a part of the air is removed and make a larger and faster growth than when under ordinary conditions. Hence, it is apparent that the dwarfing of high-altitude plants is not due to rarity of atmosphere. 
As is well known, plants reach greatest luxuriance in the tropics where, in addition to high temperature, there are to be found wet soil and damp atmosphere. On mountain summits of the Rockies the opposite conditions prevail. The air temperature is low every night in the year. Rainfall is not great. The soil is never warmed except for a few inches at the top. This cold soil makes the roots sluggish

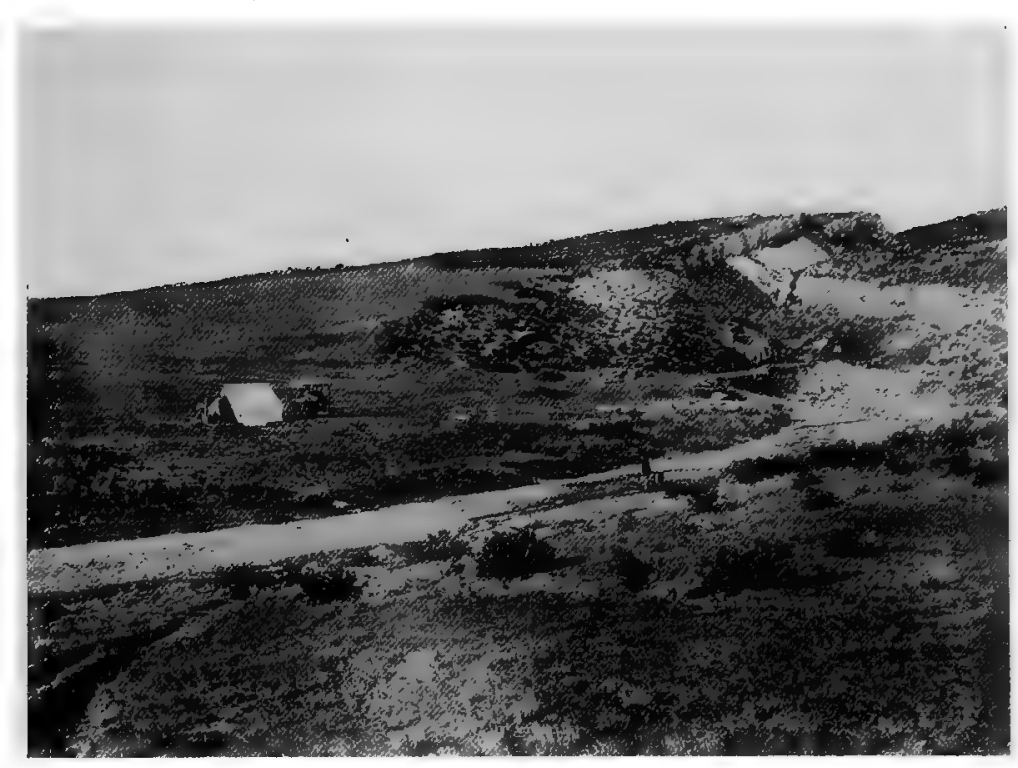

Fig. I3.-Rock Ridge Country of Northern Colorado

In this part of the foothill region the valleys have a dense covering of long grass while the ridges support shrubs of mountain mahogany and scattered pines.

in their work and they cannot absorb. much moisture. Hence, even though there be plenty of moisture in the ground the soil may be considered "dry" with reference to plants. They cannot make use of the water which is present in the, soil.

In addition to the inability of roots to absorb moistare there must be considered the high winds which rapidly dry out vegetation and the 
intense light of the noon-day sun which shines through so little atmosphere that it is very bright indeed. As a result of these various unfavorable conditions the mountain tops are able to support only a very sparse growth of plants.

Dryness of soil, intense light, high winds, low temperatures and short summers are all unfavorable to tall growth of plants. But the author

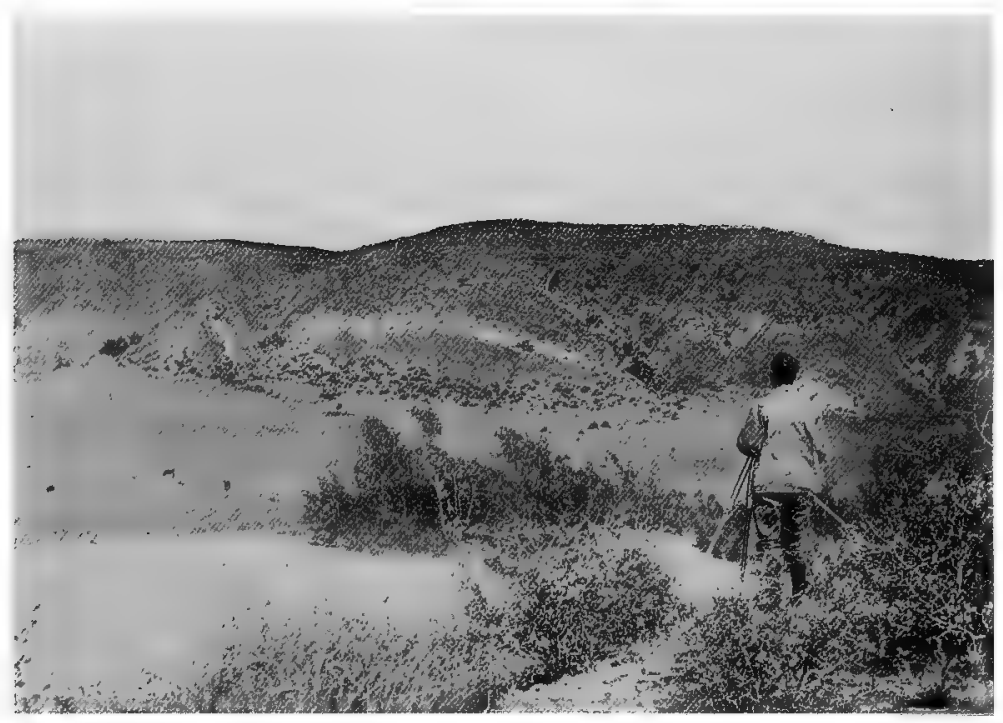

Fig. I4,-A Broad Valley in the Rock Ridge Country

Foldings are seen in the geological strata across the valley. In the foreground are cottonwoods and various deciduous trees and shrubs.

believes that these are not really the cause of the dwarf habit of alpine plants. Alpine plants are plants which have naturally a low, matted form and are therefore able to grow under the severe conditions of the alpine climate. Any other kind would be killed. There are many low, matted plants which grow on the dry plains, too, and on the bare rock ridges of northern Colorado.

It is perfectly natural that there should be a difference in the plants 


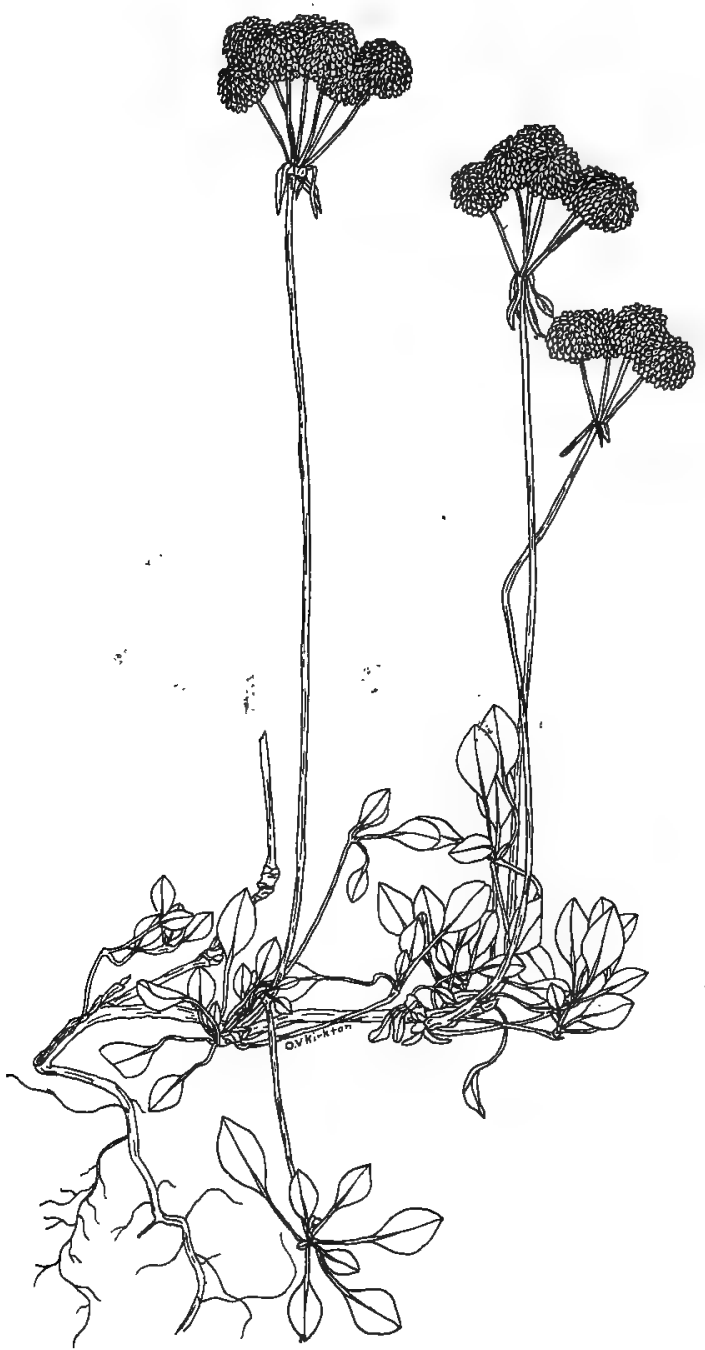

FIG. I5.-SULPHUR FLOWER (Eriogonum umbellatum)

This is a somewhat woolly plant with dense clusters of small sulphur-yellow flowers. The plant here figured belongs chiefly to the foothills, but other species occur at high altitudes, notably one with straw-colored flowers. (One-half natural size.) 
of low and high altitudes. Just as the plants of Louisiana are unlike those of the Hudson's Bay country so we must expect the plants of the plains to be different from those of the high mountains. The climates are as different in the two cases.

If a person sees a sulphur flower on the plains at Denver and then

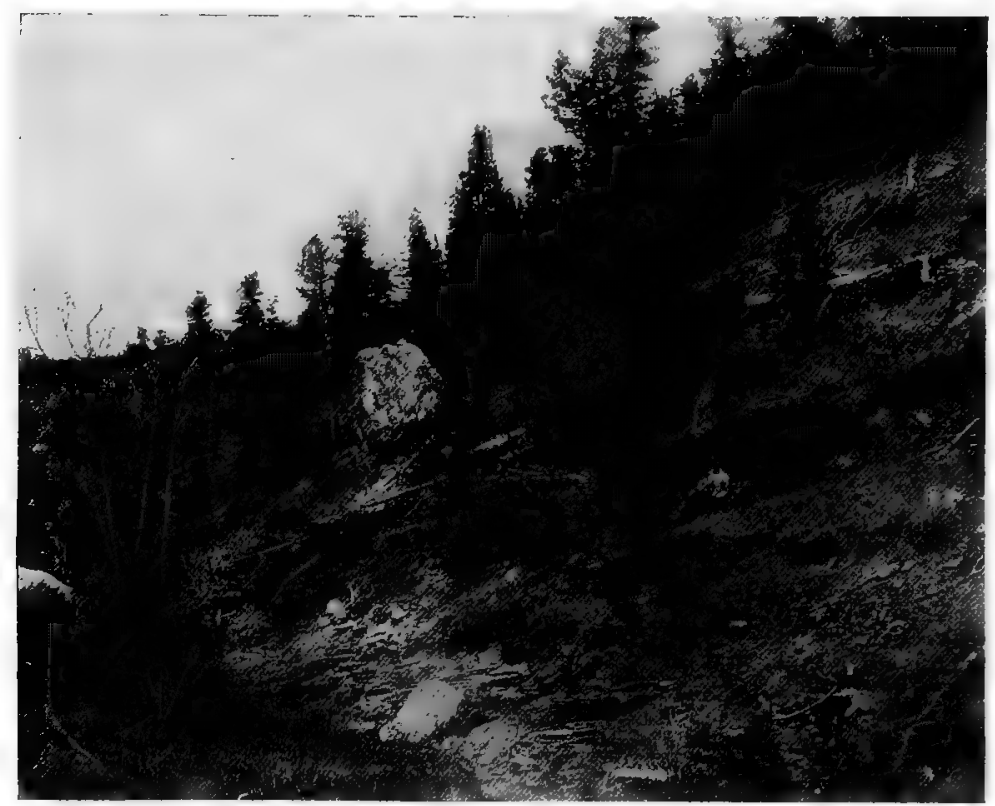

Fig. i6.-Canyon Vegetation

This steep-walled canyon is in the sedimentary rock area of the foothills. At the left are willows and narrowleaf cottonwoods; to the right on the sloping canyon-sides are junipers and cedars. Douglas spruces and rock pines are seen in the background.

sees another plant with somewhat similar flowers on the top of Mt. McClellan he may think that the two are merely forms of the same species altered by the conditions. But this is not the case. They are just as much separate things as are the polar bear and the common brown bears of the temperate zone; just as different as the negro of Africa 
and the white man of Europe. It is not the climate which makes the negro black, the Chinaman yellow and the European white. It is their inner nature. Moved from one continent to another they remain the same color that they were in their former home. So it is, for the most part, with plants.

In most cases when the dwarf, matted species of the alpine heights

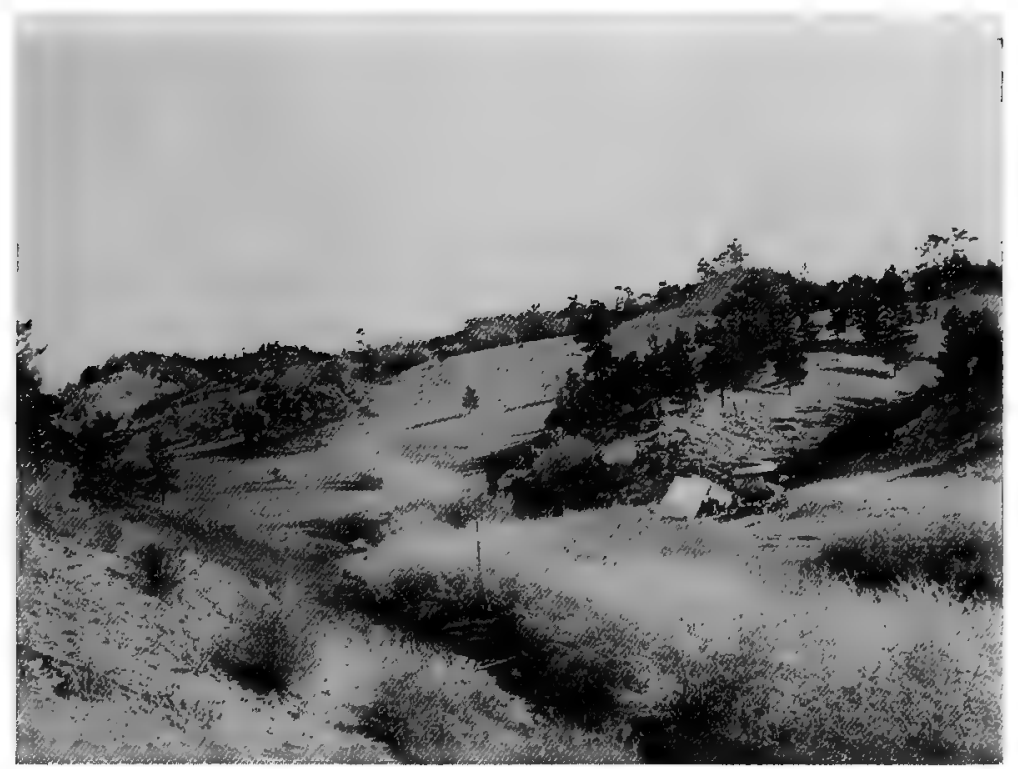

Fig. i7.-Open Foothill Forest

This is a typical scene in the foothill zone; rock pines on the ridges with willows and alders by the stream bank.

are transplanted to low er altitudes and there cultivated they do not change much in form. Many of them refuse to grow in the changed conditions. A few only become modified to any extent.

The principal effect of altitude is to limit the geographical extension of plants by changing the climate. The plants which make their home on the tops of mountains are much like those of the arctic regions. They 


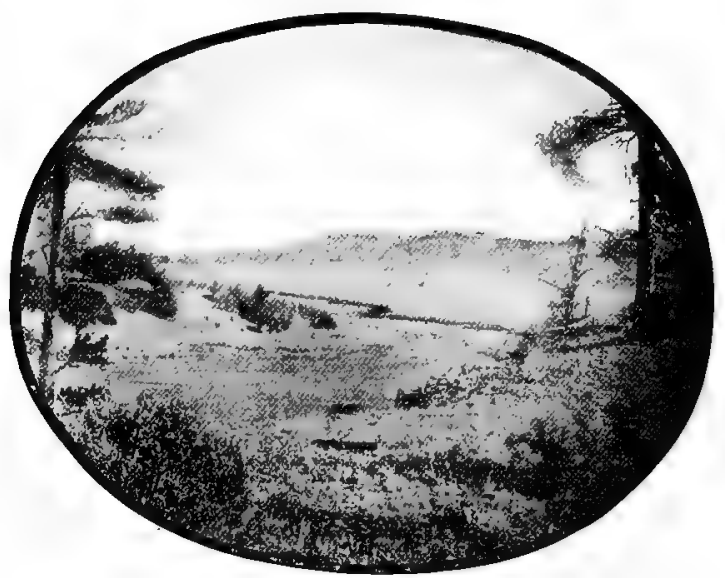

Fig. 18.-Mountain Park in the Foothills

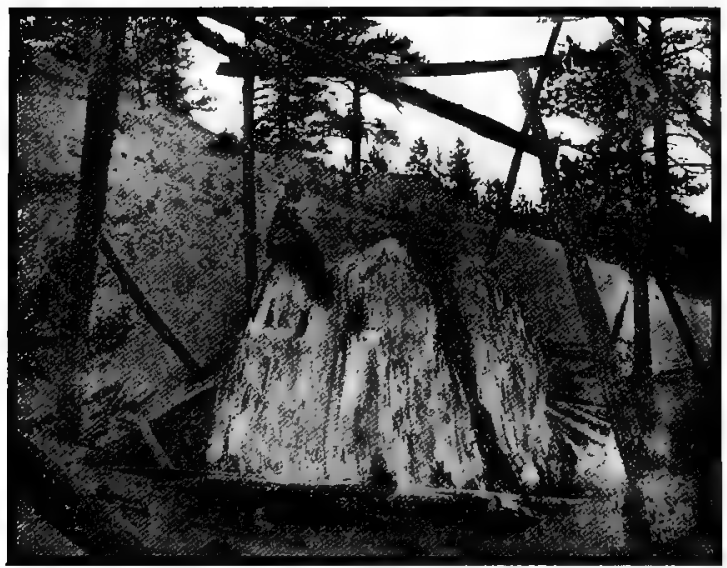

Fig. ig.-Fossil Stump at Florissant, Colo.

This is all that is left of one of the "big trees" which grew in Colorado in former geologic ages. At present the "big trees" grow only in California. 
grow in these places because they, and they alone, are able to withstand the very unfavorable conditions. We must not think that the alpine climate makes the forget-me-not or the mountain campion small. These

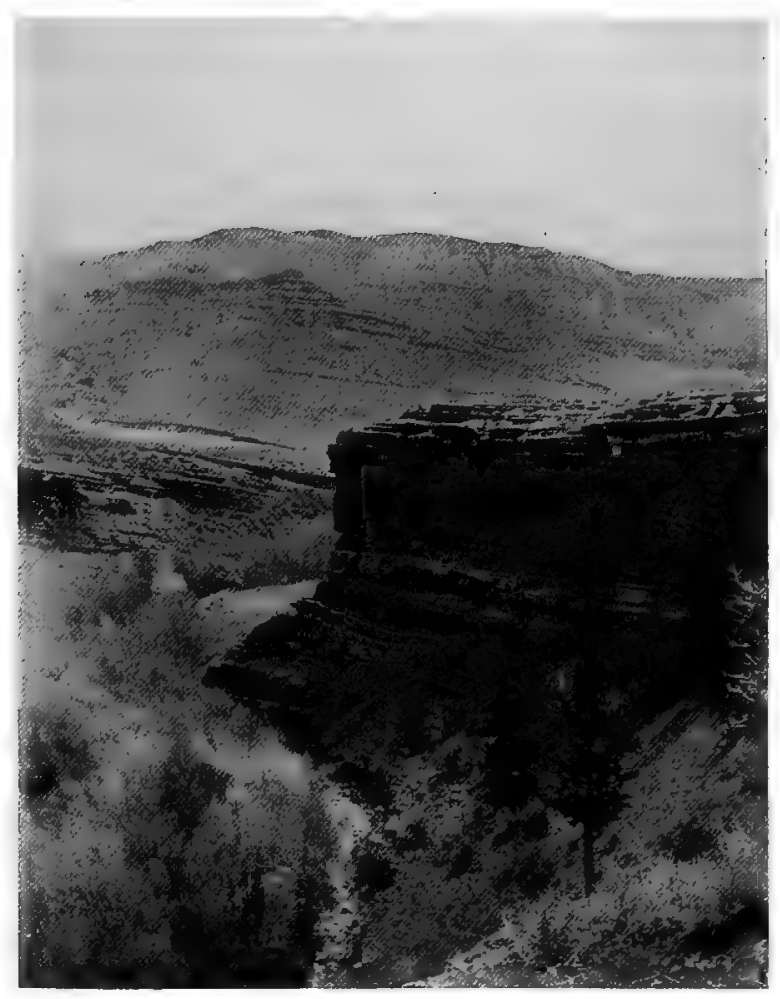

Fig. 20.-Canyon Scene in Northern Colorado

Douglas spruces occupy the shaded slopes while cottonwoods and willows occur in the lower part of the canyon near the water.

plants are naturally small. They are of such a nature that they can get along in dry soil and are not injured by cold. Hence they grow in places where these conditions exist. 
There is no good reason for thinking that plants develop useful permanent structures in response to climate. If useful changes in plant structure become developed by chance variation or otherwise it is likely that the plants thus modified will survive and perpetuate their kind. So, in the course of long ages, plants of a region will appear to have

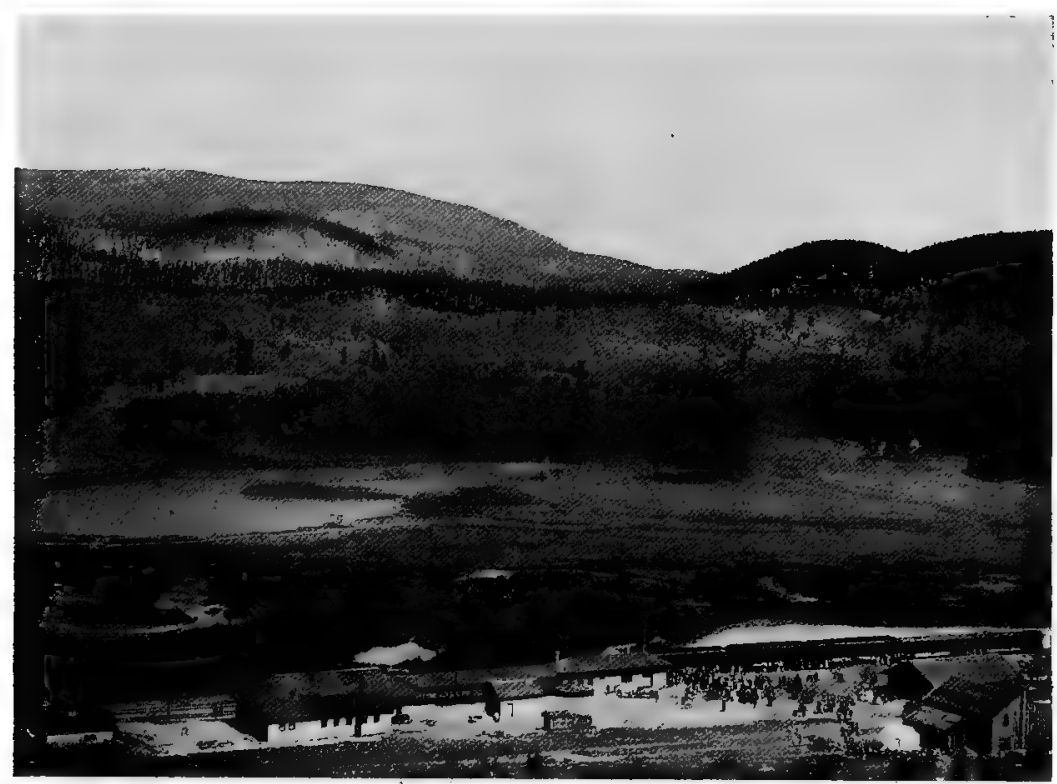

Fig. 2 I.-Park Landscape in the Montane Region

The view is taken at Tolland on the Moffat Road and shows part of South Boulder Park with its winding, willow-fringed creek flanked by meadow land. Park Lake is at the left.

adapted themselves to particular surroundings. Altitude, with its accompanying differences in climate, does not change plants-it merely determines where any particular species will grow.

There are certain other popular misconceptions about plants of Colorado which may be considered briefly. It is a common idea that 

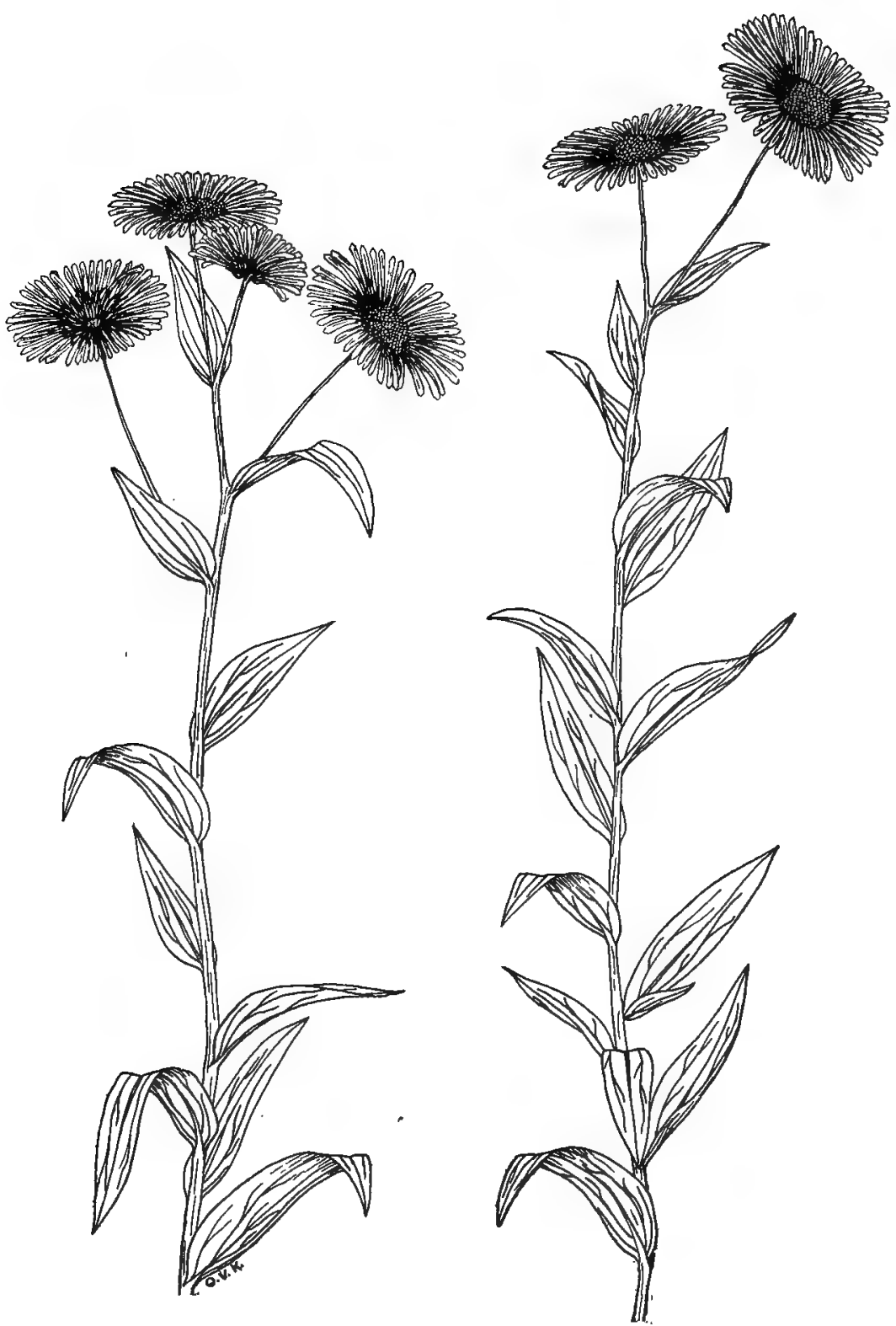

FIG. 22.-MountaIn DaIsy (Erigeron macranthus)

This handsome flower is common in the montane and adjacent zones. Many species of Erigeron are found in Colorado; all look much alike in general appearance but there are differences in the leaves and in the color of the flowers. This particular plant has purplish-pink ray flowers and a yellow center. (One-half natural size.) 


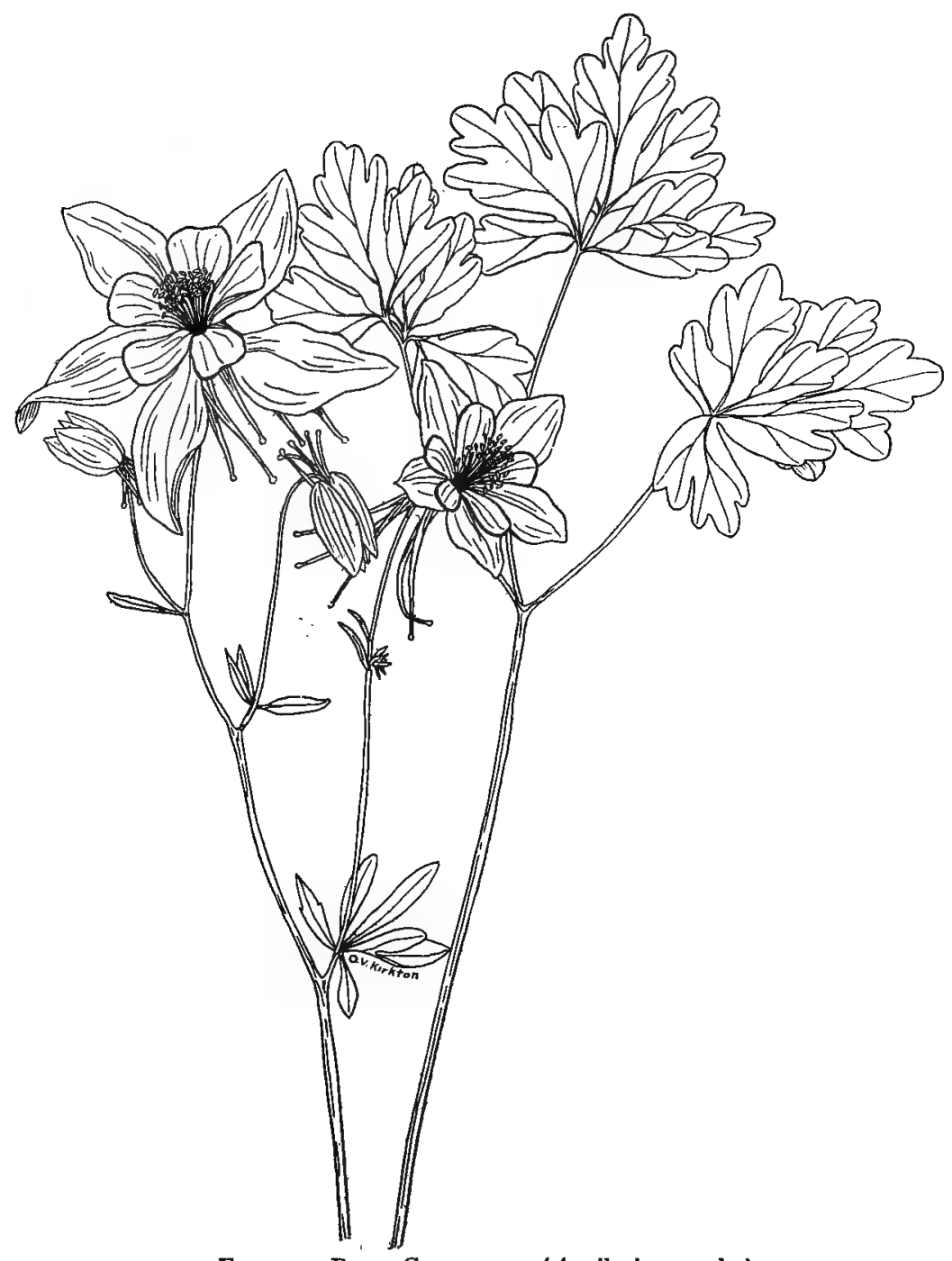

Fig. 23.-Blue Columbine (Aquilegia coerulea)

Everyone knows the Colorado state flower. It grows chiefly in the montane and sub-alpine zones. A yellow columbine occurs in southern Colorado and a red-and-yellow species on the western slope. (One-half natural size.) 


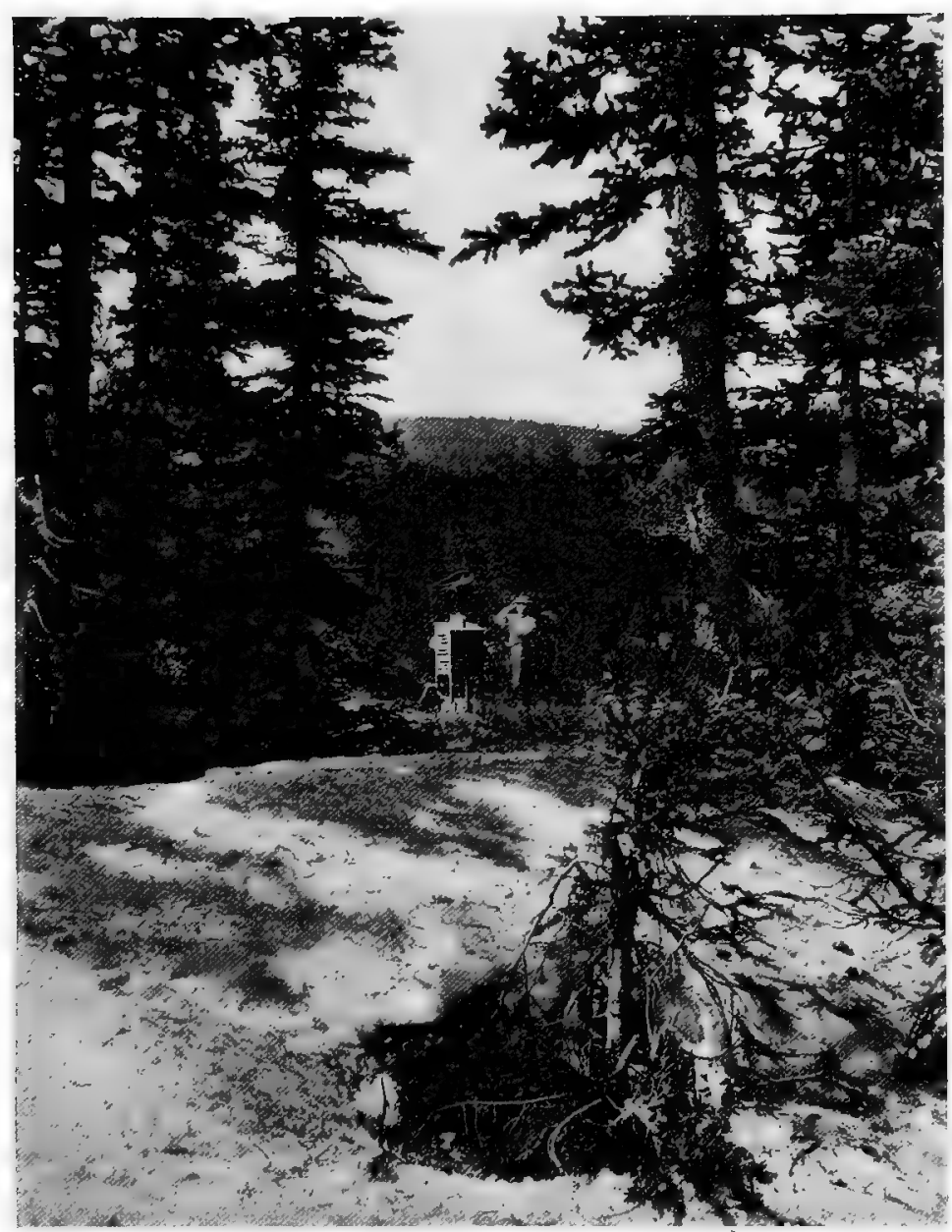

Fig. 24.-A SUB-ALPine Forest

This illustration shows the large size of some of the Engelmann spruces. A snow bank in the foreground is nearly covered up with pine and spruce needles. The small building is a shelter for thermometer and other instruments used by the author in some investigations made in the summer of Igo8. 
because of the altitude or climate there are no bright autumnal colors. There is, however, no foundation for this belief. The poison ivy, the grape, the Virginia creeper are quite as brilliant in the Rocky Mountains as elsewhere. The aspens turn to bright gold in autumn and the hills and canyon sides are aflame with crimson sumacs. It is true that in the cities one may miss the brilliant reds of the hard maple or scarlet oak, for these trees are seldom planted, but there are instead the yellow cottonwoods, locusts and soft maples. Wherever sugar maples and oaks are planted they assume just as beautiful autumn tints as in their native homes.

Another mistaken idea is that Rocky Mountain flowers have no odor. Some flowers here, as elsewhere, are scentless, but certainly not all, nor most all, differ in this respect from plants elsewhere.

The interest which attaches to the wild flowers and trees of Colorado is due to their great variety and to the unusual beauty of many of the individual species. These are not the result of altitude or climate. The great differences in altitude of different parts of the state permit the growth of an unusual number of species and many of these are quite different from those with which the tourist or the settler has been familiar in his eastern home. But plants behave in Colorado much as they do elsewhere in the world. A mountain district is not so different from other regions except in the wonderfully varied conditions which are presented for plant growth.

\section{Plants of the Great Plains}

We sometimes think of the plains as flat expanses, dull and devoid of interest. Yet, for the most part, there is not absolute flatness. Welldrained, gently sloping areas alternate with steep gulches cut by storm waters. There is not, however, that rolling character of the country which belongs to the central and eastern states and which is the result of the action of glaciers of the great ice age. It is easy to see that the great plains represent an entirely different geological formation. Indeed they were sea-bottom in not such very remote geological times and their fine-grained soil is the deposit of silt from ancient rivers. But in the centuries since these deposits were laid down and since the ocean-floor 


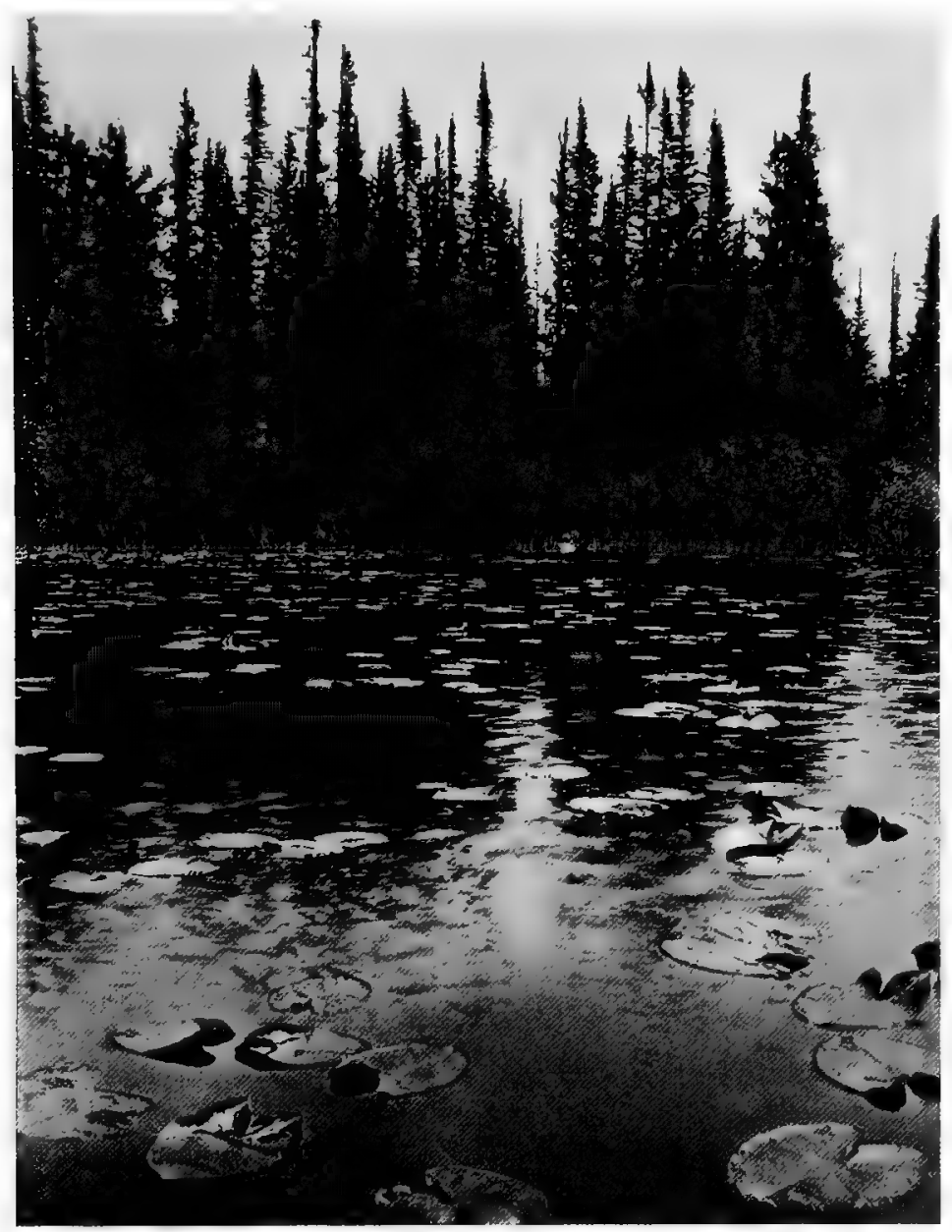

Fig. 25.-SUb-Alpine LaKe Scene

Scattered lily pads are shown floating on the water; sedges occupy the lake edge; these are followed by willows and birches; finally there are the Engelmann spruces of the forest. The pond lilies of Colorado have large yellow flowers. The species is Nymphaea polysepala. 


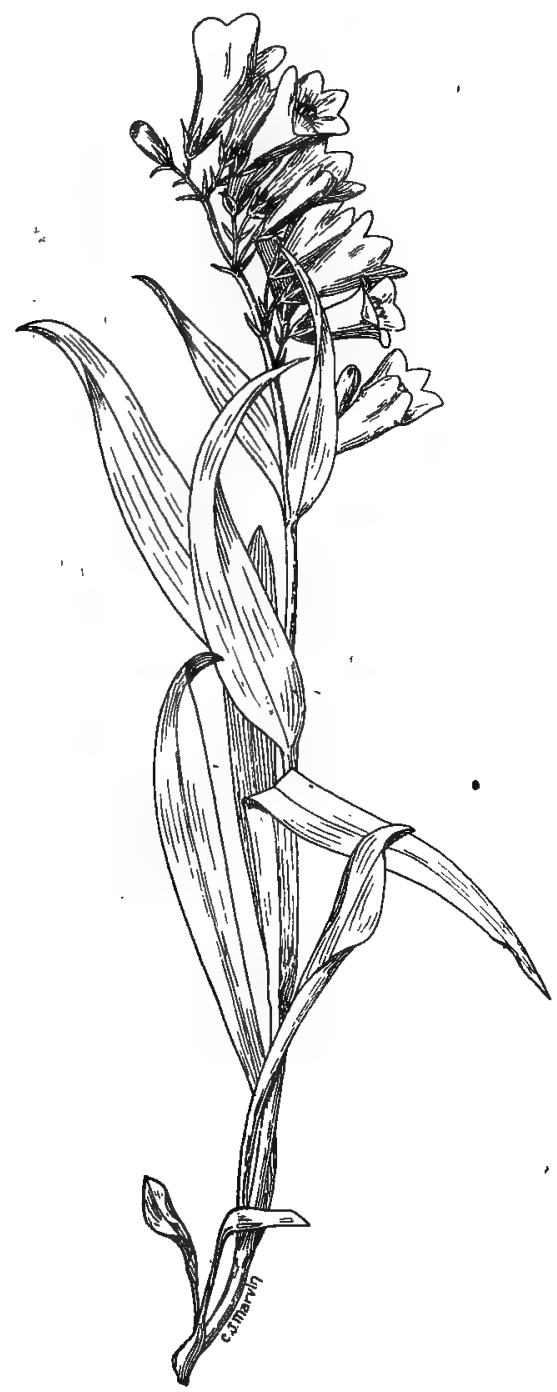

Fig. 26.-BEARd TONGUe (Pentstemon alpinus) -

Colorado is famous for its Pentstemons of which there are fully thirty different kinds in the state. Most of them have blue or lilac flowers although a few are scarlet. The species here figured is very common in late summer in the sub-alpine zone. The flowers are a deep, rich blue. (One-half natural size.) 


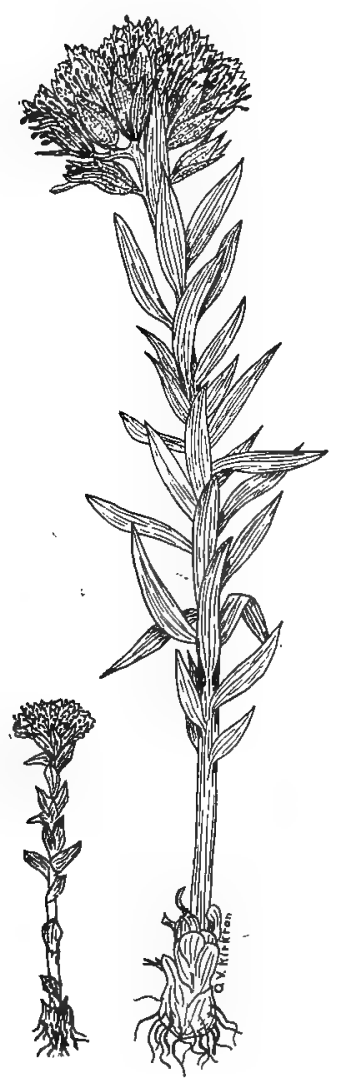

FIG. 27.-RED ORPINe (Clementsia rhodantha)

One of the most interesting sub-alpine plants is here figured. It has fleshy stem and leaves and dark red flowers. The plants grow along streams and in marshy places. When found in dry soil they are small and dwarfed, having the appearance of alpine plants, well shown by the smaller specimen in the drawing. The dwarfing is due to dryness, not to altitude (i. t., cold climate), as is shown by the fact that both the ordinary form and the "alpine form" may occur at the same altitude. The name Clementsia was given to this plant in honor of Professor Frederic E. Clements, a distinguished botanist who has made important studies in Colorado. 
was raised high and dry above the water level, the storm waters from thunder showers and the spring freshets of mountain streams have worn away the land unevenly into valleys, gulches and plateaus.

Even where there has been little cutting away by stream erosion, where the plain is truly a flat expanse, it is interesting and beautiful

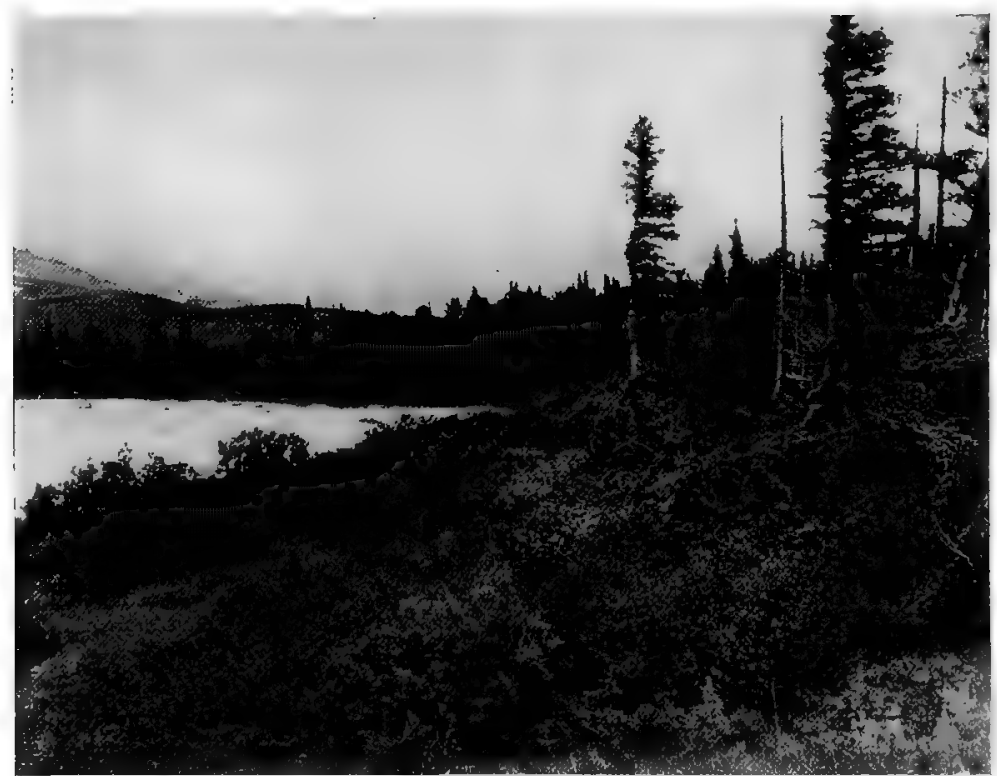

Fig. 28.-Shrubs and Trees near a Sub-alpine Lake

To the left are shrubby willows and birches; at the right are wind-blown Engelmann spruces. It is to be noted that there are no branches on the side of the trees next to the lake. This is due to the prevailing winds which are from that direction.

at least in the joyous spring season. At that time there are days and days with short showers or steady drizzling rain and the dry barren soil becomes moist and fertile. For many of the plains plants the growing season thus ushered in is very short, confined to April, May and June. This is because of the dryness which belongs to summer. So a whole series of profusely-flowering herbs come to blossom in quick succession, 
finish their growth and mature their seeds before the hot, dry months of July and August.

The limits of the present discussion do not permit any detailed account of these plants. Only three examples are chosen for illustration, the sand lily, prickly poppy and evening primrose, while at least fifty hand-

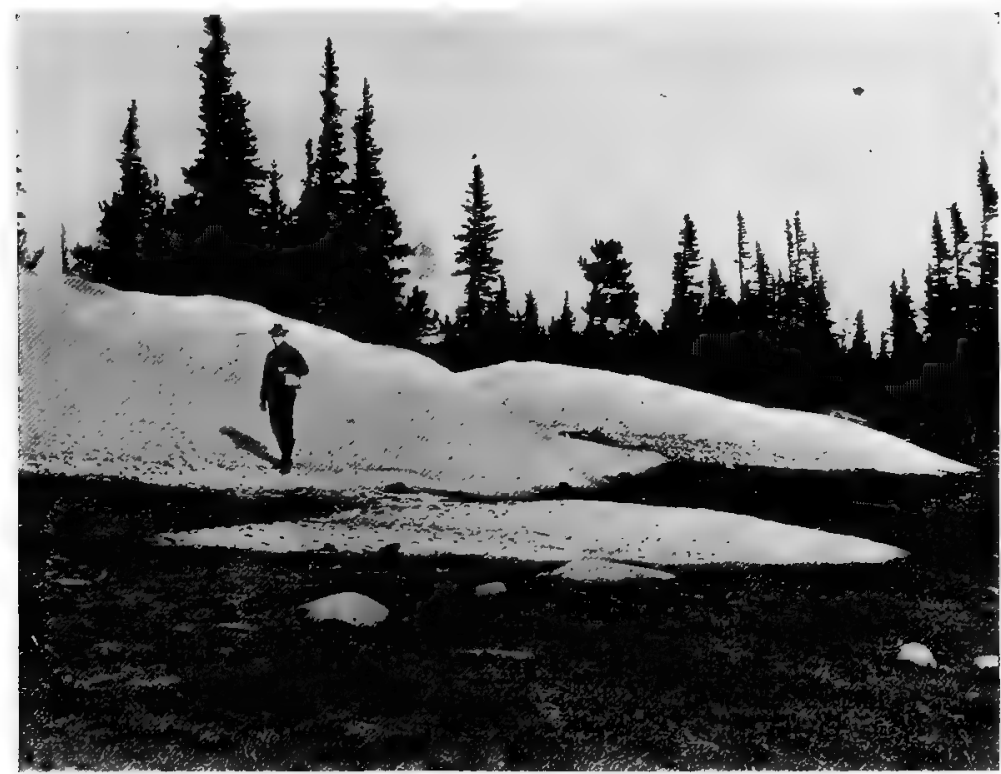

Fig. 29.-SNow Drifts in a Sub-Alpine Forest

These large drifts are located north-east of a ridge which serves as a protection from the heat of the sun. Many large drifts remain in the shelter of ridges or under trees well into June and July.

some and abundant flowers could be named. But it is worth while to call attention to the beauty of springtime on the plains so that those who can may make the most of this beauty. In addition to sand lilies and evening primroses there are milk vetches, multi-colored loco weeds and the brilliant yellow buck beans (Thermopsis). Grotesque prickly pears and other cactuses, so abundant in many places, take on a brighter 
green in early spring and their handsome flowers, some yellow, some red, add much to the beauty of springtime scenes. The Spanish bayonet in blossom is something not soon forgotten, its usefulness for decorative purposes being shown on the title-page of this book.

In speaking of the plants of the plains it will not do to forget the sage brush. What is called sage brush is very different from what house-

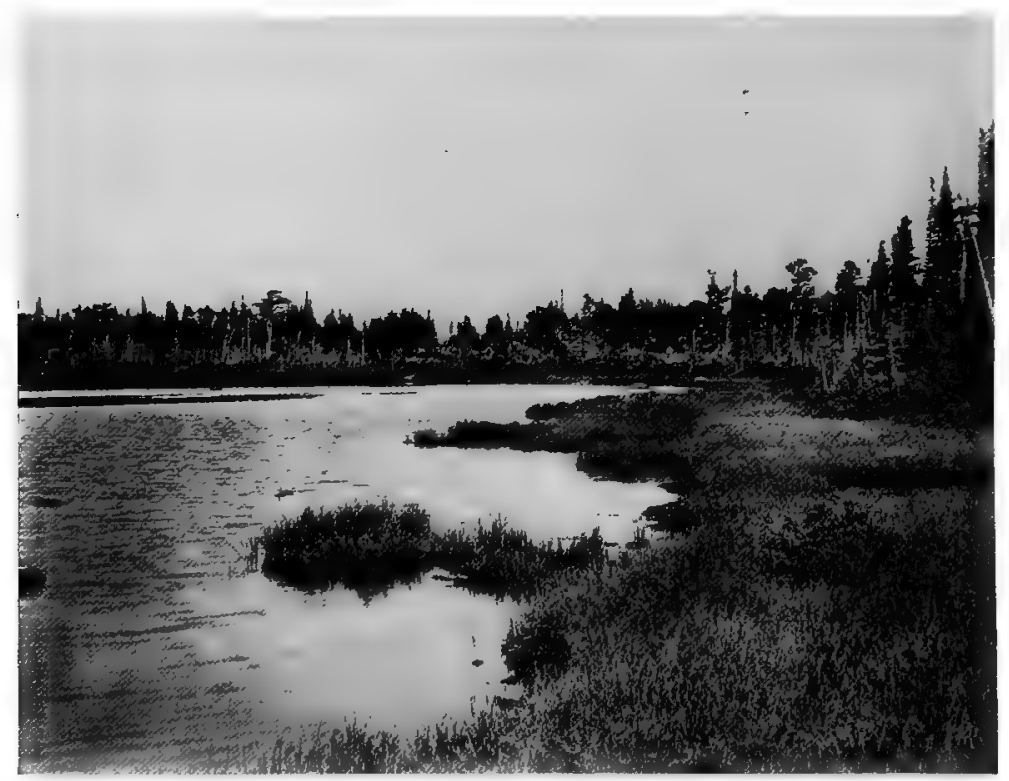

Fig. 30.-Sub-alpine Lake Shore

The sedges and grasses in their growth encroach upon the water and will eventually fill up the lake converting it into a meadow.

wives use to flavor their Thanksgiving turkey. There is a little of the same odor but at this point the resemblance stops. Many of the plants are not large, being only a few inches high. Others have a distinctly bushy form and grow about three or four feet tall. The whitish green of the leaves and stems gives impress to the landscape. Some prosaic people do not like it. They say that it gives an air of barrenness to the 


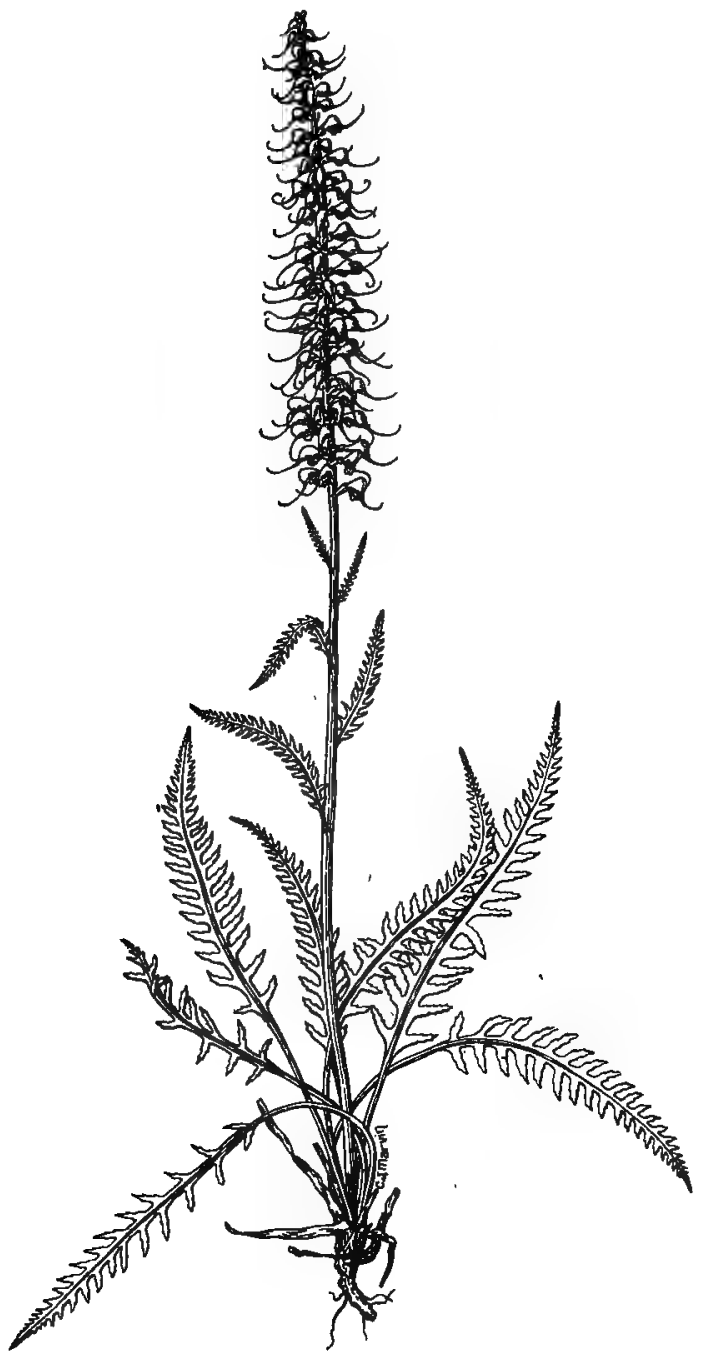

Fig. 31.-Little Red Elephant (Elephantella groenlandica)

A common plant of sub-alpine bogs or marshy ground along streams and around lakes. The flowers are dark red or crimson. (Two-thirds natural size.) 


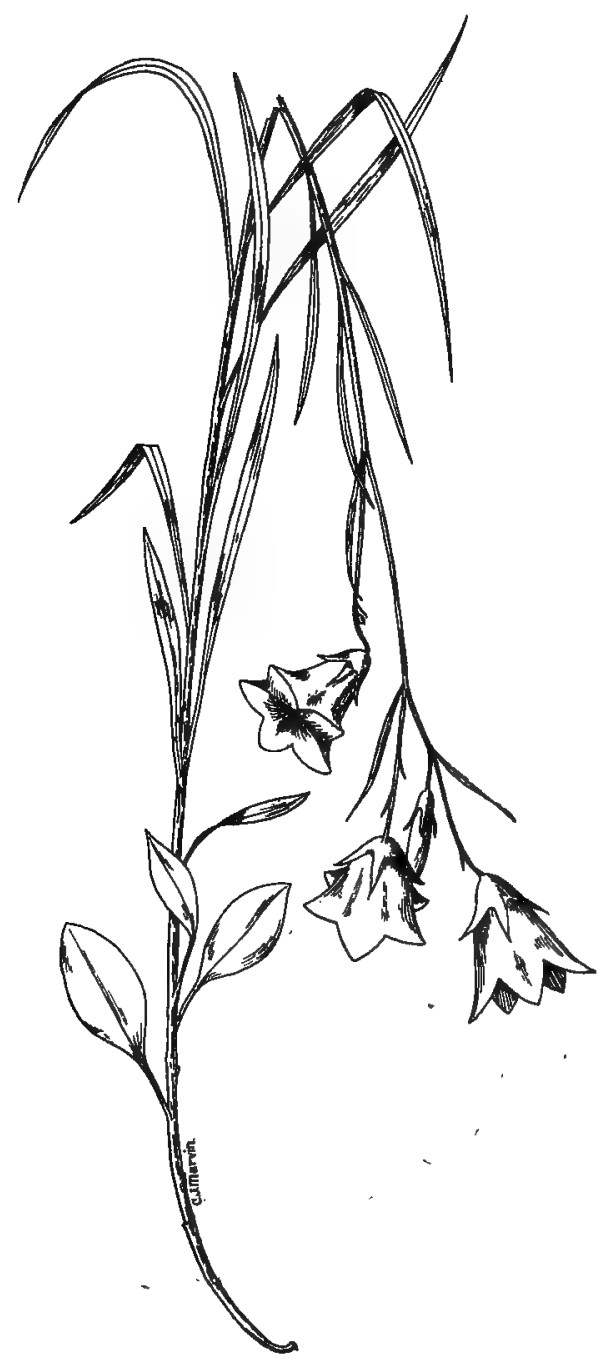

Fig. 32.-Harebell (Campanula petiolata)

This handsome blue-flowered plant is common in the moist parts of the alpine zone in late summer. It also grows in the other life zones down to the foothills. (Two-thirds natural size.) 
view; but, even so, the nature-lover enjoys it. Something of the artistic temper seems needed for an appreciation of the beauty of this soft green. There is none of the vividness which means fulness of life-that is seen in the grasses of early spring-but there is a charm in the delicate-colored landscape of midsummer with its dull brown of dead grass stems and the soft gray of sage brush.

\section{Mountain Parks}

It is quite out of the question to close this very short account of Colorado wild flowers without some mention of mountain parks. The author has in mind Estes Park, South Boulder Park and some of the valleys in Platte Canyon. A mountain park may be defined as a level area in the foothill or montane district surrounded by hills and mountains. Some of the parks are a few acres in extent, some are many square miles. Botanically they may be considered as enclosed prairies shut off from other prairies by high hills and communicating with the lowlands by means of a river gorge through which flows a mountain stream. Along the course of the stream there is usually a broad area with rich soil and plenty of seepage water where luxuriant vegetation develops.

Colorado belongs to the "great dry country" and there are few places in the state which offer views of green meadows and winding streams. But the meadows of the mountain parks are most beautifully green. Even to late summer and autumn the color continues and there is a sharp contrast with the dull gray and brown of hillsides or the whiteness of distant snowfields on the alpine peaks.

When we climb out of the park up the side of one of the surrounding foothills and look below us we see broad level sunlit reaches, shallow valleys and rolling hills. Beyond all this, across the park, are the foothills which shut it in on the other side. The creek may be seen as a silvery thread which winds along toward the canyon which is the outlet to the park.

There can be no adequate written description of a mountain park. When the topography is described and when all the trees and grasses and flowering herbs are named there are still the delicious mountain air and the pure sunlight. These are forever unknown to one who lives 


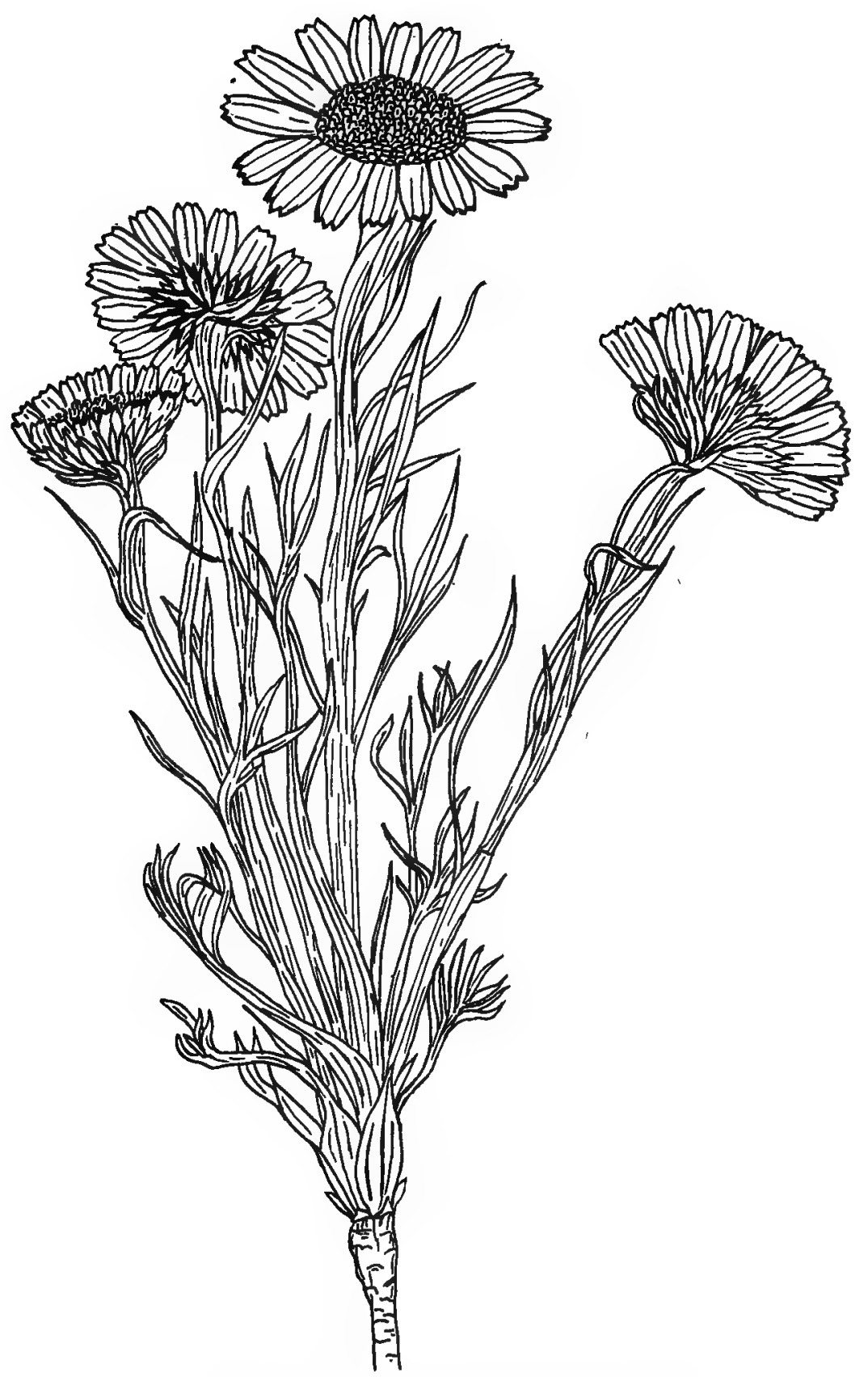

Fig. 33.-Rydbergia (Rydbergia grandiflora)

This beautiful plant is named in honor of Dr. Per Axel Rydberg, the distinguished author of the Flora of Colorado. It is one of the most striking plants of the alpine zone, being common in moister places in early summer. The ray flowers are a handsome yellow and the center orange-brown. (Two-thirds natural size.) 


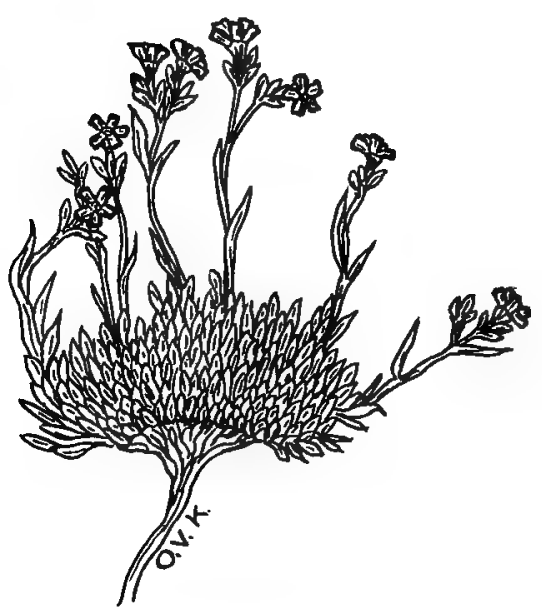

FIG. 34--FORGET-ME-NOT (Eritrichium argentium)

A small, low, matted plant able to endure the extreme cold of the alpine climate. The flowers are a pure blue. (Natural size.)

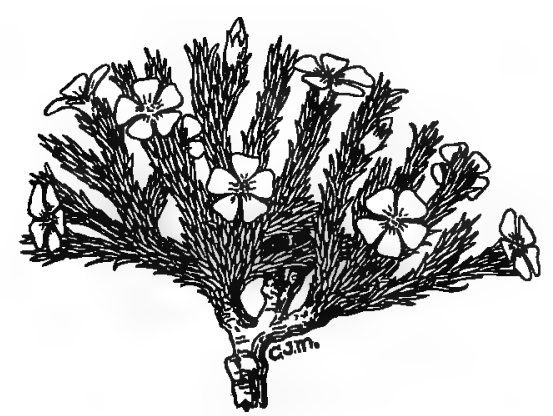

Fig. 35.-Mountain Campion (Silene acaulis)

A typical matted plant of drier places in the alpine zone. It is well adapted to the severe climate. 
his life east of the great plains. Day after day the sun comes up unclouded over the eastern hills and shines resplendent from the great blue sky. Without moisture or dust in the air the blueness is intense. The trees cast black shadows on the ground beneath. There is no blending of colors in the landscape. Everything stands out boldly. No haze obstructs the view. In the afternoon a shower comes up with thick black clouds rolling into ominous mountain masses-a few drops of rain, perhaps distant thunder, and again the bright azure sky.

So the charm of the mountain park to the nature-lover comes not only in the gullies and ridges, in the wild flowers and trees, but also in the light and shadow, which, ever changing, fill the landscape with interest. The matter-of-fact man may say that a pine tree is just a pine tree; but he who studies just one single pine tree knows that it is not always the same. With the times of day the shadows change and each separate hour gives new objective sensations which change our inner feelings of the world about us. The charm of the mountain park is in the green waving meadows, pine barrens and quaking aspens, loco and sage brush - and everything more beautiful and full of interest because of the tonic air and brilliant sunshine. 


\section{FOREST FORMATIONS AND FOREST TREES}

The study of trees.-Anyone who wishes some acquaintance with plants may well begin with a study of trees. For such study only a very little technical knowledge is required, while to learn much about "wild flowers" or grasses or ferns it is necessary to master a great many special terms. The trees in Colorado are so few that it is possible in a single season to become well acquainted with most of the different kinds in any particular locality. Hence the student who is looking for rapid results may well begin any outdoor botanical work with a study of trees.

Scientific names.-Every plant known to science, whether a tree, shrub or herb, has what is known as a scientific name. Thus Populus $a l b a$ is the white poplar, Populus nigra the black poplar, etc. In each case Populus is the generic name. The particular kind of poplar is indicated by the specific name. So all oaks are known as Quercus, all elms as Ulmus, etc. As a rule botanists agree on these scientific names which are the same in all countries. of the world, but in some cases there is a difference of opinion. This is well illustrated in the case of the maples and box-elders. Acer, the ancient name for maple, is used for all of the true maples but it is a question among botanists whether or not the boxelder should be called Acer. Indeed, many people, disregarding the similarity of fruits and seeds, say that box-elder is something entirely apart and should have a different name. For this purpose the names Negundo and Rulac have been employed. Another source of confusion comes through the naming of the same species by two or more different botanists working separately and not knowing of the work of the others. A particular kind of tree or other plant may thus receive two or more names and each of these names may come into use among certain people. It is a rule that the oldest published name is to be followed if the plant has been named in the correct genus. So it often happens that a much-used name has to be discarded when the true history of the plant becomes fully known. In technical descriptions 
the name of the botanist who has described the plant is affixed to the scientific name. This is done in order that anyone wishing to examine the original description of the plant may more easily find it.

Forest formations. - It is a simple matter to classify the forests of Colorado. They fall into two groups, those of the plains region and those of the mountain districts. The former are of slight economic importance at the present time but their existence suggests the possibility of tree-planting which may in time become highly profitable. River-bottom forests and pine-ridge forests occur in the plains region to the east of the continental divide, while in the western part of the state there are large areas with a growth of quaking aspen and of pinyon pine which it is difficult to classify. They might be termed either pineridge or foothill forests. In the mountain districts there are no trees of importance except the "evergreens."

Forest formations of mountain districts.-These are composed of coniferous trees, the various species of pine, spruce and fir and the single species of Douglas spruce. Generally the foothills support an open formation of rock pine ${ }^{\mathrm{x}}$ while in the moister canyons there are Douglas spruces. ${ }^{2}$ In southern Colorado the pinyon pine $^{3}$ forms a conspicuous part of the foothill forest and in places in the southern and western parts of the state there are some oaks of consequence. In the montane region a closer forest exists, composed largely of lodgepole pine, ${ }^{4}$ with some Colorado blue spruces 5 along the streams. The best timber, however, is in the sub-alpine spruce forests. These consist essentially of Engelmann spruce ${ }^{6}$ with some admixture of limber pine, ${ }^{7}$ sub-alpine and white fir $^{8}$ and, in places, bristle-cone pine. ${ }^{9}$

Forest formations of the plains region.-The river-bottom and pine-ridge forests occupy essentially different habitats. Along the water courses there is found a good growth of cottonwoods and willows with occasional box-elders, hackberries, mountain maples and alders. Where the stream has not cut a deep bed, and the ground slopes gently

1 Pinus scopulorum.

- Pseudotsuga mucronata.

3 Pinus edulis.

4 Pinus murrayana.

sicea parrayana.

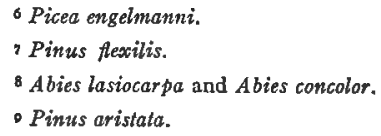


away at the sides, these river-bottom forests may be a quarter or halfmile in width. More often, however, they are much narrower. Along the smaller streams there is frequently a single row of cottonwoods or willows. The pine-ridge forests are on the high ground extending between adjacent streams where they grow in coarse, frequently rocky soil. Good examples of pine-ridge forests are seen along the divide between the South Platte and the Arkansas and also at the edge of the

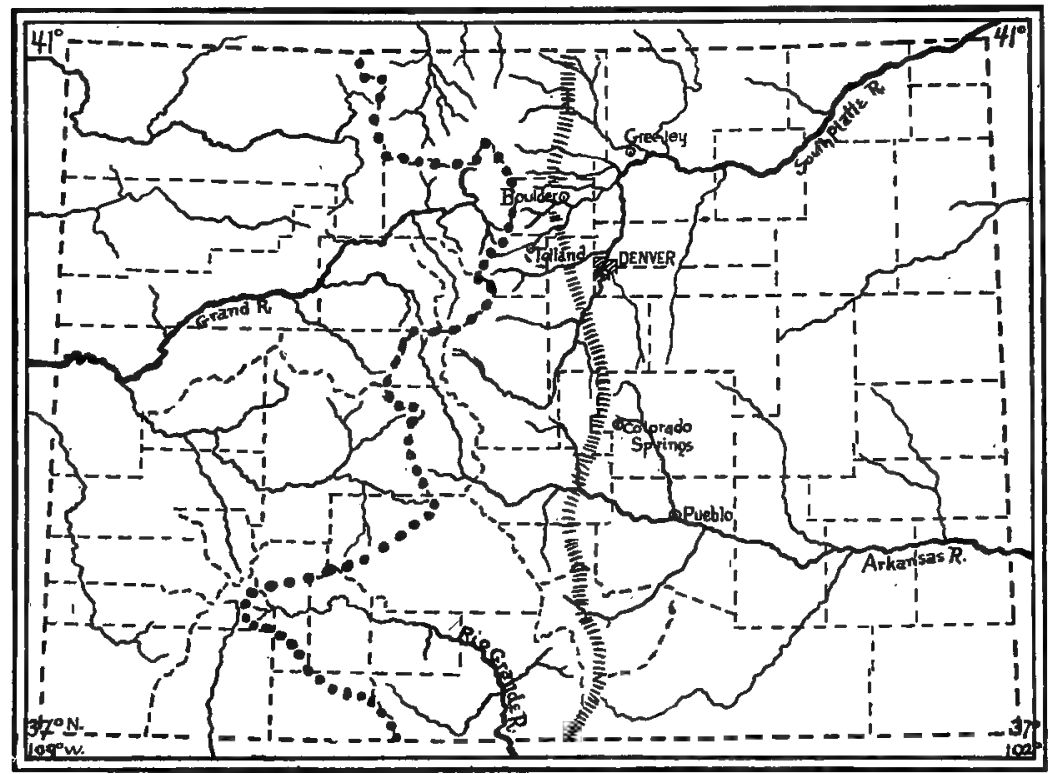

Fig. 36.-Map of Colorado. The continental divide is shown by the heavy dotted line, the front range of foothills by the short horizontal lines. East of the foothills lie the great plains.

"high plains" in the northeastern part of the state. The trees of these ridges are rock pines and cedars which form scattered groups hardly to be dignified by the name of forest. Near Pawnee Buttes in northeastern Colorado there are limber pines instead of rock pines. To the south, and in certain parts of the western area of the state, the pinyon pine is added to the rock pine and cedar.

Classification of forests.-From a botanical standpoint forests may 
be distinguished as mesophytic and xerophytic. The former are those made up of trees requiring a moderate amount of moisture, the latter are dry-country forests capable of enduring drought; they occur in regions of slight rainfall or in situations where the run-off is rapid. Mesophytic trees in Colorado are confined to areas where there is considerable seepage water, except in the case of Engelmann spruces in the sub-alpine zone where there is much more rainfall than at lower altitudes.

It may be convenient to list the principal forest formations of Colorado in tabular form.

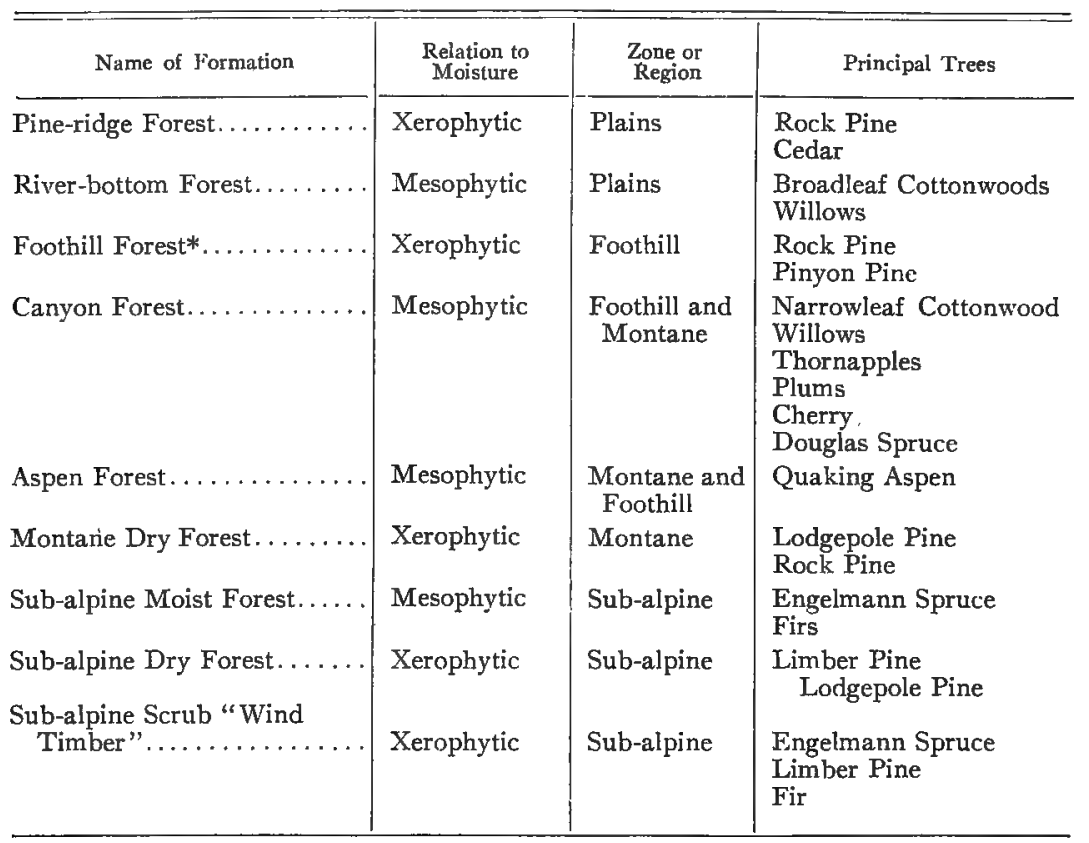

* The pinyon pine is found only in the warmer and drier parts of the state. Oaks, chiefly shrubby species, enter into the foothill forest formation in certain places. They are entirely absent from the foothills north of Denver.

Distribution of species. - The tree flora of the state embraces fiftyfive species belonging to twenty genera. Most of the individuals, as well as the species in general, are found in the foothill, montane and sub-alpine zones of plant life. Timberline, at about 11,000 or 12,000 
feet above the sea, is the upper limit of tree growth, although some shrubby willows occur in the alpine zone above. As noted in the preceding pages; the trees of the plains are to be found only along water courses or on the pine ridges of the high divides between streams. In the following table the general distribution of each tree is stated in relation to the continental divide, which extends north and south through the

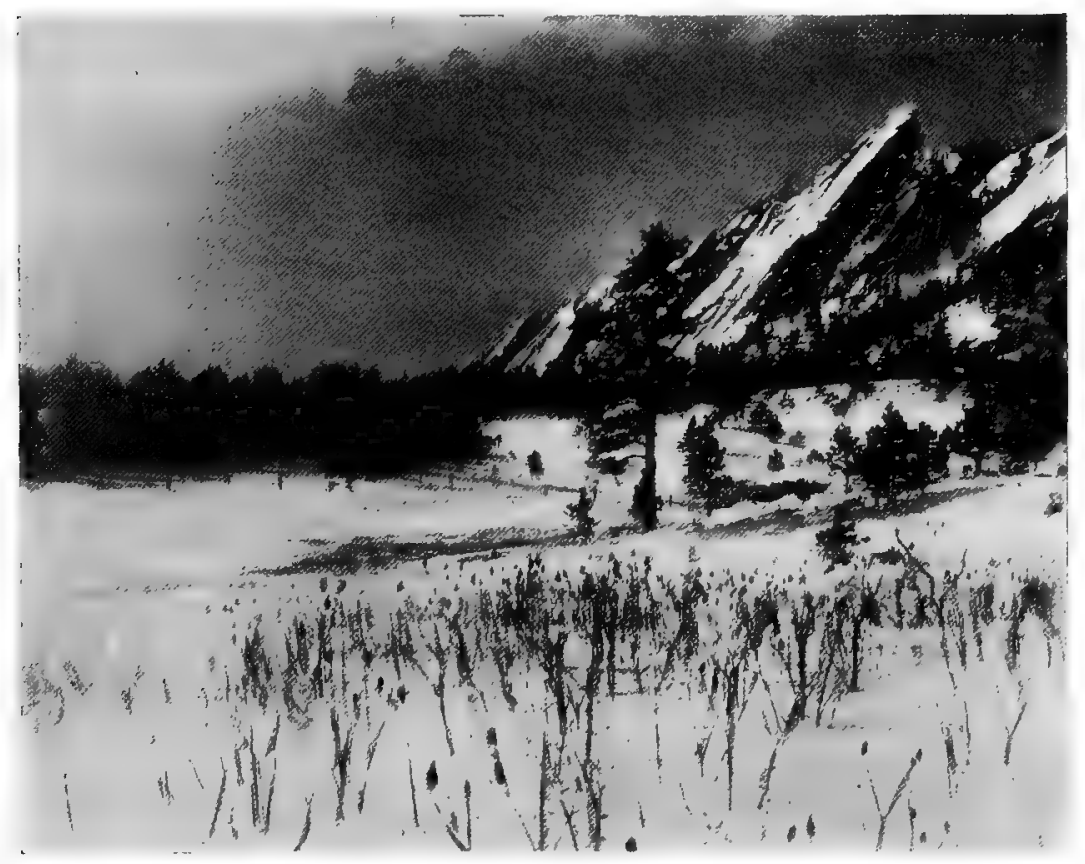

Fig. 37.--Rock Pines

Lower limit of tree growth on mesas and foothills. Young sumacs in the fore. ground. Late winter.

state, dividing it into nearly equal parts. It will be noticed that nearly all of the trees occur both east and west of the divide, somewhere in their distribution. As a matter of fact the same species does not necessarily occur at opposite points east and west of the main range. Those oaks, for example, which are present in the northwestern part of the state do not cross to the foothills of the eastern slope in northern Colorado but 
are found at Colorado Springs and southward. The distribution of the pinyon pine is similar. Many of the high-altitude trees extend far north to British Columbia and even Alaska. A considerable number range to the Pacific coast, but only a few show a distribution far eastward.

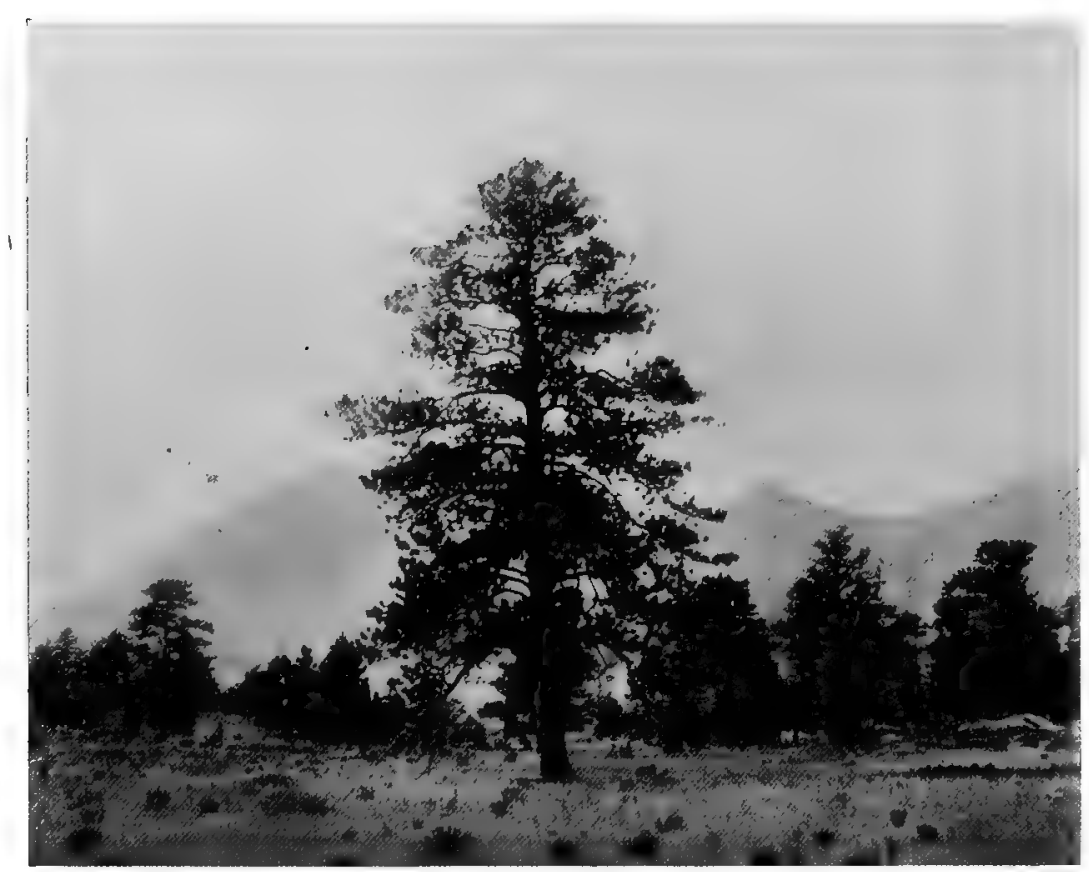

Fig. 38.-Rock Pine, Growing in the Open, Estes Park

Limits of tree distribution. - The upper limit of tree growth, or timberline, is variable as to altitude. On north exposures the trees do not extend so high up the mountain side as they do on the warmer and less windy south slope. Cold, wind and dryness all combine to limit the upward extension of forests on mountains. At timberline are found scattered clumps of wind-blown trees often contorted into fantastic 
shapes. ${ }^{\mathrm{I}}$ At the lower limit of forest growth, on the foothills and mesas adjoining the plains, the trees are unable to extend out to the plains largely because of the fine soil which supports a thick covering of grasses and does not permit trees to become started. Differences in climate are also important. The plains have colder winters and warmer summers, than the adjacent foothills. ${ }^{2}$ In the mountain parks, which are

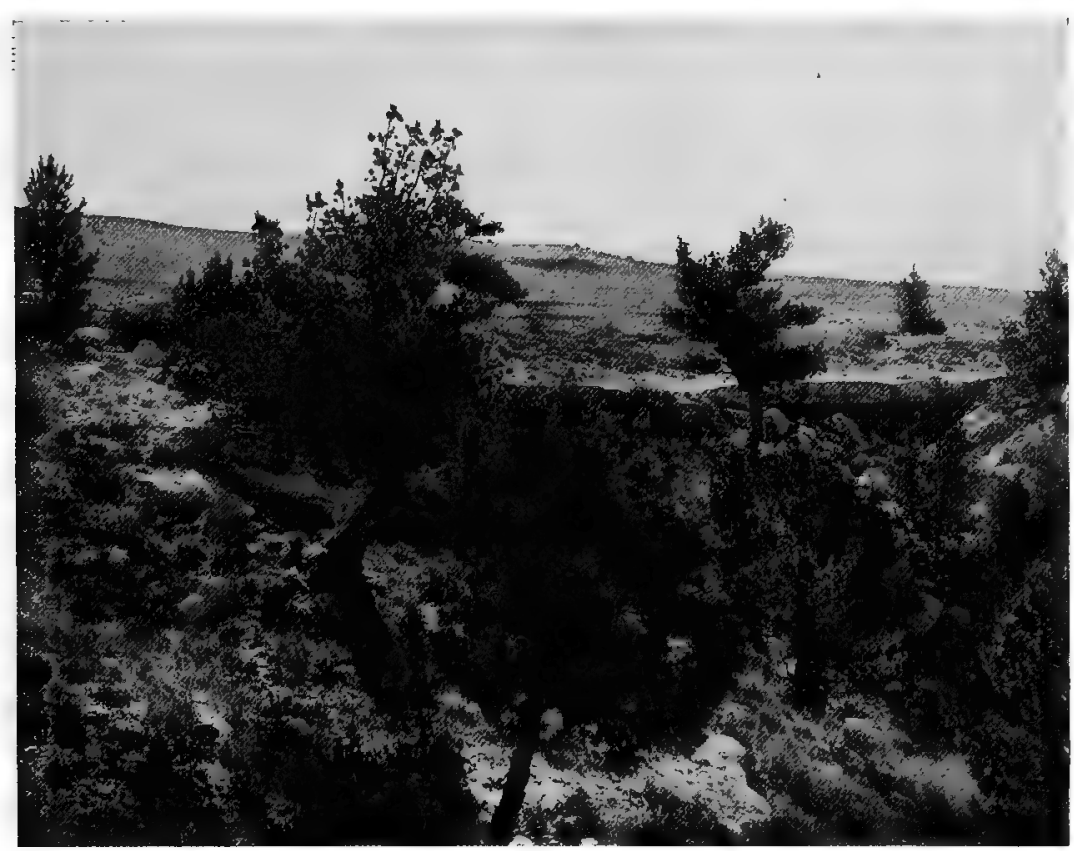

Fig. 39.-Limber Pine near Pawnee Buttes, Colo.

This is the most eastward extension of its range.

certain broad valleys of the foothill and montane regions, while forests are present on the hillsides there are only a few scattered trees on the level ground below. This absence of trees is probably to be accounted for by the fineness of soil and greater severity of climate.

× This subject is discussed with some completeness by Mr. W. S. Cooper in an article referred to in the bibliography. From II,000 to $1<, 0>0$ feet may be considered the usual limit of trees.

a A comparison of the climates of plains and foothills is made by the present writer in the article referred to in the bibliography: "Studies in Mesa and Foothill Vegetation." 


\begin{tabular}{|c|c|c|}
\hline Name of Tree & $\begin{array}{l}\text { Relation to Con- } \\
\text { tinental Divide }\end{array}$ & Zone or Region of Occurrence \\
\hline Pinus aristata & Fast and West & Montane, Sub-alpine \\
\hline edulis. & East and West. & Foothill \\
\hline flexilis. & East and West & Sub-alpine, Montane (Foothill) \\
\hline murrayana. & Fast and West & Montane, Sub-alpine (Foothill) \\
\hline scopulorum. & East and West & Foothill, Montane \\
\hline Picea engelmanni........... & East and West & Sub-alpine, Montane \\
\hline parryana............... & East and West & Montane, Foothill \\
\hline Pseudotsuga mucronata..... & East and West & Foothill, Montane \\
\hline Abies concolor........... & East and West & Montane, Foothill \\
\hline lasioearpa.......... & East and West & Sub-alpine, Montane (Foothill) \\
\hline Sabina monosperma. & East and West & Foothill (Plains) \\
\hline $\begin{array}{l}\text { scopulorum. } \\
\text { utahensis... }\end{array}$ & East and West & Foothill, Montane, Plains \\
\hline $\begin{array}{l}\text { utahensis... . } \\
\text { Populus acuminata. }\end{array}$ & & Foothill, Plains \\
\hline angustifolia. . & $\begin{array}{l}\text { Last and West (?) } \\
\text { East and West }\end{array}$ & $\begin{array}{l}\text { Foothill, Plans } \\
\text { Foothill, Montane, Plains }\end{array}$ \\
\hline balsamifera. & East and West & Montane, Foothill \\
\hline sargentii.... & East & Plains, Foothill \\
\hline tremuloides. & East and West & Montane, Foothill, Sub-alpine \\
\hline wislizeni..... & East and West (?) & Plains, Foothill \\
\hline Salix amygdaloides. & East and West & Plains, Foothill (Montane) \\
\hline bebbiana... & East and West & Foothill, Montane, Plains \\
\hline exigua & East and West & Plains, Foothill (Montane) \\
\hline lasiandra & East and West & Foothill, Plains (Montane) \\
\hline nuttallii.. & East and West & Foothill, Montane \\
\hline sessilifolia. & East and West & Foothill, Plains \\
\hline Betula andrewsii.. & East & Foothill (Montane) \\
\hline fontinalis & East and West & Foothill, Montane \\
\hline Alnus tenuifolia. & East and West & Foothill, Montane (Plains) \\
\hline Quercus gambellii & East and West & Foothill \\
\hline leptophylla. & East and West & Foothill \\
\hline nitescens. & East and West & Foothill \\
\hline utahensis. & East and West & Foothill \\
\hline Celtis douglasii. & East (?) West & Foothill \\
\hline -1 reticulata. & East and West & Foothill, Plains \\
\hline Cercocarpus ledifolius. & West & Foothill, Plains, Montane \\
\hline Amelanchier alnifolia. & East and West & Plains, Foothill, Montane \\
\hline Crataegus cerronis & East and West & Foothill \\
\hline coloradensis & East & Foothill \\
\hline coloradoides & East & Foothill \\
\hline doddsii & East & Foothill \\
\hline laurentian & East & Foothill \\
\hline occidentalis & East & Foothill \\
\hline rivularis.. & West & Foothill \\
\hline saligna & West & Foothill \\
\hline Prunus americana. & East & Foothill, Plains \\
\hline melanocarpa. & East and West & Foothill, Plains, Montane \\
\hline & East & Foothill, Montane, Plains \\
\hline Robinia neomexicana & East and West (?) & Foothill, Plains \\
\hline Acer glabrum... & East and West & Foothill, Plains, Montane \\
\hline grandidentu & East and West & Foothill, Montane \\
\hline interior. & East and West (?) & Plains, Foothill \\
\hline Rhus glabra. & East and West & Foothill, Plains \\
\hline Rhamnus purshian & West & Foothill \\
\hline Fraxinus anomala. & West & Foothill, Plains \\
\hline
\end{tabular}


Colorado forests in former geologic times.-Professor T. D. A. Cockerell, the authority on fossil plants of the Rocky Mountains, has recorded a large number of species of trees which formerly grew at Florissant and at other places in Colorado. The most easily accessible of his papers are referred to in a footnote. ${ }^{\mathrm{I}}$ It appears that the forests of Miocene times were made up of pines, cedars, willows, cottonwoods,

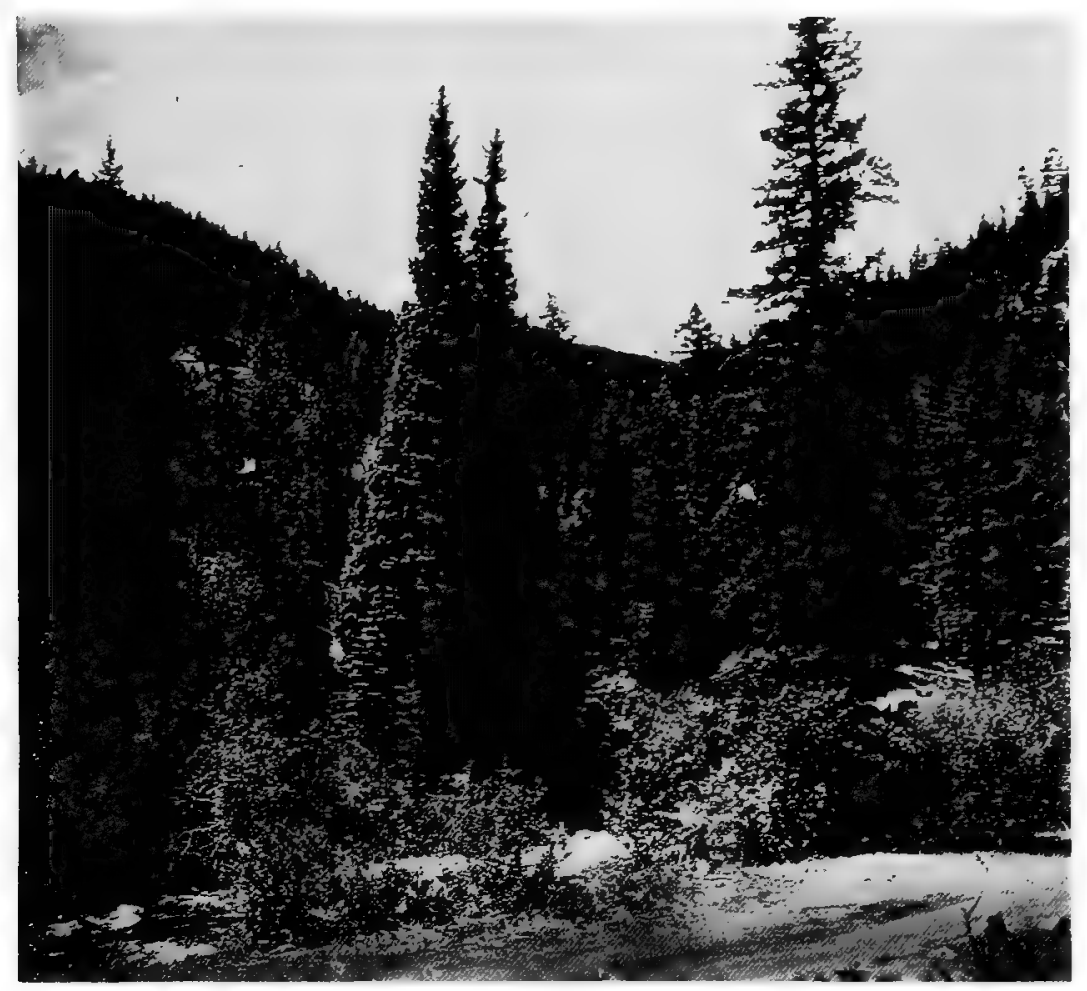

Fig. 40.-Colorado Blue Spruce

birches, alders, oaks, hackberries, June berries, thornapples, locusts, sumacs, maples, buckthorns and ashes, besides a number of eastern

' Cockereli, T. D. A., "Florissant; A Miocene Pompeii," Popular Science Monthly, Vol. LXXIV, pp. 1 12-126, 1908. " "Some Results of the Florissant Expedition of 1908," American Naturalist, Vol. XLII, pp. $560-581,1908$. 
and southern trees which do not now exist in the state at all. Among these others were: mulberry, soapberry, acacia, redbud and walnut. No doubt the climate was much warmer at that time and, in the mountains at least, more moist. The fossil imprints of many of the leaves are very perfect and the trees can be told with considerable certainty. We may be sure that for thousands and perhaps millions of

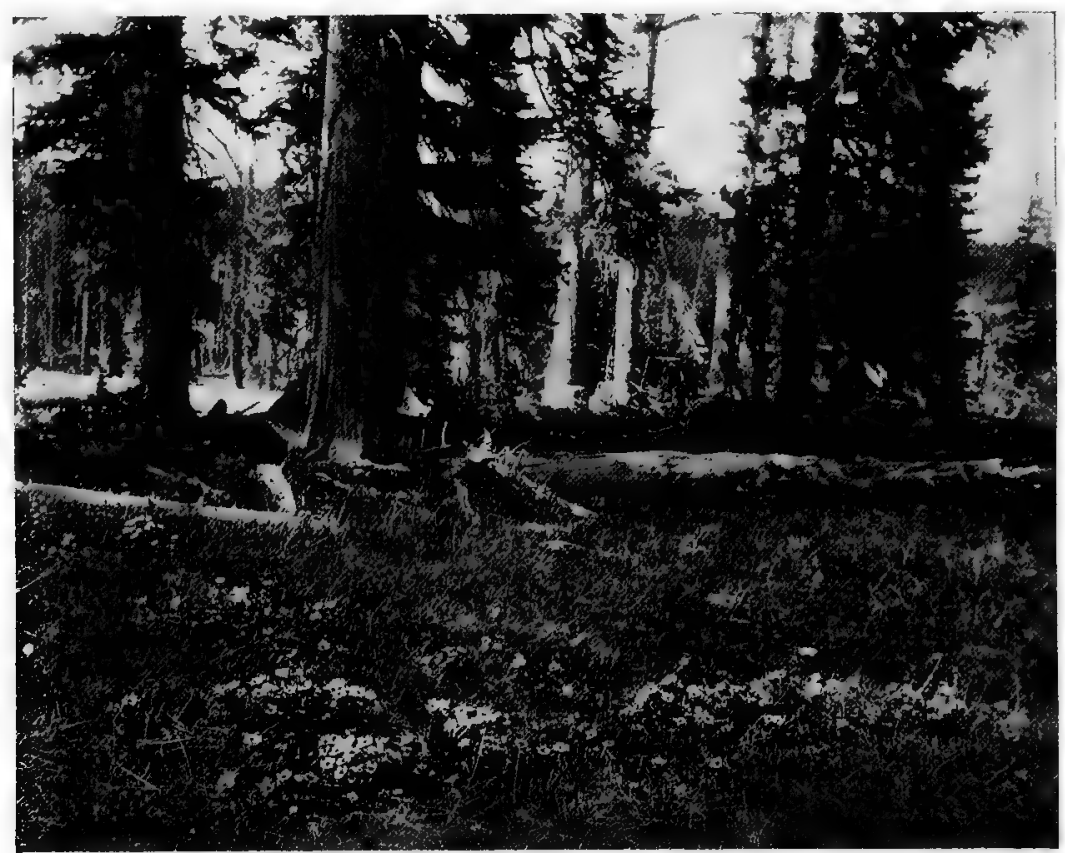

Fig. 41.-Sub-aline Forest of Englemann SPRUCe

years the pines, cottonwoods, cedars and thornapples have been an important part of the vegetation of this part of the world.

Literature dealing with Colorado trees.-The well-known manuals of botany of the eastern United States such as Gray's and Britton's, describe certain of the tree species of Colorado. So, also, the Rocky Mountain Botany $y^{x}$ by Professor John M. Coulter, issued many years

I A new edition of this work, rewritten by Professor Aven Nelson of the University of Wyoming, is to be issued in roro. 
ago, gives descriptions of a part of the arborescent flora of the state. Unfortunately there is no new work which gives all of the trees nor one which discusses the forest formations. Probably the most useful single book is the new vork of Dr. Britton. ${ }^{\mathrm{I}}$ Anyone interested in the larger aspects of forestry will find useful articles from time to time in the National Geographic Magazine and in the magazine, Conservation.

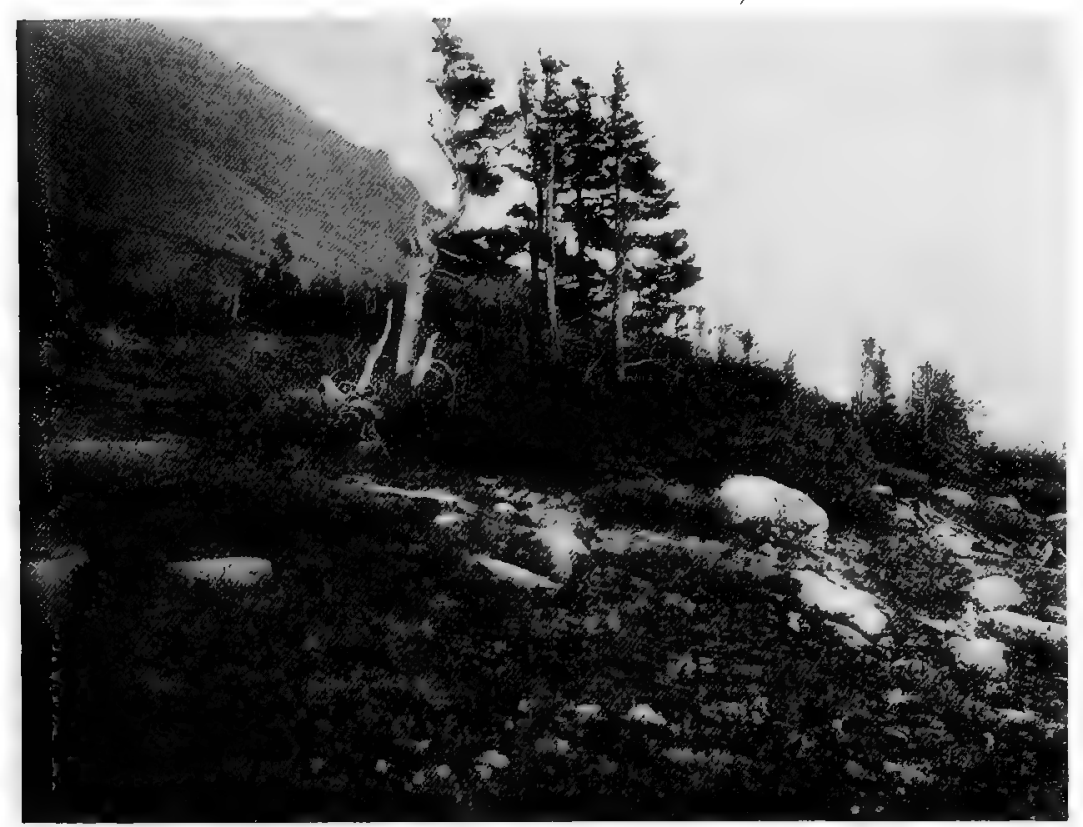

Fig. 42.-Sub-Alpine Scrub at Timbebline

This latter publication is the organ of the American Forestry Association. The Flora of Colo $a d o^{2}$ is valuable for the professional botanist-indeed it is a perfect mine of information-but is rather too technical in its treatment for the amateur. The present writer has made free use of this work in the preparation of his account of the tree species of Colorado. At the close of the present paper are noted some of the books and

× Britrow, N. L., North American Trees, pp. I-894, New York, 1908.

- Rydberc, P. A., Flora of Colorado, Bull. roo, Colo. Agric. Exper. Sta., pp. I-447, Ft. Collins, I go6. 
special articles which deal with Colorado trees. It is not intended as a complete bibliography, but merely as a useful working list for reference.

Economic considerations.- The great importance of forests is now recognized on every side and it is desirable that the people of Colorado should know something of the trees of the state and of their value. Perhaps the most important function of forests in mountain districts

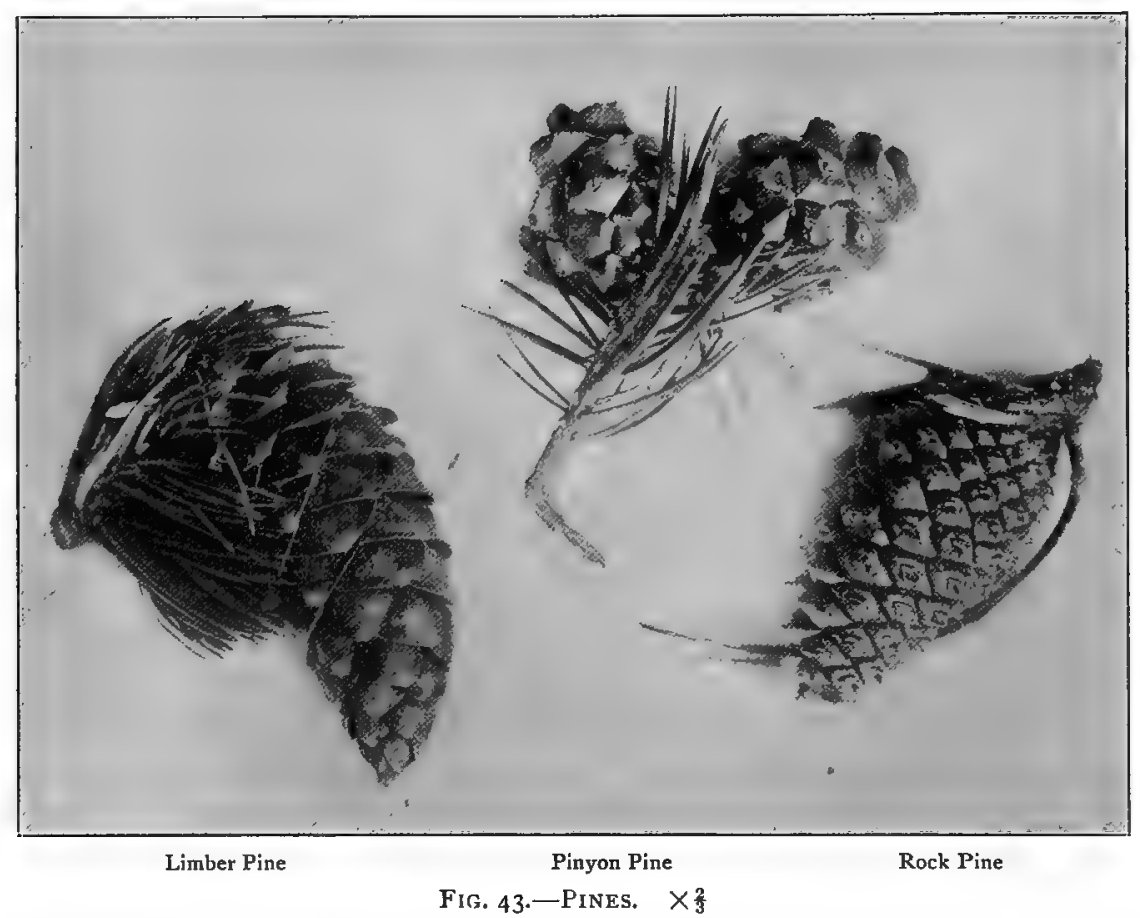

anywhere is to conserve the water and prevent the land from washing. But they may serve also to supply much needed timber for mining and manufacturing purposes. In many parts of the state large areas of the original forest have been cut and burned over so that there is now much waste land in the foothills and in the mountains. Since this is neither fit for mining nor agriculture it should, in time, come to be valuable for purposes of forest growth. For the most part, reproduction in the forests 
of Colorado is rapid and all that is needful to insure the reforestation of old lands is careful supervision and protection. It matters little from the standpoint of the botanist or one interested in forests how this protection is attained. It may be done either by federal or state authority. Private

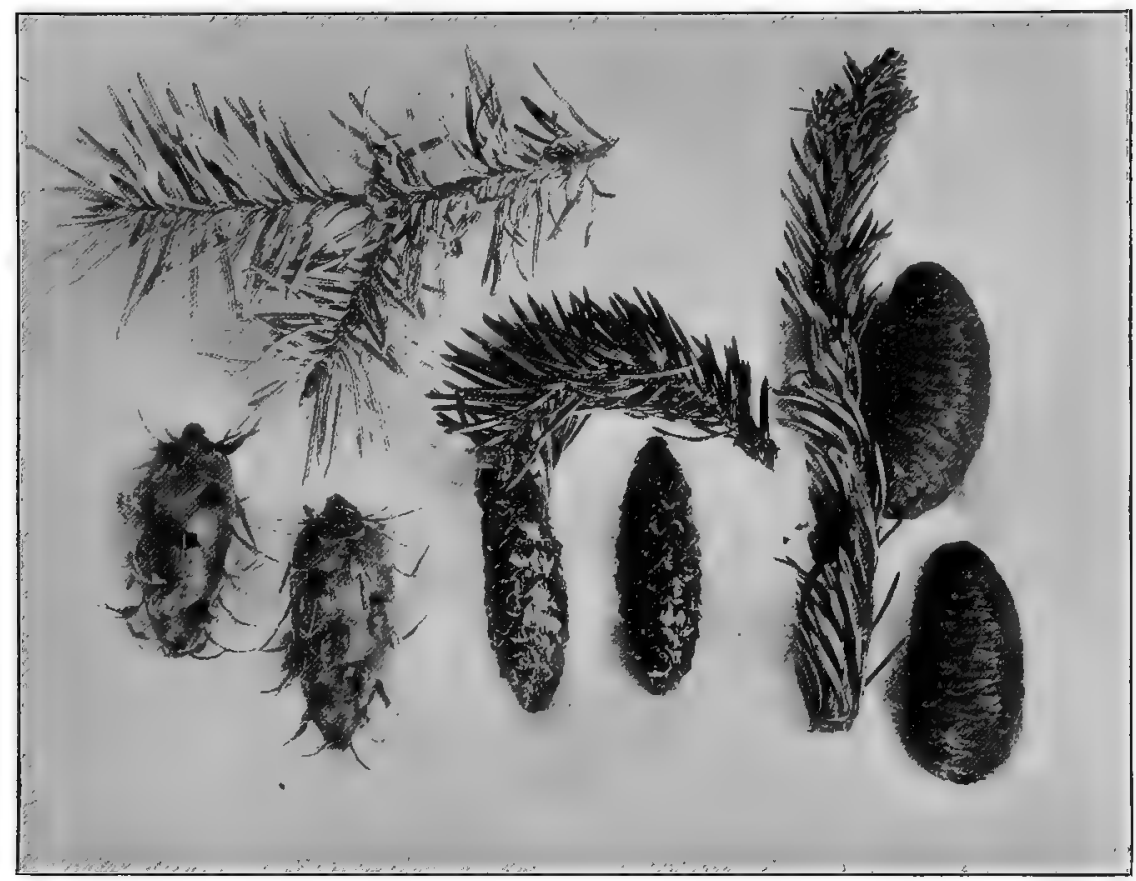

Dorglas Spruce

Engelmann Spruce

Sub-alpine Fir

FIG. 44.-SPRUCES AND FIR. $\times \frac{2}{3}$

supervision of forest lands elsewhere, at least, has not been successful. Not only must illegal cutting be prohibited but fires must be kept out. If this is attended to the forests will take care of themselves.

The waste and desolation which come in the wake of forest destruction is well known. France has spent millions of dollars in reforestation of mountain slopes. Spain, Greece, Turkey, northern Africa and China 
have suffered because there was no supervision of forests. Conditions in China have been recently described:

The ruthless destruction of the forests in northern China has brought about, or has aided in bringing about, desolation, just as the destruction of the forests in central Asia aided in bringing ruin to the once rich central Asian cities; just as the destruction of the forests in northern Africa helped toward the ruin of a region that was a fertile granary in Roman days. Short-sighted nuan, whether barbaric, semi-civilized, or what he may mistakenly regard as fully civilized, when he has destroyed the forests, has rendered certain the ultimate destruction of the land itself. . . . . This is just one of those matters which it is fatal to leave to unsupervised individual control. The forests can only be protected by the state, by the nation, and the liberty of action of individuals must be conditioned upon what the state or nation determines to be necessary for the common safety. ${ }^{\mathrm{r}}$

With the continued rise in the price of all kinds of wood the forests of Colorado may be made one of the great economic assets of the state in the future. They will serve for protection to the headwaters of our streams and if rightly managed will furnish a constant supply of timber for industrial and building purposes.

The cottonwoods of the gulches and river bottoms are, to a considerable extent, made use of for fences and for other rough construction work. If farmers and others would take pains to plant these and other more valuable trees they would secure profitable returns. Many of the smaller trees of the state are proving useful as shade trees and still others are being introduced into cultivation for ornamental purposes in parks and private grounds. The thornapples are especially promising as ornamental trees because of both flowers and fruit, while the cottonwoods, hackberries and box-elders are useful for shade.

Exotic trees.-A great many trees from other parts of the United States and from Europe have been planted in Colorado for their fruit or for shade and ornament. Apples and plums do well at the western edge of the great plains next the foothills, while in the Grand Valley, on the western slope, peaches are much grown. Most of the ordinary shade trees of the eastern United States may be grown at Denver; such as honey locust, black locust, elms, maples, ash, sycamore and catalpa. Trees planted for forest purposes are chiefly black locust, honey locust,

"Roosevelt, Theonore, "Message to the Congress of the United States," December 8, rgo8, 
black walnut and hardy catalpa. Rock pines are especially desirable for hillsides and in poor soil. The deciduous trees are more often planted in the fine-grained soil of the plains region. Unless grown on bottom lands all trees planted in Colorado must be irrigated or else well cultivated and protected during the first few years after being planted.

Scope of the present study.-The following pages are given up to keys for the determination of the species of trees in the state, together with a somewhat full account of each of the trees of the pine family. It was thought best to describe these trees in some detail on account of their economic value and the general interest which attaches to them. It is impossible at the present time to state fully the distribution of most of the species within the state. Only a small part of the area has been examined by botanists so that the limits of distribution are imperfectly known.

How to use the keys.-It is necessary to look at Key I for the "evergreens" (trees of the pine family) and at Key II for any other trees. In each of the keys two choices are open to the student at first, named respectively $\mathbf{I a}$ and $\mathbf{I b}$. These two are to be read carefully and whichever describes the tree under consideration will be used as the beginning of the classification. At the right of line is a figure in parenthesis which refers the user of the key to the next line which is to be consulted. This may give at once the desired name or it may refer to a still lower line. At any rate the process is to be continued until the name of the genus is found. Noting the number of the genus, as well as the name, the student should now turn to the proper place in the following pages and, with the aid of the special key, determine the exact species. Both the scientific and English names are given since both are likely to be useful to one interested in botany or forestry.

\section{KEY I. FOR IDENTIFICATION OF COLORADO EVERGREENS}

ra. Trees with needle-like foliage leaves; fruit a cone.

Ib. Trees with scale-like, overlapping leaves, fruit a small berry (cedars).

Genus 5. Sabina 
2a. Foliage leaves (needles) in bundles of two or more surrounded at base by a short sheath. Leaves mostly more than $25 \mathrm{~mm}$. (I in.) long. Cones hard and woody when mature.

2b. Foliage leaves (needles) solitary, not in bundles; mostly less than $25 \mathrm{~mm}$. (i in.) in length. Mature cones leathery or papery; not hard and woody.

(3)

3a. Leaves jointed near the base, the lower part of the leaf brown and woody and remaining on the branchlet after the rest of the leaf has fallen. Leaves in our species stiff and four-angled, not flat. Cones pendulous.

Genus 2. Picea

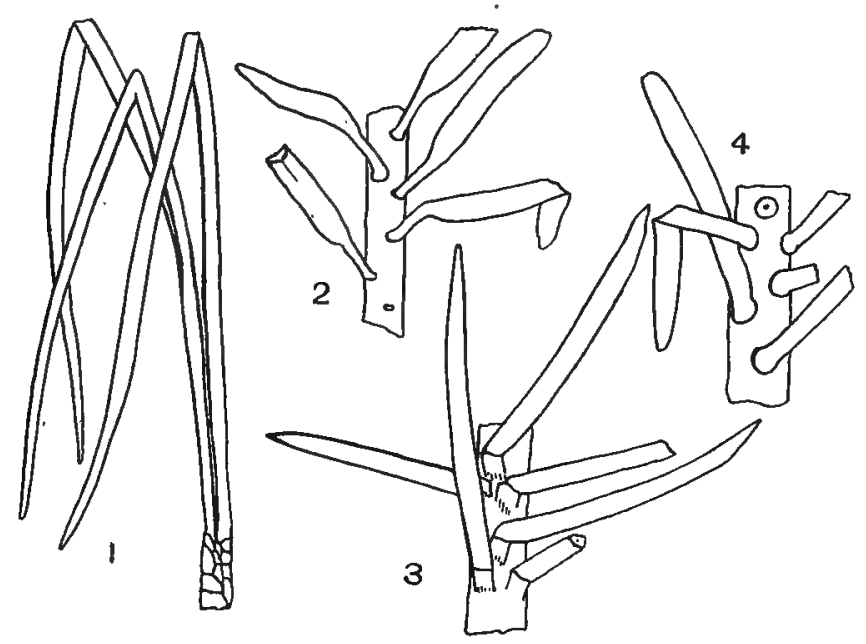

Fig. 45--Leaves of Coniferous Trees. I. Pine (Pinus); 2. Douglas Spruce (Pseudotsuga); 3. Spruce (Picea); 4. Fir (Abies).

3b. Leaves not brown nor woody at base, flat. When they fall off they leave a scar but no part of the leaf remains.

(4)

4a. Leaves rather soft; narrowed toward the base into a short stalk which broadens slightly at the point of attachment. Leaf-scars transversely elliptical. Cones pendulous, the projecting bracts three-pointed.

Genus 3. Pseudotsuga

4b. Leaves somewhat stiff, very slightly narrowed at base; leaf scars rather large, circular in outline. Cones erect, dark purple or blackish or sometimes yellow.

Genus 4. Abies

\section{KEY II. FOR IDENTIFICATION OF DECIDUOUS TREES}

Ia. Leaves simple; not composed of leaflets.

I b. Leaves compound; of three or more leaflets. 
2a. Trees without thorns or spines.

(3)

$\mathbf{2 b}$. Trees with thorns or spines.

3a. Trees with rough bark of bitter taste; leaves much longer than broad; flowers and fruits in erect catkins; seeds cottony (willows).

Genus 7. Salix

3b. Trees with white or light gray branches; flowers and fruits in drooping catkins; seeds cottony (cottonwoods, poplars and aspen).

Genus 6. Populus

3c. Trees with conspicuous flowers and fleshy fruits (cherry, plum and June berry).

3d. Trees not falling under $3 \mathrm{a}, \mathbf{3 b}$ or $3 \mathrm{c}$.

4a. Leaves with margin finely toothed all around (plum and cherry). Genus I5. Prúnus

4b. Leaves with margin toothed only in the upper half (June berry).

Genus I3. Amelanchier

5a. Leaves with veining pinnate; a distinct mid-rib with lateral veins extending from it.

5b. Leaves with palmate veining; the main veins extending from the base of the leafblade like fingers from the palm of the hand (maples).

Genus I 7. Acer

6a. Leaves elm-like; not symmetrical at base (hackberry).

6b. Leaves not elm-like; usually symmetrical at base.

Genus II. Celtis

7a. Leaves very small; only $\mathrm{I}_{5}$ to $25 \mathrm{~mm}$. ( $\frac{5}{8}$ to $\mathrm{I} \mathrm{in}$.) long (mountain mahogany).

7b. Leaves mostly $35 \mathrm{~mm}$. ( $\mathrm{r} \frac{3}{8} \mathrm{in}$.) long, or longer.

Genus I 2. Cercocarpus

8a. Leaves pinnately lobed or cleft; the lobes and sinuses rounded; fruit an acorn (oaks).

Genus Io. Quercus

8b. Leaves merely toothed or slightly sharp-lobed; flowers and fruits in catkins (alders and birches).

8c. Leaves finely toothed or nearly entire; fruit berry-like, in small clusters (cascara sagrada).

Genus rg. Rhamnus

8d. Leaves finely toothed or wavy margined; fruit a winged samara (ash).

Genus 20. Fraxinus

9a. Leaves rough and coarse; with both fine and coarse teeth (alder). Genus 9. Alnus

9b. Leaves rather smooth; bright green.

Genus 8. Betula

roa. Spines numerous, sharp pointed (thornapple).

Iob. Spines few, scattered (plum).

Genus I 4. Crataegus

Genus $5_{5}$ Prunus

I Ia. Trees with short thorns in pairs (locust).

Genus I6. Robinia

I Ib. Trees without thorns; leaflets more than four pairs (sumac).

Genus I8. Rhus

I Ic. Trees without thorns; leaflets 3,5 or 7 (box-elder).

Genus I 7. Acer

\section{DESCRIPTIONS AND KEYS TO SPECIES}

Genus I. PINUS, PINE

Evergreen trees and shrubs growing often in dry and rocky situations. Foliage leaves needle-shaped growing usually in bundles of 2 to 5 
leaves. The foliage leaves are borne on very short twigs (dwarf shoots), which arise in the axils of appressed scale leaves. Staminate cones small, yellow or reddish, growing in clusters and shedding their pollen in late spring or early summer. Carpellate cones either solitary or clustered. Cone scales thick, becoming woody. The cones ripen the second year or later.

Ia. Leaves in bundles of 4 to 6; medium-sized or small trees, chiefly in high altitudes.

Ib. Leaves in bundles of 2 or 3 .

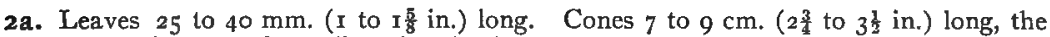
scales with curved, needle-pointed spines.

Pinus aristata

2b. Leaves 3.5 to $7.5 \mathrm{~cm}$. (I to 3 in.) long. Tree of wind-swept mountain sides or exposed points. Cones large, 7 to $25 \mathrm{~cm}$. (23 to $9 \frac{3}{4}$ in.) long, the scales smooth, without spines

Pinus flexilis

3a. Leaves short, 2 to $4 \mathrm{~cm}$. (童 to $\mathrm{I}$ in.) long, generally in pairs; cones small, about the same length as the leaves, seeds large (about the size of a common white bean), edible. A tree or shrub found in the foothills south and west.

Pinus edulis

3b. Leaves longer, 4 to $12 \mathrm{~cm}$. ( $\mathrm{I} \frac{1}{2}$ to $4 \frac{3}{4}$ in.) long; in bundles of 2 or 3 .

4a. Leaves usually about $10 \mathrm{~cm}$. ( $3 \frac{7}{8} \mathrm{in}$.) long, but shorter in exposed situations; sometimes longer. Cones 6 to $9 \mathrm{~cm}$. ( $2 \frac{3}{8}$ to $3 \frac{1}{2}$ in.). A tree of foothills and river bluffs and extending occasionally to an altitude of ro,000 ft. Pinus scopulorum

4b. Leaves 3 to $6 \mathrm{~cm}$. ( $1 \frac{1}{4}$ to $2 \frac{3}{8} \mathrm{in}$.) long; cones about same length as leaves. A tree of foothills and mountains, often forming pure forests at altitudes of 8,000 to I0,000 ft.

Pinus murrayana

Pinus aristata Engelm. Bristle-CONe Pine. Leaves in bundles of 4 or 5 , dark green, 2.5 to $4 \mathrm{~cm}$. long. Cone 7 to $9 \mathrm{~cm}$. long. Cone scales somewhat thin, each with a slender curved bristle about $6 \mathrm{~mm}$. long. Seeds winged.

A bushy tree of small or medium size with the main trunk short, numerous strong branches starting rather low down. Bark thin, pale or milky white on small branchlets, dark gray or brown on the main trunk. Wood soft and not durable; specific gravity 0.5572 .

Rocky and gravelly slopes at high altitudes in the mountains from central and southern Colorado to Utah, Nevada, southern California and Arizona.

Pinus flexilis James. Limber Pine, White Prne. Leaves in bundles of 5; stout, rigid, dark green, 3.5 to $7.5 \mathrm{~cm}$. long. Cone very large, 7 to $25 \mathrm{~cm}$. long. Cone scales smooth, without bristle points. Seeds large, with a narrow wing which usually adheres to the cone scale when the seeds drop.

A medium-sized tree with a short main trunk and abundant lateral branches, growing in wind-swept situations and hence often much distorted. Bark of twigs and branches pale gray or whitish, becoming dark brown on older trunks. Wood light; specific gravity $0.435^{8}$; sometimes used for lumber which is, however, full of knots. 
Eastern slope of Rocky Mountains from Alberta to western Texas, westward through Montana to Nevada and California. It is the principal tree of the upper foothills of the eastern slope in Montana. In Nevada it forms extensive forests. In Colorado and Wyoming it is usually scattered in exposed situations at rather high altitudes but a few trees are found on the bluffs west of Pawnee Buttes, Colo., at an altitude of 5,00c feet.

Pinus edulis Engelm. Pinyon, Nut Pine. Leaves in bundles of 2 , rarely 3 ; dark green, curved, stiff, 2 to $4 \mathrm{~cm}$. long. Cone when mature about the same length as the leaves and nearly spherical; cone scales few, thick, spiny tipped. Seeds large, about the size of a small white bean, the narrow wing of the seed remaining adherent to the cone scale when the seed falls.

A small or medium-sized tree, much branched and shrublike. Bark rather thin; that of young branchlets orange colored, becoming at length gray or brown. Wood rather durable; specific gravity 0.6388 ; brittle, close grained. Used for fuel and fencing and sometimes for preparation of charcoal. In western Texas it has been sawed for lumber. The large, edible seeds, known as "pinyon nuts," collected by Indians, are on sale by fruit dealers in the towns and cities of Colorado.

Eastern foothills of the outer range of the Rocky Mountains from near the Palmer Lake divide south to western Texas and west to Arizona and southwestern Wyoming. In places it forms open forests with the rock pine; mixed with cedars it is common on the hills and table lands of western Colorado. It does not extend to very high altitudes.

Pinus scopulorum (Engelm.) Lemmon. Rock PINE. Leaves in bundles of two or three, variable as to number even on the same tree; stout, dark yellowish-green, often in bottle-brush arrangement at the ends of naked branches; 8 to $15 \mathrm{~cm}$. long. Cone 6 to $9 \mathrm{~cm}$. long, the cone scales each with a stout sharp prickle. The young cones are erect the first summer; when fully grown they are horizontal or slightly declining.

A handsome spreading tree, the largest of our pines, with thick, deeply-furrowed, reddish bark becoming very thick on old trees. Wood hard and strong but differing greatly in quality; where abundant it is sawed into lumber or used for railway ties and mine timbers. The specific gravity is $0.46 \mathrm{rg}$.

Hills and ridges of western Nebraska to Rocky Mountain region and from Montana to Arizona and New Mexico.

On account of its resistance to drought this tree should be a valuable one for planting in semi-arid districts. The large seeds germinate freely and the trees are easily grown when given reasonable care. Sometimes called "yellow pine" or "blackjack."

Pinus murrayana "Oreg. Com." Lodgepole Pine. Leaves in bundles of 2, yellow-green, 3 to $6 \mathrm{~cm}$. long. Cone about the same length as the leaves, very persistent, often remaining attached three or four years after ripening; cone scales with short, sharp prickles.

A tall, straight tree, generally growing in dense groves on north slopes in the higher foothills. The trees have been considered of little value for lumber but they are certainly most useful in holding the soil and in protecting snow from too rapid melting. Seeds of this pine, unlike those of most species, retain their vitality for a number of years. Burned districts become reseeded by the opening of the cones which takes place on account of the heat produced by the fire. Wood rather light and soft, not durable; specific gravity 0.4096 . Used to some extent for ties, mine timber and fuel when better wood is not available. 
Recently developed methods of seasoning and preservative treatment promise to make the lodgepole pine valuable for railway ties and mine timbers.

Montana to southern Colorado, west to California and Alaska. In the higher foothills of Colorado.

\section{Genus 2. PICEA, The True Spruces}

Tall, conical, evergreen trees with tapering trunk and thin, scaly bark. Leaves needle-shaped, four-angled or flattened (ours fourangled) with sharp points. The leaves extend out from all sides of the twig in bottle-brush fashion; they are not in bundles as in pine but occur singly. Leaves jointed near the base, the lower part (sterigma) becoming woody and persistent after the fall of the leaf. Bare twigs thus appear roughened with short, truncate elevations. Cones pendant, chiefly on the upper branches.

ra. Leaves rigid, needle pointed, blue-green or silvery, branchlets smooth or at least not hairy. Cones about $7 \mathrm{~cm}$. $\left(2 \frac{3}{4} \mathrm{in}\right.$.) long. Frequent in cultivation. Picea parryana

Ib. Leaves less rigid, abruplly pointed, having a somewhat skunk-like odor when bruised. The branchlets are generally described as pubescent but are smooth in specimens grown at high altitudes. Cones about $4 \mathrm{~cm}$. (I

Picea engelmanni

Picea parryana (Andree) Sarg. Colorado BluE Spruce. Leaves stout, rigid, four-angled, mostly 25 to $30 \mathrm{~mm}$. long but on cone-bearing branches shorter and curved. Generally the leaves stand out from all sides of the branchlets but sometimes the under surface of horizontal branches has few leaves. Color of leaves generally silvery or bluish-green when young, becoming duller with age. Individual specimens differ greatly in this regard. Cones about $7 \mathrm{~cm}$. long.

A tree of medium size. Bark broken into small oblong, platelike scales; on old trunks thick and deeply grooved. Wood light, soft, weak; specific gravity 0.3740 .

Along the mountain streams of eastern Colorado, west to Utah and north to the Wind River Mountains of Wyoming, occurring singly or in small groves.

Much cultivated for ornament in this country and in Europe. There are numerous horticultural varieties propagated by grafting.

Picea engelmanni (Parry) Engelm. Engelmann SpRuce. Leaves ridged above and below so that they are rather four-sided; awl pointed; not so stiff as those of the blue spruce. Leaves at first covered with a bluish or silvery bloom which disappears later; slender, 25 to $30 \mathrm{~mm}$. long on the ordinary branches but shorter on cone-bearing twigs. Cones 3 to $5 \mathrm{~cm}$. long.

A large conical tree of the higher foothills and inountains; near timber limit a straggling, prostrate shrub. Bark thin, broken into large, thin, loose scales. Wood light, soft, close grained, not strong; specific gravity 0.3449 . Frequently used for lumber and for making charcoal. The bark has been employed for tanning leather. In some localities the Englemann spruce has been largely cut for railway ties and to some extent for telegraph and telephone poles. It should be valuable for wood pulp. 
In the Cascade, Selkirk and Rocky Mountain ranges of British Columbia and Alberta, south through the mountain states to New Mexico and Arizona, west to Oregon. It is by far the more abundant of our two species of Picea and is the common tree near timberline where it forms scrubby mats. In such situations it seldom bears cones. At 10,000 to $\mathrm{I}$ I,, 00 feet altitude it reaches its largest size.

The Engelmann spruce has been planted for ornament in the eastern United States and in Europe. Sometimes it is mistaken for the blue spruce. These two species of Picea are not easily distinguished; however, the size of the cones is a marked feature.

\section{Genus 3. PSEUdotsuga, Douglaś Spruce}

Tall conical trees with thick, furrowed bark and strong wood resembling in quality the best hard pine. Branches generally ascending, the branchlets spreading; general appearance more feathery than true spruce. Leaves linear, flat, narrowed at base to a short leaf-stalk. Cones pendant; usually scattered over the tree; not confined to the upper branches; cone scales persistent; bracts with prominent teeth giving the cone a fringed appearance. Three species of this genus are known; one in Japan, two in western North America.

Pseudotsuga mucronata (Raf.) Sudw. Douglas SpRuce. Leaves rather soft, not rigid, flat, channeled above and ridged below, 20 to $35 \mathrm{~mm}$. long, dark yellow-green in color, narrowed to a short stalk; leaf scars not prominent. Cones pendulous, 5 to $10 \mathrm{~cm}$. long, the bracts projecting beyond the scales. Each bract with two lateral teeth and the midrib projected as a rigid awn.

A tree of handsome conical form, especially when young; reaching the greatest size in the moist forests of Oregon and Washington. Bark on young trees smooth and thin; on older trees very thick and deeply furrowed. Wood hard; light red or yellow; specific gravity 0.5 I57; largely manufactured into lumber in the Pacific Northwest where it is generally known as "Oregon pine," "Douglas fir" and "red fir." Employed for fuel, railway ties and piles; in Colorado used as Christmas trees."

British Columbia and Alberta southward through hills and mountains to northern Mexico and western Texas.

Frequently planted as an ornamental and shade tree in Europe and the eastern United States. Numerous varieties are distinguished in cultivation.

\section{Genus 4. ABIES, The Firs, Balsams}

Tall conical trees of colder regions and mountain districts. Leaves linear, flat, sessile; grooved above and having a notched apex. On the upper cone-bearing branches the leaves are often curved and thick, with the upper surface convex instead of grooved. Cones erect; purplishblack or yellow, formed of closely overlapping scales; exuding a bal- 
samic resin. The cone-scales and bracts separate from the axis while this is still on the tree; hence complete cones are never found under the trees.

Ia. Leaves of vigorous lower branches 2.5 to $4.5 \mathrm{~cm}$. (I to $1 \frac{3}{4}$ in.) long; resin ducts of the leaves deeply imbedded, not close to the epidermis. Cones purple or nearly black.

Abies lasiocarpa

Ib. Leaves of vigorous lower branches 4.5 to $7.5 \mathrm{~cm}$. ( $1 \frac{3}{4}$ to $3 \mathrm{in}$.) long; resin ducts of the leaves close to the epidermis of the under surface; cones yellow, green or purple. Not found in northern Colorado.

Abies concolor

Abies lasiocarpa (Hook.) Nutt. Sub-Alpine Frr. Leaves flat, with prominent mid-vein, bluish-green; on vigorous lower branches 2.5 to $4.5 \mathrm{~cm}$. long; on old parts and on cone-bearing twigs much shorter. Cone oblong-cylindrical, rounded, erect, purple or nearly black, 6 to $10 \mathrm{~cm}$. long.

A medium-sized tree with branches extending nearly to the base of the trunk; bark of young trees pale gray and smooth; on old trees broken with shallow fissures and roughened with thin orange-colored scales. Wood light, not strong, nor durable; of little value but sometimes used as firewood; specific gravity 0.3476 .

High altitudes in the mountains throughout western North America.

Abies concolor Lindl. WhIte FIR. Leaves mostly in two rows on the branchlets, more or less erect; on lower branches flat, straight, with rounded or pointed apex; length 4.5 to $7.5 \mathrm{~cm}$.; on cone-bearing twigs shorter and generally curved. Cone ellipsoidcylindrical, 7 to $3 \mathrm{~cm}$. long, grayish-green, purple or yellow, with broad, closely imbricated scales. A large tree with narrow spire-like crown; the short, main branches bearing long, lateral branchlets; the whole forming frond-like masses of foliage. Bark of old trunks becoming very thick, deeply divided into broad, rounded ridges. Wood light, close grained, not strong nor durable; specific gravity 0.3638 .

From the Pike's Peak region of the Rocky Mountains of Colorado west to Oregon and south to northern Mexico and Arizona, reaching its greatest development in the Sierras of California. It is the only true fir in the arid regions of the Great Basin.

\section{Genus 5. SABINA, Cedar}

The trees and shrubs of this genus are often classified with the junipers and placed in the genus I wniperus. It seems best to separate them because the cedars have such a very different general appearance. Leaves of true junipers are sharp-pointed and axr-shaped; instead of being scale-like and rather soft to the touch, as are the leaves of cedars. It is to be noted, however, that the leaves of young cedars are sharppointed and look like the leaves of junipers.

1a. Fruit when ripe blue, juicy, resinous.

Ib. Fruit when ripe reddish-brown, dry, fibrous. Small tree of western Colorado and westward. 
2a. Leaves with minute teeth near the apex; fruit generally one-seeded.

Sabina monosperma (Engelm.) Rydb.

2b. Leaves entire at apex; fruit generally several-seeded. The common cedar of the eastern slope. Sabina scopulorum (Sarg.) Rydb.

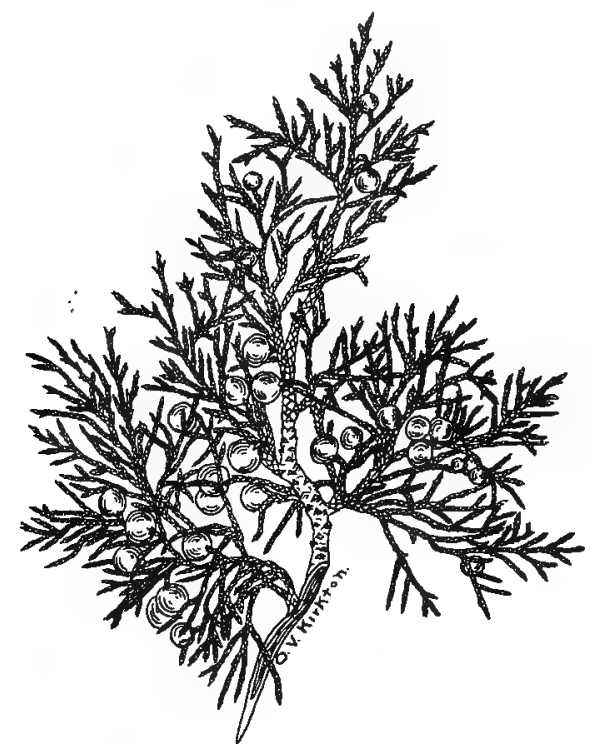

Fig. 46.-Rocky Mountain Red Cedar (Sabina scopulorum). $\times \frac{1}{2}$

Genus 6. Populus, Poplars, Cottonwoods, Aspen

These are the most important trees of the river-bottom and canyon forests. The broadleaf cottonwoods seldom extend far up the canyons and the narrowleaf trees seldom get down to the lower altitudes of the plains region.

Ia. Leaf-stalk much flattened laterally where attached to blade of leaf. Leaves easily rustled by the wind.

Ib. Leaf-stalk nearly cylindrical where attached to blade.

2a. Leaf-blade somewhat circular in outline with short-pointed apex. Bark very white. Populus tremuloides Michx. "Quaking Aspen"

2b. Leaf-blade broadly triangular or heart-shaped; marginal teeth less than ten on each side of blade (tree of southern Colorado).

Populus wislizeni (Wats.) Sarg.

"Broadleaf Cottonwood"

2c. Leaf-blade broadly triangular or heart-shaped; marginal teeth more than ten on each side of blade. (This is the common broadleaf cottonwood at Denver and in northern Colorado.)

Populus sargentii Dode. "Broadleaf Cottonwood" 

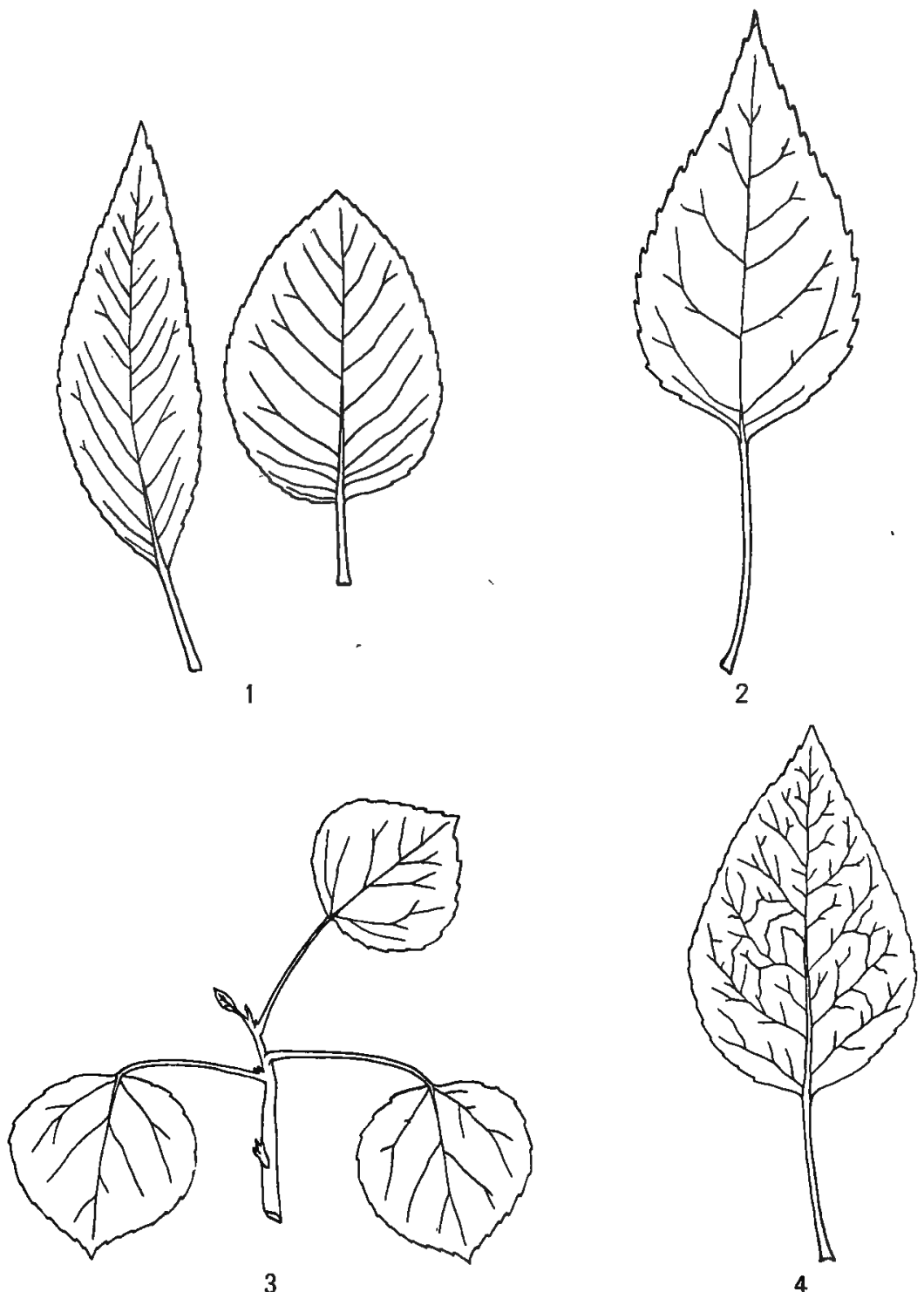

Fig. 47.-Leaves of Different Species of Populus $\left(X \frac{1}{2}\right)$

I. Populus angustifolia

3. Populus tremuloides

2. Populus acuminata

4. Populus halsamifera 


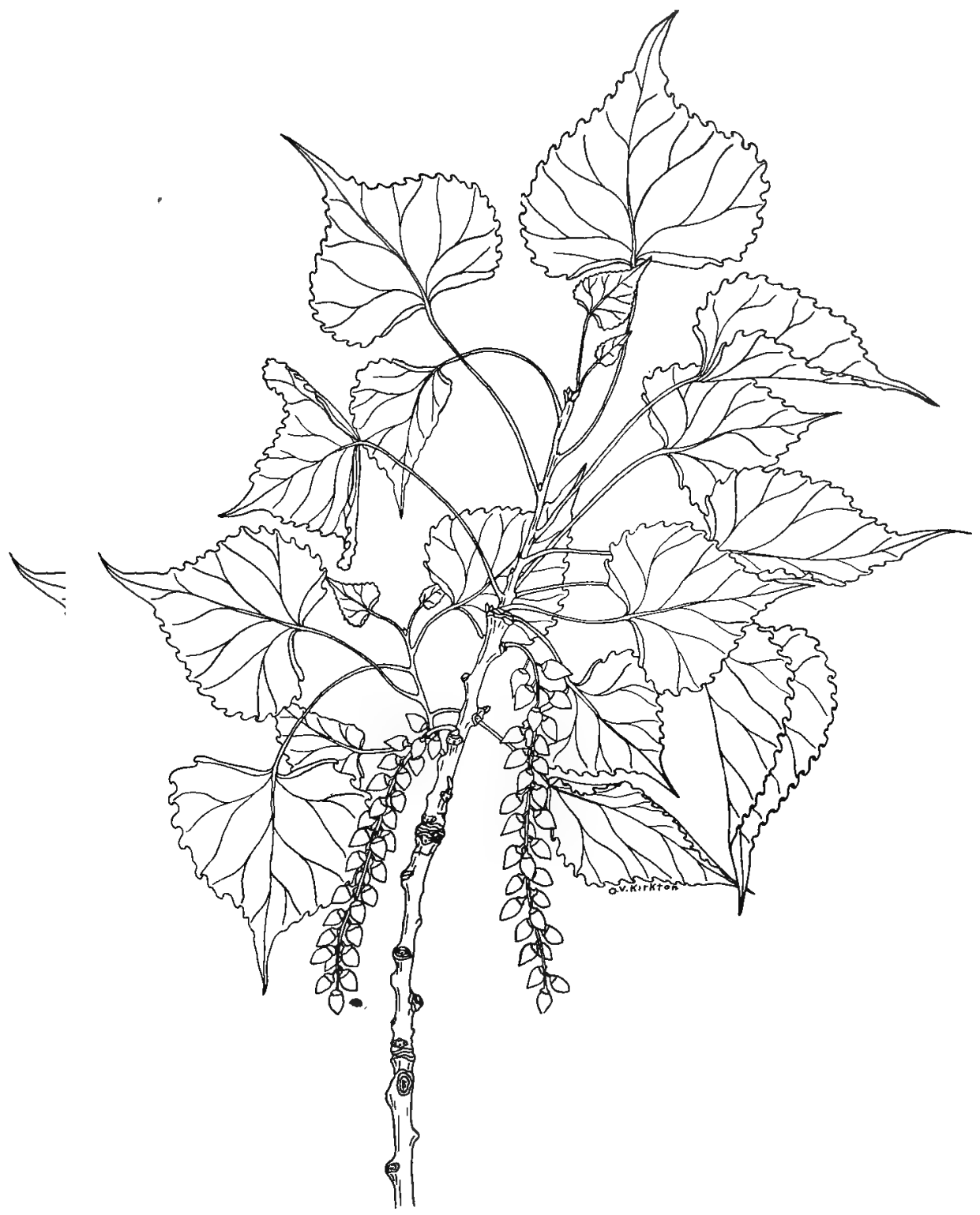

Fig. 48.-Broadleaf Cottonwood (Populus sargentii). $\times \frac{1}{2}$ 
3a. Leaf-stalk stout; one-third the length of blade or less; blades narrow.

Populus angustifolia James.

"Narrowleaf Cottonwood"

3b. Leaf-stalk slender, one-half the length of blade or longer.

(4)

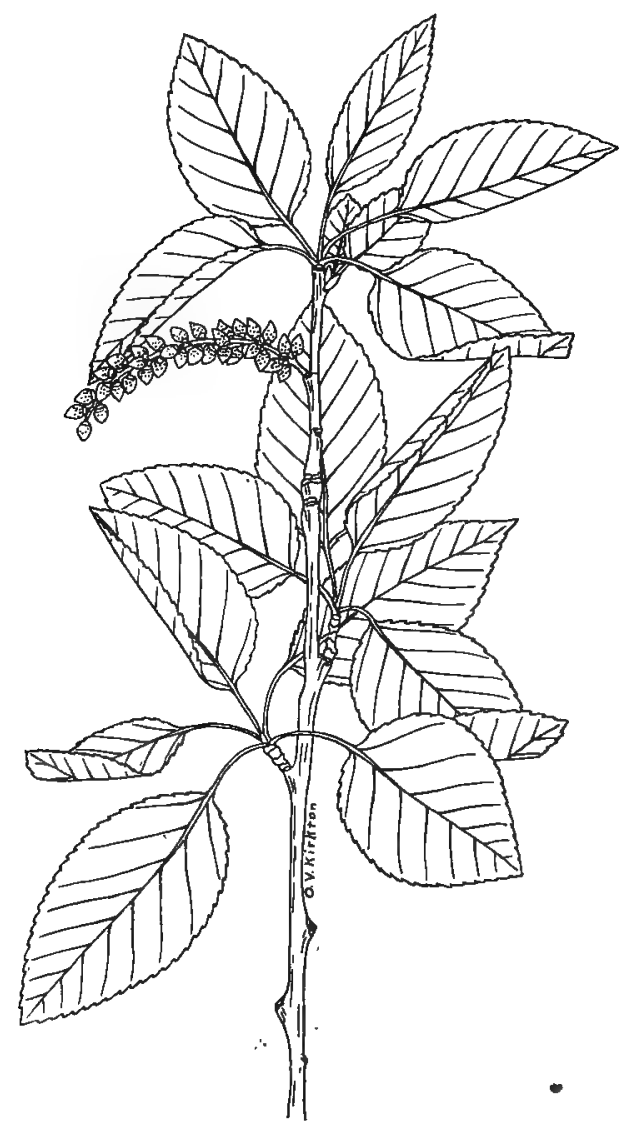

Fig. 49.-NARrowleaf CotTonwoon (Populus angustifolia). $\times \frac{1}{2}$

4a. Leaf-blades ovate; rounded at base, under surface whitish; veins prominent. Trees of mountain districts.

Populus balsamifera Linn. "Balsam Poplar"

4b. Leaf-blades lance-ovate, generally narrowed at base. Tree of canyons and the plains region.

Populus acuminata Rydb. "Lanceleaf Cottonwood" 


\section{Genus 7. SALIX, WILLOW}

In addition to the trees here listed there are about twenty species of shrubs in Colorado belonging to the genus Salix. Some of these extend above timberline, forming, in places, dense thickets three or four feet high.

ra. Leaves-lanceolate, finely serrate, pointed.

Ib. Leaves ovate, finely toothed or nearly entire, sometimes lance-elliptic or ob-ovate.

Ic. Leaves linear or narrowly lanceolate, silvery, at least when young.

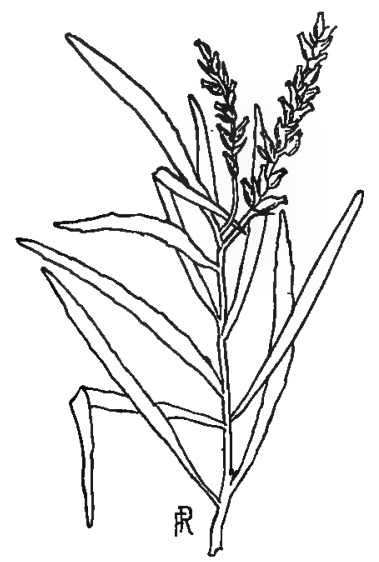

Fig. 50.-NARRowleaf Willow (Salix exigua). $\times \frac{1}{2}$

2a. Young twigs usually hairy; leaves firm.

2b. Young twigs smooth; leaves thin.

3a. Upper surface of leaves dark green; lower surface pale.

3b. Upper surface of leaves pale; lower surface dull.

4a. Capsule glabrous when mature.

4b. Capsule densely white-silky, even when mature.
Salix lasiandra Benth. "Western Black Willow" Salix amygdaloides Anders. "Peach Willow"

Salix nuttallii Sarg. "Nuttall's Willow"

Salix bebbiana Sarg. "Bebb's Willow"

Salix exigua Nutt. "Narrowleaf Willow"

Salix sessilifolia Nutt. "Narrowleaf Willow"

Genus 8. BETULA, Birch

In addition to the two trees of this genus there is a dwarf shrub (Betula glandulosa Michx.) along streams at high altitudes. 
ra. Bark of trunk brownish-gray; fertile catkins about $\mathrm{I}_{5} \mathrm{~mm}$. (童 in.) long.

Betula fontinalis Sarg. "Canyon Birch"

Ib. Bark of trunk pale gray or light brownish; fertile catkins about $30 \mathrm{~mm}$. (I 1 in.) long.

Betula andrewsii A. Nels. "Andrews' Birch"

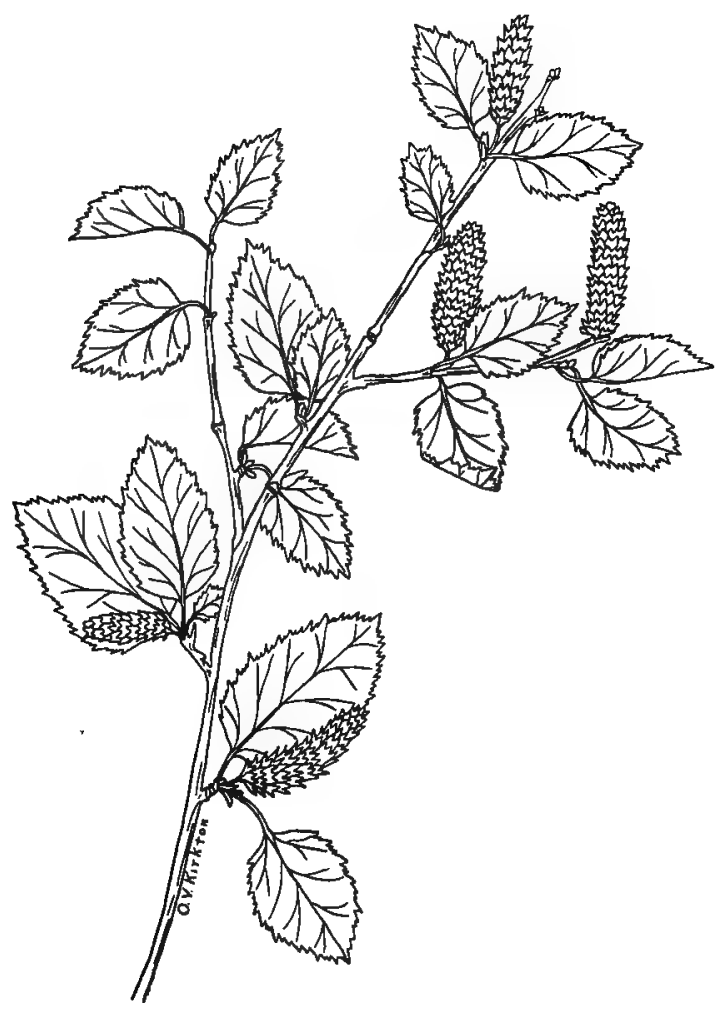

FIG. 51.-CANYoN BIRCh (Betula fontinalis). $\times \frac{1}{2}$

\section{Genus 9. ALNUS, ALDER}

This genus is represented by a single species, a tree or shrub growing in clumps along streams. Leaves broadly ovate, doubly toothed. 


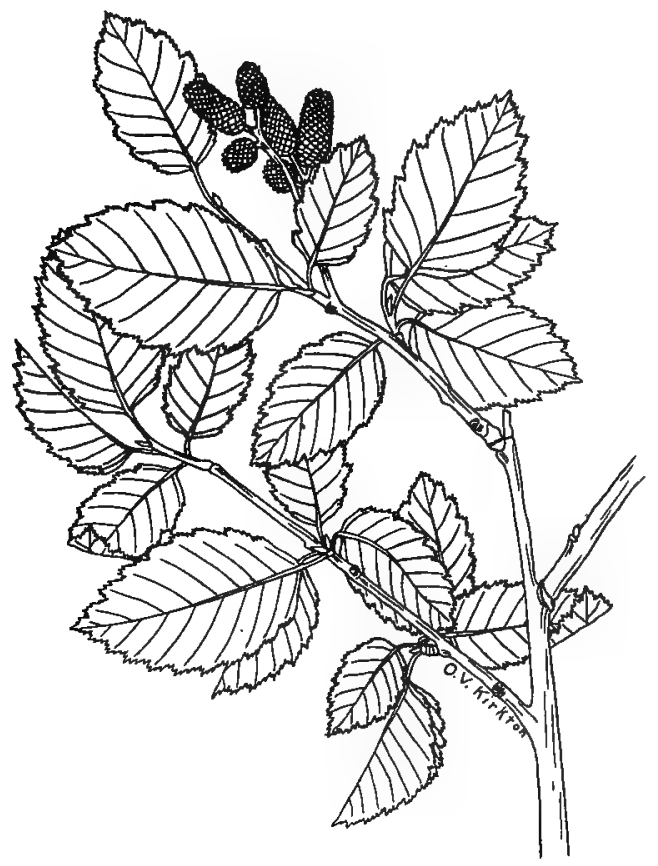

Fig. 52.-ALder (Alnus tenuifolia). $\times \frac{1}{2}$

Genus Io. QUERCUS, OAK

Eleven species of oak are recorded by Rydberg as occurring in Colorado. They are found in the foothill districts at moderate altitudes, chiefly in the southern and western parts of the state. The following are the only trees.

Ia. Leaves at maturity velvety beneath.

Quercus utahensis (DC.) Rydb. "Utah Oalk"

Ib. Leaves at maturity smooth or downy but never velvety beneath.

2a. Mature !eaves very thin.

Quercus leptophylla Rydb.

2b. Mature leaves firm.

"Colorado Oak" 
3a. Leaves ob-ovate in outline; cleft half-way to the mid-rib or less; acorns acute.

Quercus gambellii ${ }^{\text {Nutt. }}$ "Gambell's Oāk"

3b. Leaves ob-ovate in outline; cleft deeper than half-way to the mid-rib; acorns obtuse.

Quercus nitescens Rydh. "Shining Oak"

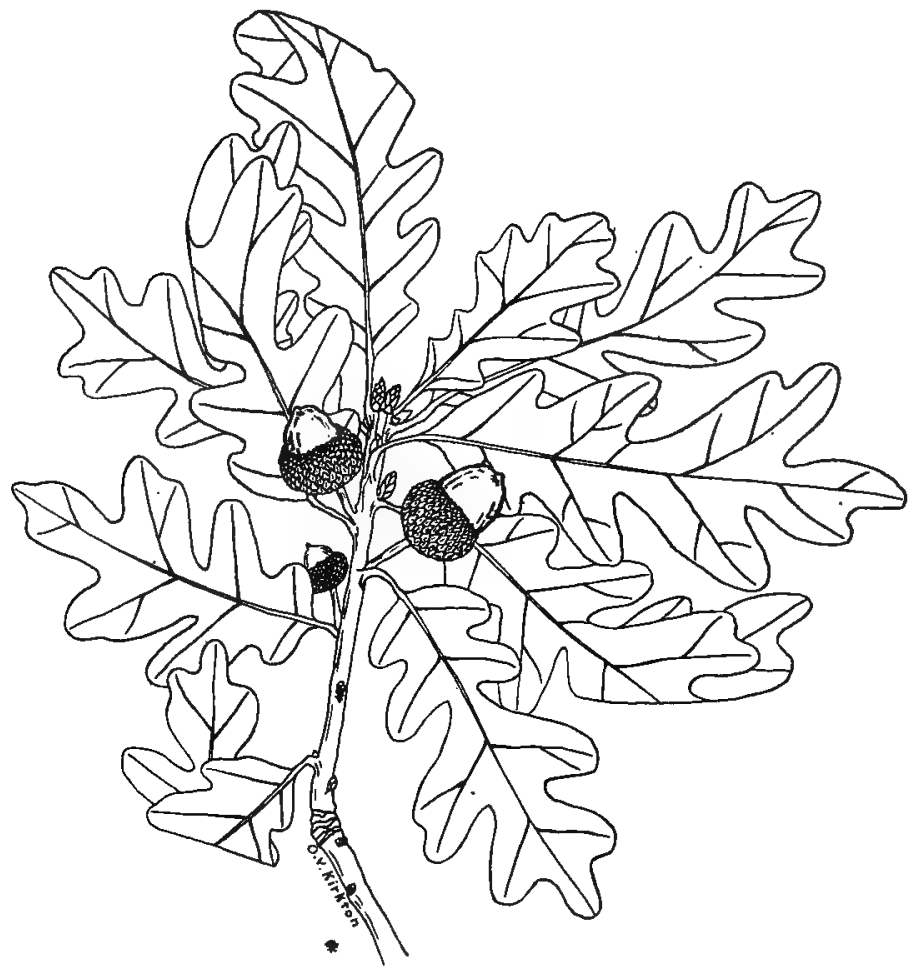

Fig. 53.-Shining OAK (Quercus nitescens). $\times \frac{1}{2}$

Genus i I. CELTIS, HackberRy

These trees have much the appearance of elms. The leaves ${ }^{-}$are oblique at base and the trunk is rough and deeply furrowed.

I u. Leaves broadly ovate; acute or short pointed at apex; ripe fruit red.

Celtis reticulata Torr.

"Thick-leaved Hackberry"

rb. Leaves ovate, often long pointed at apex; ripe fruit black. Celtis douglasii Planch. "Douglas Hackberry" 


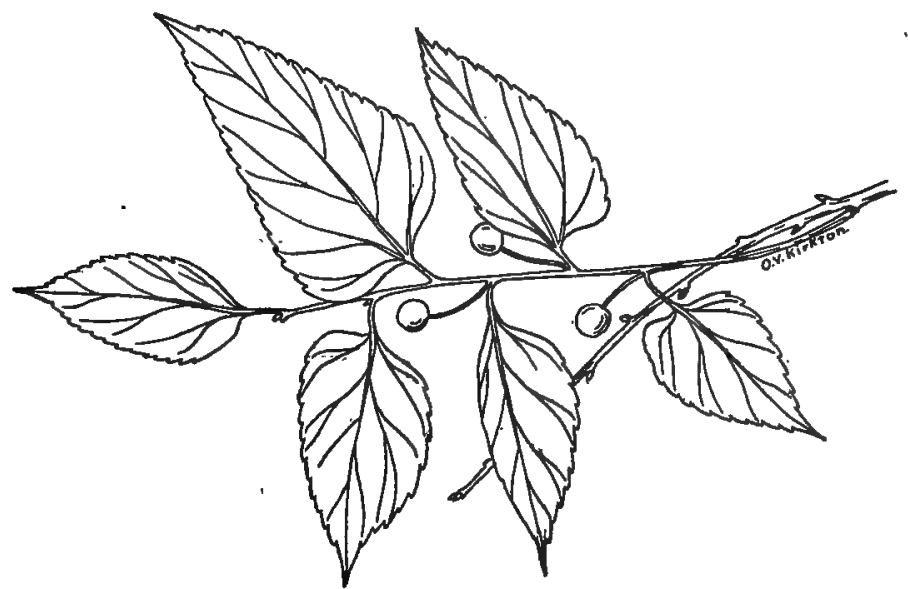

Fig. 54. -Thick-LEAved HackberRy (Celtis recticulata). $\times$

Genus r2. CERCoCaRPUS, Mountain Mahogany

In addition to the species named below there is a shrubby Cercocarpus which has dentate leaves; very abundant on the rock ridges and lower foothills east of the divide.

ra. Tree or shrub with very small entire leaves; fruit seed-like with long plumose tail. $i=$ Found on the western slope of the Rocky Mountains. Cercocarpus ledifolius Nutt.

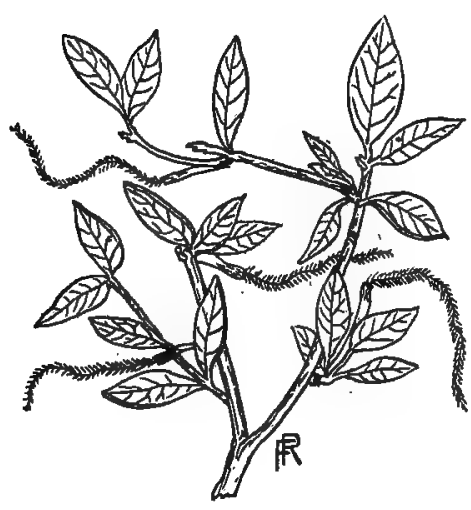

Fig. 55--MoUntaIN MAHOganY (Cercocarpus ledifolius). $\times \frac{1}{2}$.

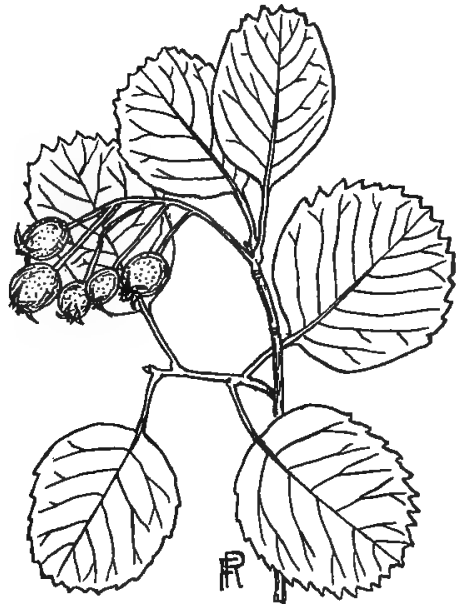

Fig. 56.-June BerRy (Amelanchier alnifolia). $\times \frac{1}{2}$. 


\section{Genus I3. AMELANChIER, June Berry, Service Berry}

Seven species of this genus are recorded from the state, all but the following being shrubs.

Ia. Small tree or shrub on hillsides or in canyons; the fruit a pome; leaves toothed only near the apex.

Amelanchier alnifolia Nutt.

\section{Genus I4. CRATAEGUS, ThORNAPPLE}

Trees or shrubs with stout spines and handsome white flowers; growing along streams in the foothill region. Fruit, red, black, brown or orange.

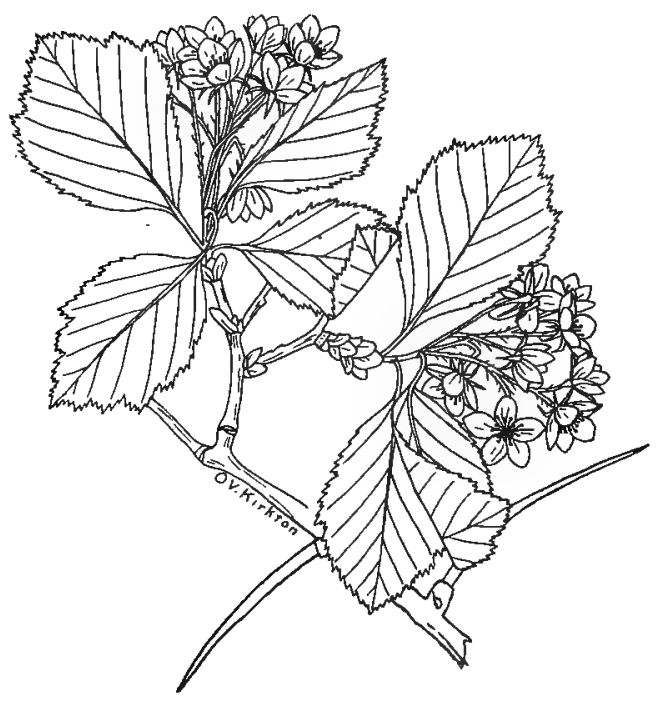

Fig. 57.-Cotorado Thornapple (Crataegus coloradensis). $\times \frac{1}{2}$.

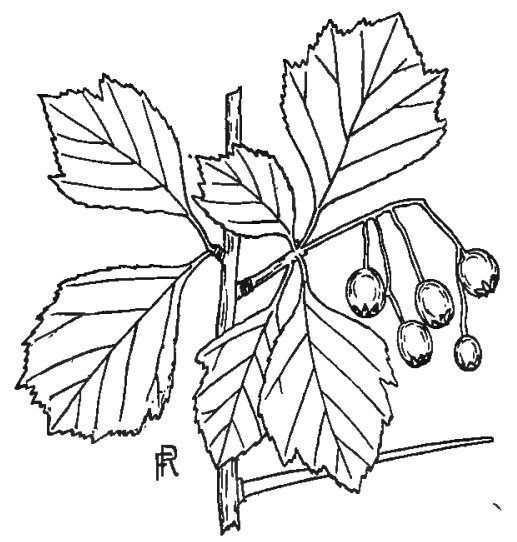

Fig. 58.-St. I.AWRence Thornapple (Cratuegus laurentiana). $\times \frac{1}{2}$.

Ia. Spines long, 3 to $8 \mathrm{~cm}$. ( 1 to 3 in.).

(2)

Ib. Spines short, about $2 \mathrm{~cm}$. ( $\frac{3}{4} \mathrm{in}$.).

(7)

2a. Anthers pink or crimson.

(3)

2b. Anthers white or cream. 

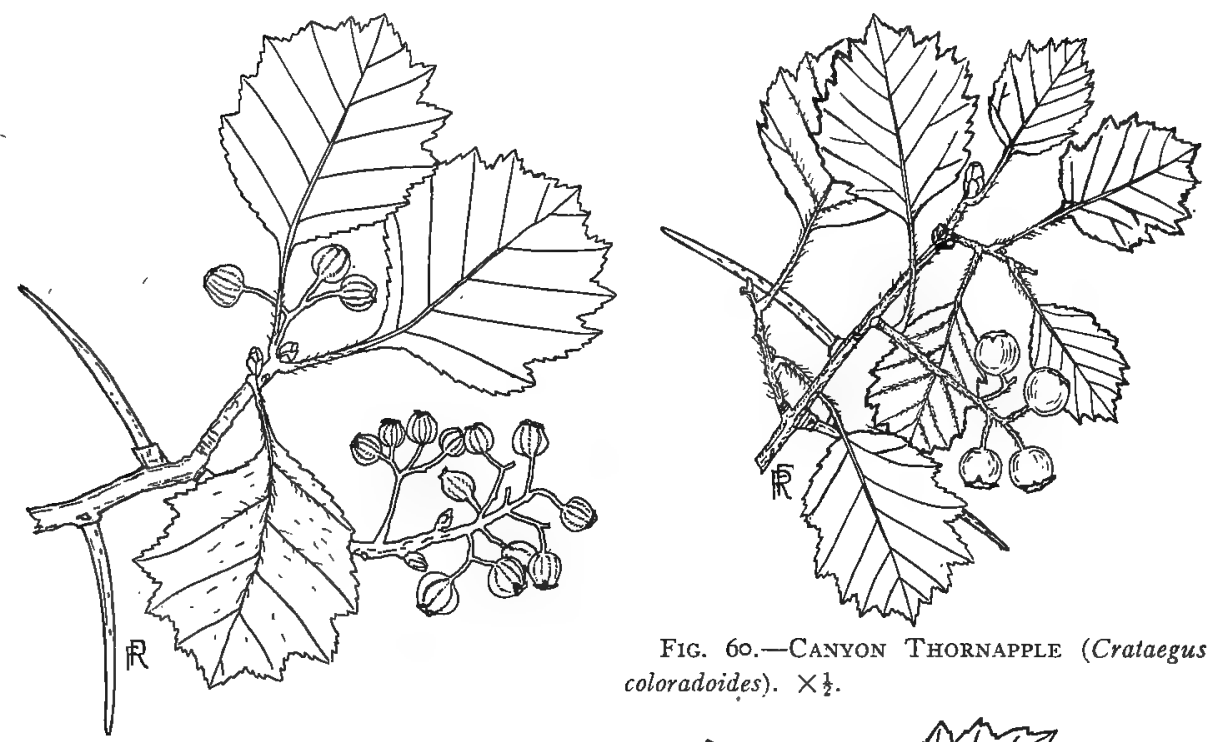

Fig. 60.-Canyon Thornapple (Crataegus coloradoides). $\times \frac{1}{2}$.

Fig. 59.-Thick-telaved Thornapple (Cralaegus doddsii). $\times \frac{1}{2}$.

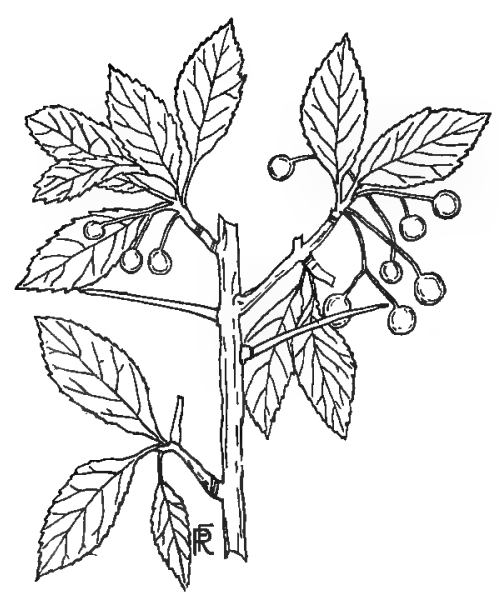

Fig. 6I.-Small-Leaved Thornapple (Crataegus saligna). $\times \frac{1}{2}$.

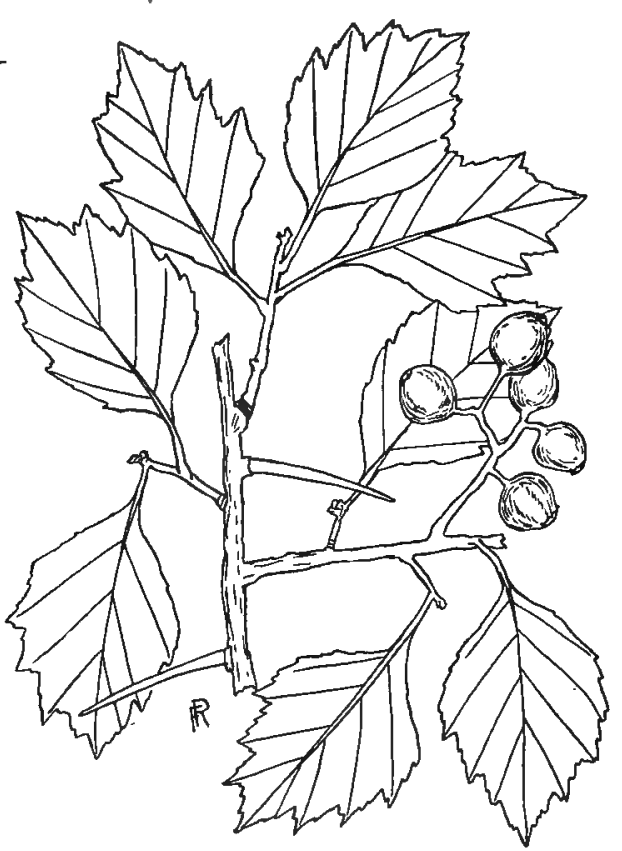

Fig. 62.-Shiny-Leaved Thornapple (Crataegus cerronis). $\times \frac{1}{2}$. 
3a. Pedicels glabrous.

Crataegus cerronis A. Nels. "Shiny-leaved Thornapple"

3b. Pedicels somewhat villous; leaves broadly ovate. Crataegus coloradensis A. Nels. "Colorado Thornapple"

3c. Pedicels densely villous at flowering time; becoming nearly glabrous; leaves obovate, wedge-shaped at base.

Crataegus laurentiana Sarg. "St. Lawrence Thornapple"

4a. Shoots becoming glabrous or nearly so at close of first year; leaf serrations glandular.

4b. Shoots villous or pubescent throughout the first year; leaf serrations not glandular.

5a. Leaves at maturity with scattered villous pubescence below, especially on the veins; fruit dark red.

Crataegus doddsii Ramaley.

"Thick-leaved Thornapple"

6a. Petiole about the length of the blade; leaf-apex often obtuse.

Crataegus occidentalis Britt. "Western Thornapple"

6b. Petiole about $\frac{1}{3}$ to $\frac{1}{2}$ the length of the blade; leaf-apex often somewhat truncate.

Crataegus coloradoides Ramaley. "Canyon Thornapple"

7a. Leaves ovate, simply serrate or crenate, 2 to $4 \mathrm{~cm}$. broad. Crataegus rivularis Nutt. "River-bank Thornapple"

7b. Leaves lanceolate, serrate, sometimes obscurely lobed; only I to $2 \mathrm{~cm}$. broad (generally about $\mathrm{I} .5 \mathrm{~cm}$.).

Crataegus saligna Greene. "Small-leaved Thornapple"

\section{Genus i 5. PRUNUS, Plum and Cherry}

Four species of Prunus are recognized as occurring in Colorado. One is the common wild plum so abundant at canyon mouths in the foothills; the others are cherries. Of the latter, Prunus besseyi is a dwarf species, often a mere trailing or prostrate shrub.

ra. Flowers and fruits in long racemes; fruit black when ripe.

Prunus melanocarpa (A. Nels.) Rydb. "Choke Cherry"

Ib. Flowers and fruits in short umbels or corymbs.

2a. Leaves bright green and shining above; fruit red, 5 to $7 \mathrm{~mm}$. (about 1 in.). in diameter. Prunus pennsylvanica Linn. f. "Wild Red Cherry"

2b. Leaves dull green above; fruit 20 to $25 \mathrm{~mm}$. ( $\frac{3}{4}$ to $\mathrm{I}$ in.) in diameter.

Prunus americana Marsh. "Wild Plum" 


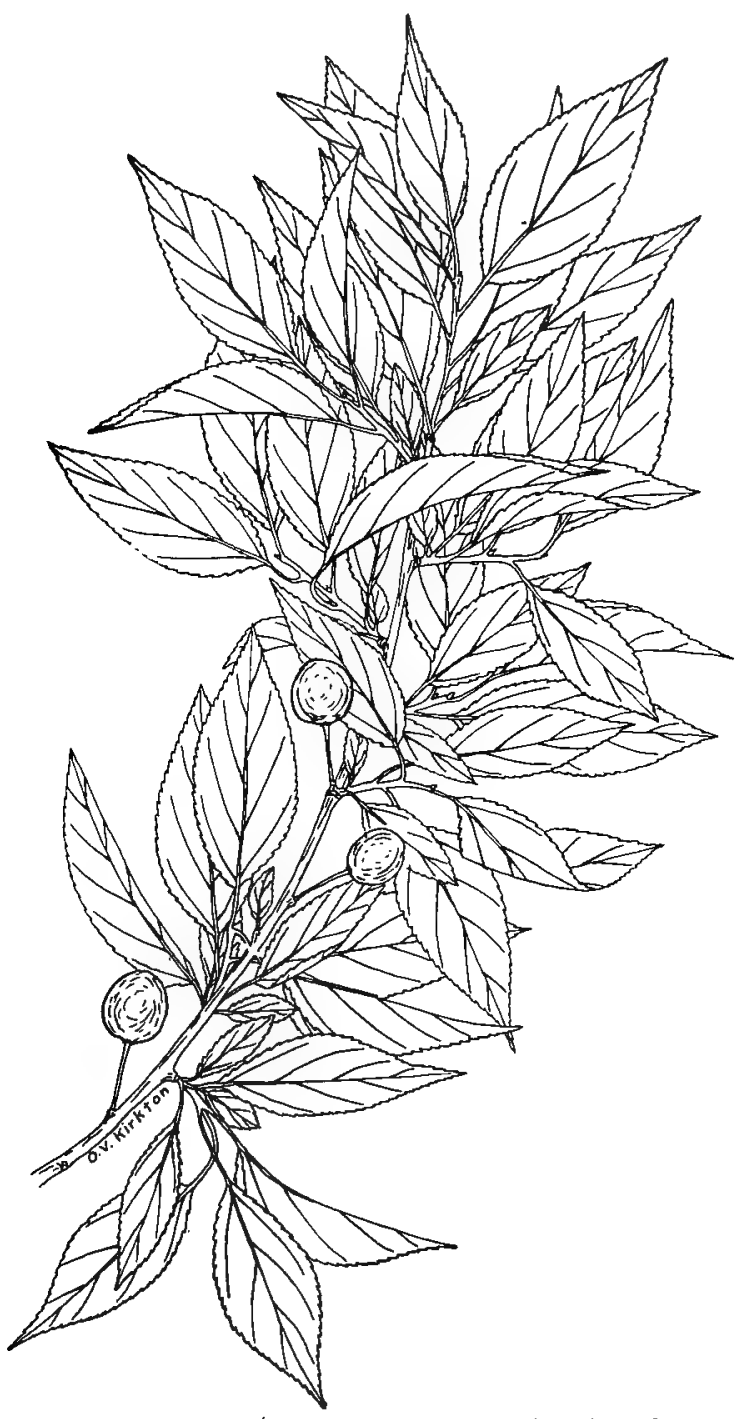

Fig. 63.-WILd Plum (Prumus americana). $\times \frac{1}{2}$ 


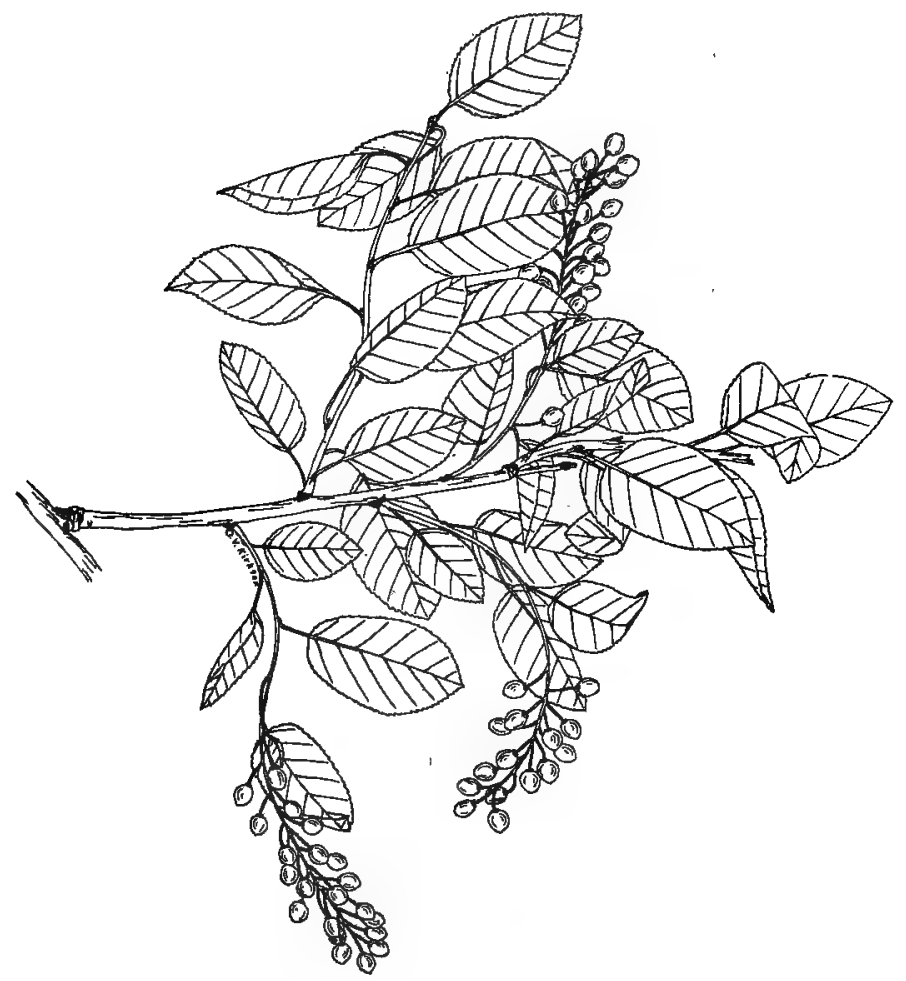

Fig. 64.-Chore CherRy (Prumus melanocarpa). $\times \frac{1}{3}$

Genus I6. ROBINIA, Locust

The native Colorado locust is closely related to the common black locust or yellow locust now so often planted for posts and railway ties.

Ia. Small tree or shrub with pinnately compound leaves and pink, pea-like flowers, producing many-seeded pods. Along streams in southern part of state.

Robinia neo-mexicana A. Gray. "Pink Locust"

\section{Genus i7. ACER, Maples and Box-ELder}

ra. Leaves compound, of 3,5 or 7 leaflets.

Acer interior Britt. "Box-Elder"

Ib. Leaves simple; palmately veined.

3a. Leaves longer than broad; generally three-lobed, margins distinctly serrate.

Acer glabrum Torr.

2b. Leaves broader than long; three to five-lobed; margins not serrate.

"Rocky Mountain Maple" Acer grandidentatum Nutt. "Mountain Sugar Maple" 


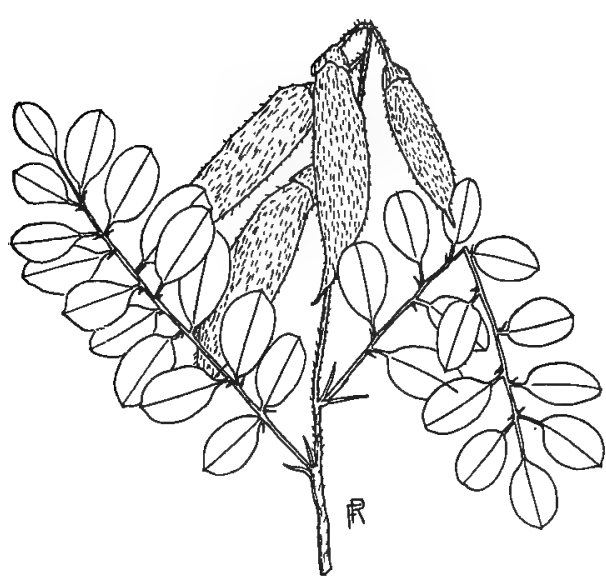

Fig. 65.-Pink Locust (Robinia neo-mexicana). $\times \frac{1}{3}$.

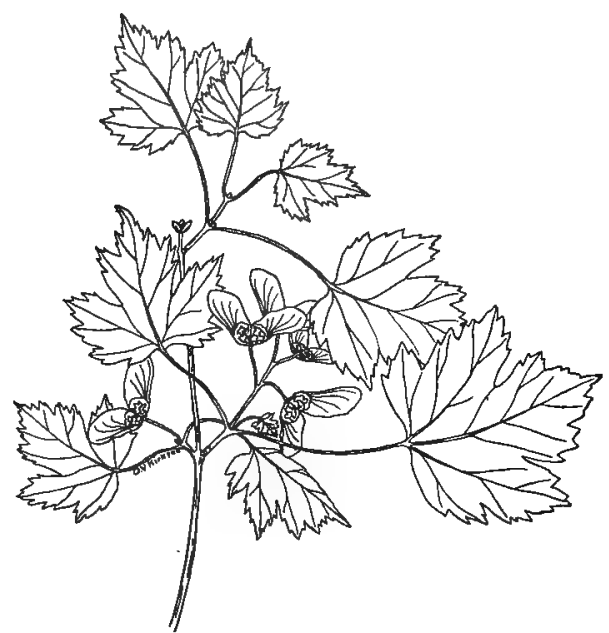

Fig. 66.-Rocky Mountain M glabrum). $\times \frac{1}{3}$.

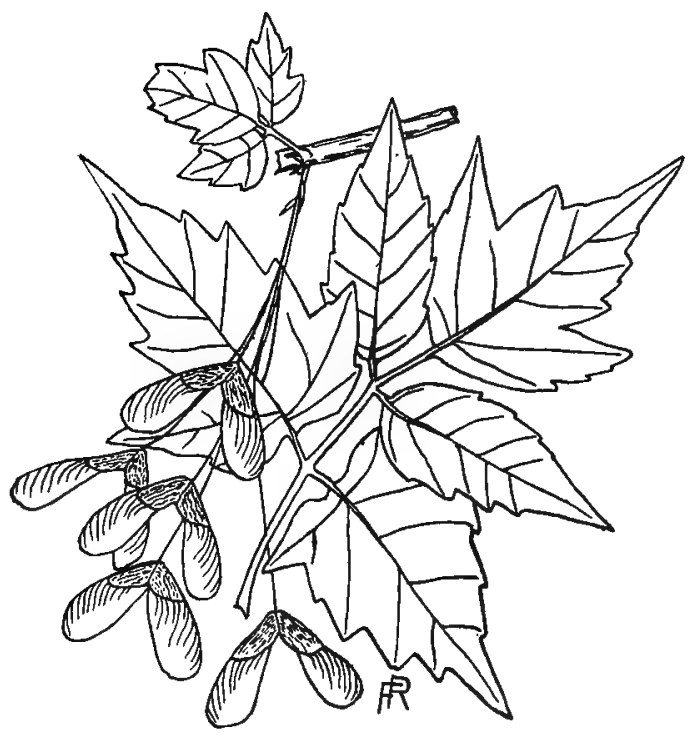

Fig. 67.-Box Elder (Acer interior). $\times \frac{1}{2}$.

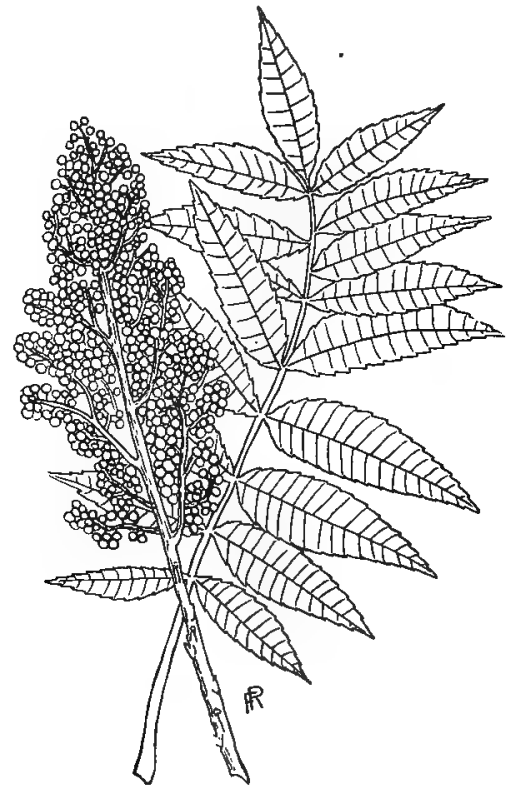

Fig. 68.-Suniac (Rhus glabra). $\times \frac{1}{3}$. 


\section{Genus I8. RHUS, SUMAC}

This genus is represented in Colorado by Rhus rydbergii, the western poison ivy and Rhus trilobata, the common "skunk bush," in addition to the following species.

ra. Usually a shrub but often tree-like at canyon mouths in rich, well-watered soil. Leaves compound, of numerous pointed leaflets; turning to red or crimson in autumn.

Rhus glabra Linn.

"Sumac"

\section{Genus I9. RHAMNUS, BUCKTHORN}

Ia. Tree of western Colorado and westward; elliptical leaves; small greenish flowers; black berry-like fruits. The bark has medicinal properties.

Rhamnus purshiana DC. "Cascara sagrada"

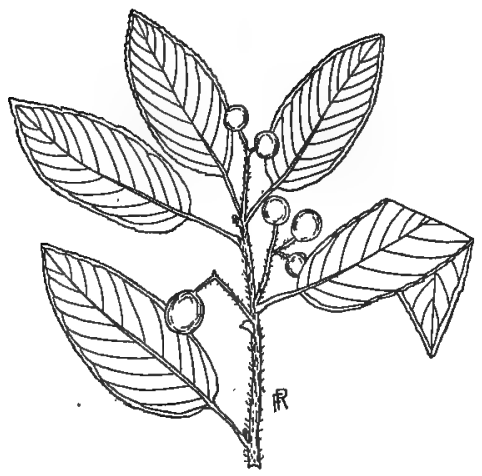

Fig. 69.-Cascara Sagrada (Rhomnus burshiana). $\times \frac{1}{3}$.

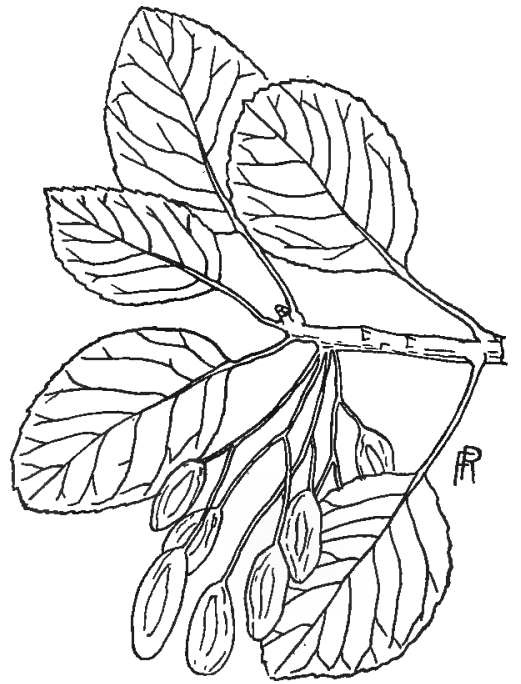

FIG. 70.-ASH (Fraxinus anomala). $\times \frac{1}{2}$.

Genus 20. FRAXINUS, AsH

Related to the "white ash" and "green ash" so commonly planted for shade. The Colorado species has the typical flower and fruit structure of the ash but the leaf is not usually compound.

Ia. Leaf simple, or occasionally with two or three leaflets; fruit a winged samara. Occurring in canyons of the southwestern part of the state.

Fraxinus anomala Torr. 


\section{Partial List of Books and Special Articles Dealing with Colorado Trees}

Ashe, W. W., "New North American Plants; Some New Species of Crataegus," Ann. Rep. No. 24, N. C. Coll. of Agric. and Mech. Arts, June 30, $190 \mathrm{r}$.

Bennett, Mrs. Cora, "List of Colorado Trees," Plant World, Vol. XI, p. 66, I9o8.

Britton, N. L., North Anterican Trees, Pp. I-894, New York, igo8.

Clements, Frederic E., "Formation and Succession Herbaria," University of Nebrasha Studies, Vol. IV, pp. 329-355.

Cockerell, T. D. A., "The Genus Crataegus in Colorado," University of Colorado Studies, Vol. V, pp. $4 \mathrm{I}-45,1907$.

Cooper, W. S., "Alpine Vegetation in the Vicinity of Long's Peak, Colo.," Botanical Gazette, Vol. XLV, pp. 3'9-33.3, I908.

Coulter, JoHn M., Manual of Botany of the Rocky Mountain Region, New York ( 1882 ?), pp. I-453.

Dodys, GIDEON S., "Studies of Mesa and Foothill Vegetation; Geology and Physiography of the Mesas," University of Colorado Studies, Vol. VI, pp. I I-I9, Igo8.

Dodds, Gideon S., AND Robbins, W. W., "Studies of Mesa and Foothill Vegetation; Distribution of Conifers on the Mesas," Universily of Colorado Studies, Vol. VI, pp. $3 \mathrm{I}-36,1908$.

Ensign, Edgar T., "Report of Forest Conditions in the Rocky Mountains," Bull. No. 2, Forestry Division, Department of Agriculture (2d ed.), pp. IfI-I53, 1889.

Gannett, Henry, "The Forests of the United States," Igth Annual Report U. S. Geol. Survey, Part V, pp. 1-26, 1897-98; 20th Annual Report, Pp. I-38, I898-99; 2Ist Annual Report, pp. I3-15, I899-19oo.

JACK, JoHN G., "List of Trees and Shrubs Observed in the Pike's Peak, Plum Creek and South Platte Reserves," 2oth Annual Report, U. S. Geol. Survey, Part V, pp. I09-II5, I898-99; "Pike's Peak, Plum Creek and South Platte Reserves," pp. 39-108, same publication.

Milis, Enos A., And Stone, W. G. M., Forest and Exotic Trees of Colorado (Pamphlet), Denver, I905.

Nelson, Aven, Analytical Key to Some of the Common Flowering Plants of the Rochy Mountain Region, pp. I-94, New York, I902.

—_, "Plantae Andrewsii," Proc. Biol. Society Wash., Vol. XVII, pp. I73-180, I904.

Ramaley, Francis, "Remarks on the Distribution of Plants in Colorado East of the Divide," Postelsia; Yearbook of the Minn. Seaside Station, Pp. 2I-53, IgoI. , "The Silva of Colorado; Trees of the Pine Family," University of Colorado Studies, Vol. IV, pp. Iog-I22, I907; "The Silva of Colorado; Poplars, Aspens and Cottonwoods," Vol. IV, pp. 187-197, I907; "The Silva of Colorado; Woody Plants of Boulder County," Vol. V, pp. 47-63, 1907 .

-_ - "Plant Zones in the Rocky Mountains of Colorado," Science (New Series), Vol. XXVI, pp. 642, 643, 1907.

- _ " "Botany of Northeastern Larimer County, Colorado," University of Colorado Studies, Vol. V, pp. II9-I3I, Igo8.

_- "Studies of Mesa and Foothill Vegetation, Climatology of Mesas," Unizersity of Colorado Studies, Vol. VI, Pp. I9-3I, I908.

- -, "New Colorado Species of Crataegus," Botanical Gazette, Vol. XLVI, pp. $3^{8 \mathrm{I}-3^{8}} \mathrm{~s}_{4}$ I908. 
Ramaley, Francis, and Dodds, G. S., "Two Imperfectly Known Species of Cralaegus,"

Bull. Torrey Botanical Chub, Vol. XXXV, pp. $5^{8 \mathrm{I}-58}$, I908.
, AND RoBbINs, W. W., "Studies in Lake and Streamside Vegetation; Redrock Lake near Ward, Colo.," University of Colorado Studies, Vol. VI, pp. I33-r68, Igog.

Ronbins, W. W., "Studies of Mesa and Foothill Vegetation; Deciduous Trees and Shrubs of the Mesas," University of Colorado Studies, Vol. VI, pp. 36-47, Igo8.

- AND Dodds, G. S., "Studies in Mesa and Foothill Vegetation; Distribution of Conifers on the Mesas," University of Colorado Studies, Vol. VI, pp. 3I-36, I908.

Rothrock, J. T., "Notes on Colorado," U. S. Geog. Surv. West of the Iooth Meridian (Wheeler Report), Vol. VI, pp. I-I5.

RydberG, P. A., "The Oaks of the Continental Divide North of Mexico," Bull. N. Y. Botanical Garden, rgor.

- Flora of Colorado, Bull. ıoo, Colo. Agric. Coll. Exper. Sta., pp. I-447, Ft. Collins, Colo.,' Igo6.

Sargent, Charles S., Report on the Forests of North America; toth Census of the United States, Vol. IX, Washington, 1884.

- Manual of the Trees of North America, pp. I826, Boston, I905.

Schneider, E. C., "The Distribution of Woody Plants in the Pikes' Peak Region," Colorado College Publications (Science Series), Vol. XII, pp. I37-I 70, I909.

Young, RoBert T., "Forest Formations of Boulder County, Colorado," Botanical Cazelte, Vol. XLVI, Pp. 32I-352, 1907. 


\section{ALPHABETICAL INDEX OF WILD FLOWERS AND TREES}

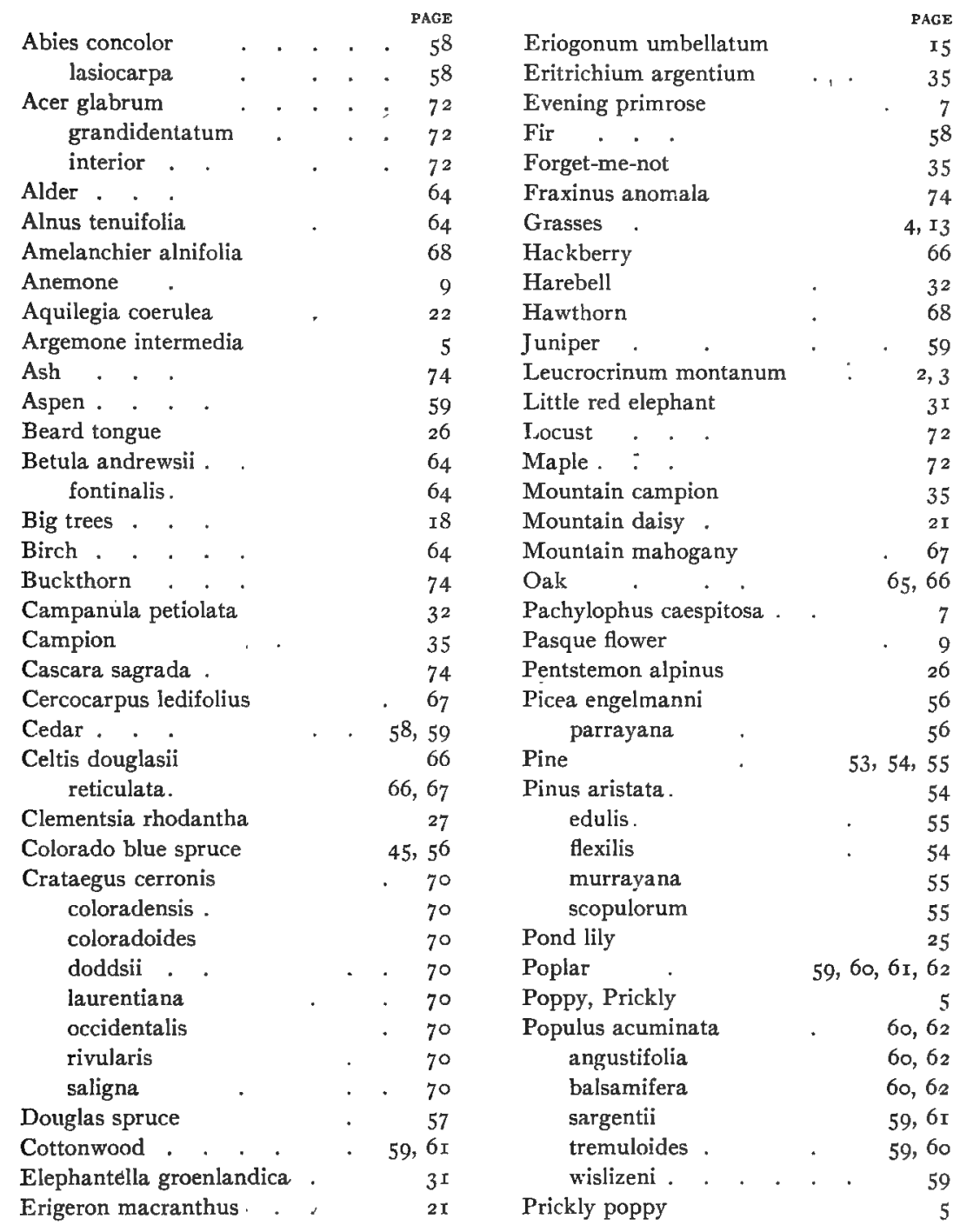


Primrose, Evening . .

PAGE

Prunus americana

7

melanocarpa.

$70,7 \mathrm{I}$

pennsylvanica

70,72

70

Pseudotsuga mucronat $\vec{a} \quad$. 57

Pulsatilla hirsutissima

Quaking aspen .

Quercus gambellii

9

9
60

Quercus leptophylla

nitescens

utahensis. .

65

66

65

Red orpine .

27

Rhamnus purshiana .

Rhus glabra.

74

Rohinia neo-mexicana

73,74

Rydbergia grandiflora

72,73

34

Sabina monosperma .

59

scopulorum . . 59

utahensis. . . . $\quad 5^{8}$ 





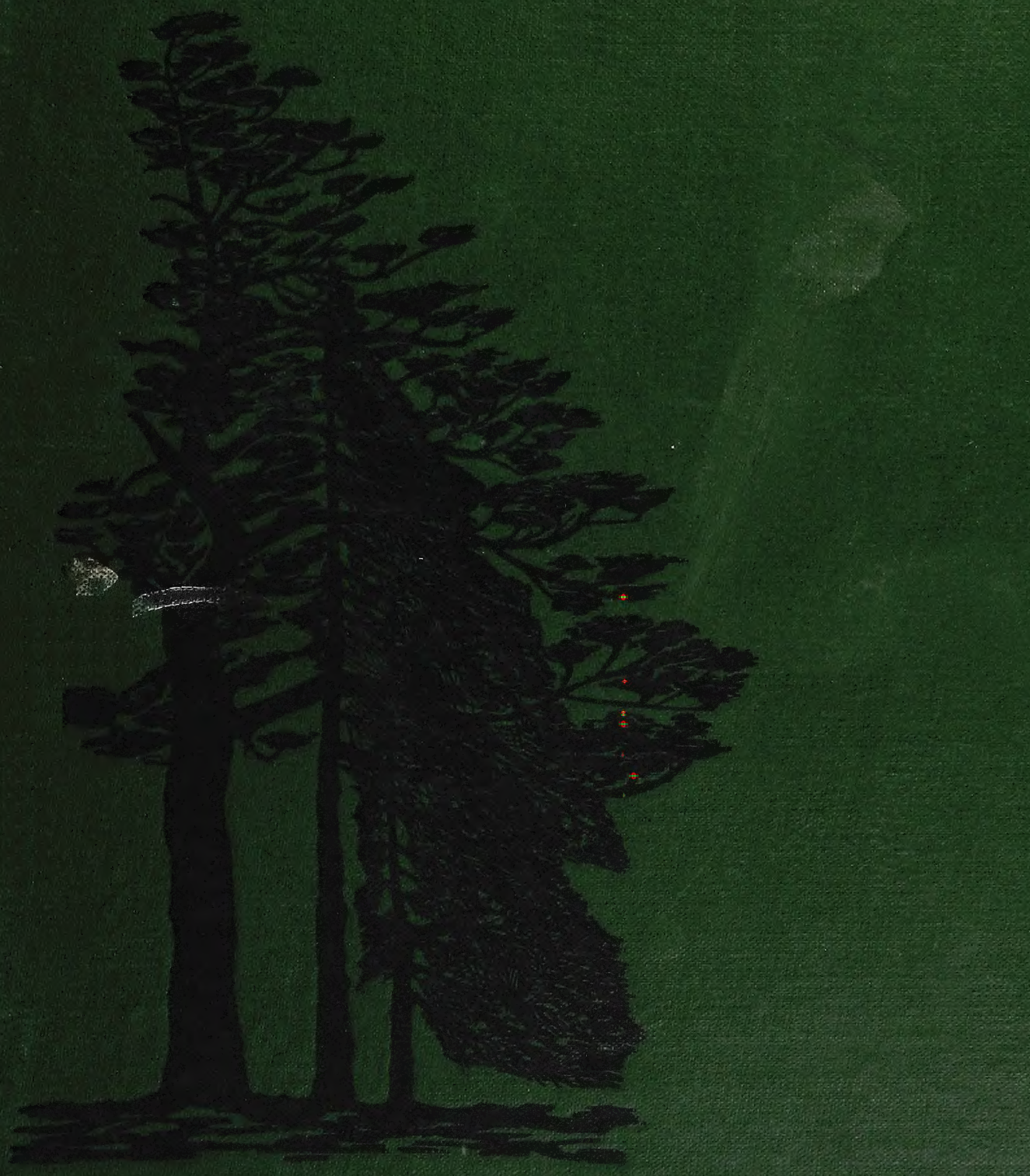

